This manuscript is a preprint and will be submitted to the journal of Petroleum Geoscience, Geological Society of London. This manuscript has not undergone peer review. Subsequent versions of this manuscript may have different content. If accepted, the final peer-reviewed version of this manuscript will be available via the 'Peer-reviewed Publication' DOI link on the right-hand side of this webpage. Please feel free to contact any of the authors directly to comment on the manuscript. 


\title{
Evolution of a sand-rich submarine channel-lobe system and impact of mass-transport and transitional flow deposits on reservoir heterogeneity: Magnus Field, northern North Sea
}

Michael J. Steventon ${ }^{1 *}$, Christopher A-L. Jackson ${ }^{1}$, Howard D. Johnson ${ }^{1}$, David M. Hodgson ${ }^{2}$, Sean Kelly ${ }^{3}$, Jenny Omma ${ }^{4}$, Christine Gopon ${ }^{4}$, Christopher Stevenson ${ }^{5} \&$ Peter Fitch $^{1}$

${ }^{1}$ Basins Research Group (BRG), Department of Earth Science \& Engineering, Imperial College, Prince Consort Road, London, SW7 2BP

${ }^{2}$ School of Earth and Environment, University of Leeds, Leeds, LS2 9JT

${ }^{3}$ EnQuest PLC, Annan House, Palmerston Road, Aberdeen, AB11 5QP

${ }^{4}$ Rocktype Ltd, 87 Divinity Road, Oxford, OX4 1LN

${ }^{5}$ School of Earth, Ocean and Ecological Sciences, University of Liverpool, Liverpool, L69 3GP

*Correspondence: m.steventon@shell.com

Running header: Magnus Field deposits

\begin{abstract}
The geometry, distribution, and rock properties (i.e. porosity and permeability) of turbidite reservoirs, and the processes associated with turbidity current deposition, are relatively well known. However, less attention has been given to the equivalent properties resulting from laminar sediment gravity-flow deposition, with most research limited to cogenetic turbidite-debrites (i.e. transitional flow deposits) or subsurface studies that focus predominantly on seismic-scale mass-transport deposits (MTDs). Thus, we have a limited understanding of sub-seismic MTDs ability to act as hydraulic seals and their effect on hydrocarbon production, and/or carbon storage and sequestration. We investigate the gap between seismically resolvable and sub-seismic MTDs and transitional flow deposits on long-term reservoir performance in this analysis of a small ( $<10 \mathrm{~km}$ radius submarine fan system), Late Jurassic, sandstonerich stacked turbidite reservoir (Magnus Field, northern North Sea), which is supported by a relatively long (c. 37 years) and well-documented production history. We use core, petrophysical logs, pore fluid pressure, quantitative evaluation of minerals by scanning electron microscopy (QEMSCAN), and 3D seismic-reflection datasets to quantify the type and distribution of sedimentary facies and rock properties. A range of sediment gravity deposits are recognised: (i) thick-/thin- bedded, structureless and structured turbidite sandstone, constituting the primary productive reservoir facies (c. porosity $=$ $22 \%$, permeability $=500 \mathrm{mD}$ ), (ii) a range of transitional flow deposits, and (iii) heterogeneous mudrich sandstone interpreted as debrites (c. porosity $=<10 \%$, volume of clay $=35 \%$, up to $18 \mathrm{~m}$ thick). Results from this study show that over the production timescale of the Magnus Field, debrites act as
\end{abstract}


barriers, compartmentalising the reservoir into two parts (upper and lower reservoir), and transitional flow deposits act as baffles, impacting sweep efficiency during production. Prediction of the rock properties of laminar and transitional flow deposits, and their effect on reservoir distribution, has important implications for: (i) exploration play concepts, particularly in predicting the seal potential of MTDs, (ii) pore pressure prediction within turbidite reservoirs, and (iii) the impact of transitional flow deposits on reservoir quality and sweep efficiency.

Keywords: deep-water fan/lobe, mass-transport complex (MTC), megabeds, hybrid event beds (HEBs), banded beds, subsurface fluid flow, reservoir characterisation, reservoir quality. 
Sand-rich submarine lobes are small to moderate sized systems (c. 5-100 km radius), typically fed by point-source canyons or shelf failure, and characterised by a high percentage (c. 70\%) of sand-grade material (e.g. Mutti \& Normark 1987; Reading \& Richards 1994; Mattern 2005). Sand-rich channellobe systems form high-quality reservoirs in many basins (e.g. the North Sea, Gres d'Annot, and Tabernas basins), and the stratigraphic architecture of their turbidite deposits have been extensively studied (e.g. Piper \& Normark 1983; Reading \& Richards 1994; Kendrick 1998; Prather 2003). Spatial understanding of the inter- and intra-reservoir heterogeneities within these systems is critical for reservoir evaluation (e.g. Garland et al. 1999; Drinkwater \& Pickering 2001; Hodgson 2009). In this study, we document sub-seismic mass-transport deposits (MTDs) and transitional flow deposits (i.e. hybrid, banded, and slurry beds), highlighting their impact on hydrocarbon fluid flow and the stratigraphic evolution of a sand-rich lobe system.

\section{MTDs and petroleum systems}

MTDs are the product of creep, slide, slump, and debris flow processes (see Dott 1963; Nardin 1979; Coleman \& Prior 1988; Weimer 1989). MTDs are typically sourced from slope or shelf-edge environments when the component of downslope shear stress exceeds the shear strength of in-situ sediment (Hampton et al 1996). MTDs can be composed of a mixture of debrites and deformed sediments, derived from the headwall, or from entrainment of the substrate during emplacement (e.g. Pickering \& Corregidor 2005; Flint et al. 2007; Tripsanas et al. 2008). The geometry, aerial extent, and thickness of MTDs is highly variable, ranging from $<10 \mathrm{~m}$ thick (e.g. Auchter et al. 2016) to $>100 \mathrm{~m}$ thick (e.g. Moscardelli et al. 2006). Here, we make a distinction between (1) small-scale MTDs resulting from single failure episodes and typically $<10 \mathrm{~m}$ thick (hence usually sub-seismic, but covering most core, well log and outcrop scales), and (2) large-scale mass-transport complexes (MTCs) comprising of multiple genetically related mass-transport and sediment gravity flow deposits, usually $10 \mathrm{~s}-100 \mathrm{~s} \mathrm{~m}$ thick (within seismic resolution), and often identified as single seismic-stratigraphic units (Weimer 1989; Beaubouef \& Friedmann 2000; Ortiz-Karpf et al. 2016).

In petroleum systems, MTDs can act as seals (e.g. Day-Stirrat et al. 2013; Cardona et al. 2016) and less commonly as reservoirs (e.g. Jennette et al. 2000; Welbon et al. 2007; Meckel 2011). MTDs can form seals through shear deformation along a basal shear zone (BSZ), resulting in alignment of clay fabrics and increasing bulk rock density, thereby significantly reducing permeability (Dugan 2012; Day-Stirrat et al. 2013; Wu et al. 2019). Fluid migration can be focused along the BSZ (e.g. Sun et al. 2017), or they can form fluid bypass conduits (e.g. Gamboa \& Alves 2015; Sun \& Alves 2020). MTDs are also linked to zones of anomalously high fluid pressures, due to either shallow overpressure generated by rapid sedimentation, or shallow gas accumulations where MTDs act as capillary seals (Osborne \& 
Swarbrick 1997). The irregular top surfaces relief of large MTDs can influence behaviour of subsequence sediment gravity flows and therefore, the distribution and geometry of overlying turbidite reservoirs, which in some cases can create stratigraphic traps (e.g. Armitage et al. 2009; Jackson \& Johnson 2009; Dykstra et al. 2011; Ortiz-Karpf et al. 2015; Kneller et al. 2016; Bell et al. 2018, Fig. 1a, b). Most work has focused on seismic-scale, sealing-MTDs, with only limited consideration given to the spatial variability of their rock properties (see Yamamoto \& Sawyer 2012). Many studies use well data from shallowly buried $(<1 \mathrm{~km})$ MTDs, with a focus on the Gulf of Mexico (e.g. Flemings et al. 2008; Dugan 2012; Sawyer et al. 2012; Day-Stirrat et al. 2013; Wu et al. 2019). These types of studies are useful when considering the controls and location of shallow fluid flow within basins, or when analysing the failure mechanisms of submarine slopes; however, they are less relevant to understanding how MTDs may act as hydrocarbon seals and baffles within deeply buried reservoirs. Here, we focus on MTDs that act as intra-reservoir seals, either in the form of barriers to fluid flow, forming separate reservoir compartments (e.g. Beaubouef \& Abreu 2010; Algar et al. 2011), or as more localised baffles in conjunction with transitional flow deposits (e.g. hybrid beds) thereby contributing to reservoir heterogeneity and a reduction in effective permeability (e.g. O'Connor \& Walker 1993; Garland et al. 1999; McCaffrey \& Kneller 2001; Haughton et al. 2003).

\section{Seal evaluation and MTDs}

Any evaluation of seal potential needs to focus on three properties: (i) capacity, which is related to minimum capillary entry pressure and controlled by pore-throat characteristics, most notably size and connectivity, (ii) integrity, which is related to rock ductility and tendency to fracture during deformation, and (iii) geometry, which is related to thickness, form, and aerial extent of the unit, and is controlled by depositional environment (Downey 1984; Kaldi \& Atkinson 1997). Evidence that MTDs can act as seals is observed at several scales.. First, seismic-scale studies also show that structural fabrics surrounding large ( 0.5-5 km wide) rafted blocks can decrease seal integrity (Alves et al. 2014; Gamboa $\&$ Alves 2015; Steventon et al. 2019). Seismic-scale sealing MTDs are evident where gas-related bright spots are located directly beneath MTDs (e.g. Berndt et al. 2003; Bünz et al. 2003; Berndt et al. 2012; Sun et al. 2017), and where there is a lack of gas-escape structures (e.g. pockmarks) directly above these deposits (e.g. Sarkar et al. 2012; Riboulot et al. 2013). Second, at the borehole-scale, analysis of petrophysical well logs, pore fluid pressure, shear deformation, and capillary pressures characteristics all point to MTDs having relatively low permeability (Flemings et al. 2008; Dugan 2012; Yamamoto \& Sawyer 2012; Day-Stirrat et al. 2013; Cardona et al. 2016; Wu et al. 2019) (Fig. 1c). 


\section{Reservoir evaluation and transitional flow deposits}

In relation to reservoir evaluation, small-scale MTDs, thin-bedded turbidites, and transitional flow deposits (e.g. linked turbidite-debrite beds, hybrid beds, and banded beds; see Lowe \& Guy 2000; Haughton et al. 2003; Talling et al. 2004) can impart significant heterogeneity within otherwise highquality turbidite reservoirs. This type of bed-scale heterogeneity is often below seismic and sometimes conventional well log scales (i.e. cm-dm-scale) and requires core data for effective analysis. Thinbedded turbidites or simply "thin beds", have received much attention in both outcrop (e.g. Mutti 1977; Stow \& Piper 1984; Walker 1985) and the subsurface (e.g. Kendrick 1998; Kendrick 2000; Hansen et al. 2017), typically associated with submarine levee, lobe fringe, and basinfloor settings, or sediment bypass-dominated zones (Stevenson et al. 2015). Thin-bedded turbidites can contribute significantly to reservoir pay where they are separated by only thin mudstones, in other cases they can be mudstonedominated and act as baffles (Passey et al. 2006). However, less attention has been given to the role of transitional flow deposits (see Haughton et al. 2003; Lowe et al. 2003; Talling et al. 2004). Analysis of transitional flow deposits has focused on their distribution in relation to an idealised lobe complex (e.g. Hodgson 2009; Fonnesu et al. 2015; Spychala et al. 2017b) and their occurrence in confined basins (e.g. Haughton et al. 2009; Fonnesu et al. 2018; Soutter et al. 2019). Reservoir quality studies of transitional flow deposit and their impact on subsurface fluid flow are more limited (see Amy et al. 2009; Porten et al. 2016; Southern et al. 2017).

\section{Aims and significance}

Here, we aim to bridge the gap between shallowly-buried seismically-resolvable MTDs and deeplyburied sub-seismic MTDs and transitional flow deposits, by studying their distribution within an Upper Jurassic turbidite sandstone reservoir in the Magnus Field, northern North Sea (Fig. 2). The Magnus Field is a mature oilfield: discovered in 1974, with first oil production in 1983, and the start of enhanced oil recovery in 2002 (MacGregor et al. 2005). There is an estimated c.1.8 billion barrels of STOIIP, with a predicted recovery factor of 50-55\% (Shepherd et al. 1990; MacGregor et al. 2005). We aim to document the comprehensive well-bore and seismic reflection dataset, to enable a thorough analysis of the reservoir's nature, origin, and distribution of physical properties (i.e. porosity, permeability, volume of clay, density/compressional velocity), including sub-seismic MTDs and transitional flow deposits. We focus on three main objectives: (i) to capture the stratigraphic evolution of the submarine slope depositional system in the Magnus reservoir, (ii) to characterise the lateral variability of sub-seismic MTDs and assess their impact on fluid flow, and (iii) to investigate the impact of overlying transitional flow deposits on reservoir quality and fluid flow. Our study has implications for petroleum exploration 
and production, and the role of MTDs in carbon storage and sequestration projects, including predicting the distribution of deep-water reservoir-seal pairs, and understanding the impact of heterogeneities on turbidite reservoir connectivity, compartmentalisation, and pore-pressure prediction.

\section{BASIN SETTING \& STRATIGRAPHY}

\section{Structure}

The Viking Graben represents one arm of the northern North Sea trilete rift system, formed through multiple episodes of extension during the Permo-Triassic and latest Jurassic-Early Cretaceous (e.g. Badley et al. 1984; Badley et al. 1988; Yielding 1990). The East Shetland Basin comprises several halfgrabens, bound to the east by the Viking Graben and to the west by the Shetland Platform, Unst Basin, and Magnus Basin (Johns \& Andrews 1985; Lee \& Hwang 1993). The basin has undergone a complex tectono-stratigraphic history, influenced by: (i) Caledonian basement structural grains, (ii) Middle-toLate Jurassic and Early Cretaceous rifting, associated with the formation of the Viking Graben, and (iii) early Cretaceous rifting and opening of the Magnus and Møre Basins in the North Atlantic (Shepherd 1991; Gabrielsen et al. 1999; Al-Abry 2002). The post-Triassic sedimentary succession of the East Shetland Basin consists of Triassic-Jurassic tilted fault blocks, with syn-rift sedimentation transitioning from shallow marine to deep marine environments (Partington et al. 1993; Morris et al. 1999). The succession can be split into: (i) the Lower Jurassic post-rift shallow marine Dunlin Group (Jurassic sequence (J) 10), (ii) the Middle Jurassic post-rift deltaic Brent Group (J20-30), which included a period of minor fault activity recorded by a top-Rannoch unconformity, (iii) the initiation of Late Jurassic rifting during deposition of the Tarbert Formation, and (iv) deposition of the Upper Jurassic syn-rift shelfal Heather (J30-40) and deep-marine Kimmeridge Clay Formations (J60-70) (Partington et al. 1993; Morris et al. 1999; Dominguez 2007) (Fig. 2, 3, X-X ${ }^{1}$ ). These deposits were subsequently truncated during the formation of the Base Cretaceous unconformity (BCU) (Dominguez 2007). During the Cretaceous and Cenozoic, the East Shetland Basin underwent post-rift thermal subsidence, and a $\sim 3.5$ km-thick marine succession was deposited in the Magnus area (Partington et al. 1993; Ravnås \& Steel 1997).

The Magnus Field is located on the north-western limit of the East Shetland Basin, within the Penguin half-graben, bound to the north-west by the Magnus and End of the World Faults (Shepherd 1991; Thomas \& Coward 1995) (see inset maps, Fig. 2). The field lies on the crest of a tilted fault block in the footwall of the Magnus Fault, with hydrocarbons trapped by a combination of stratigraphic pinchout and truncation below the BCU (Shepherd 1991) (Fig. 3a, b). In the Magnus area, Jurassic to Cretaceous rifting led to the development of: (i) NNW-SSE and N-S-striking arrays of Late Bathonian 
early syn-rift faults, offsetting the Brent Group (pre-rift) and active during deposition of the Heather Formation, (ii) a WNW-ESE-striking array of late syn-rift faults predominantly in the Heather and Lower Kimmeridge Clay Formations, and later reactivation of the NNW-SSE-striking array of faults, and (iii) NE-SW Atlantic rifting trend in the Early Cretaceous (Fig. 3c, d) (see Al-Abry 2002). Major structures in the Magnus area include: the Brent, Magnus, and the End of the World Faults. The Brent Fault trends NNW-SSE through the Magnus area, with both the Heather and Kimmeridge Clay formations thickening into the hanging-wall of the fault, especially in the southern area of the field (Fig. $3 b, c)$. The Magnus Fault strikes NE-SW to N-S, dipping to the NW, and contains a fault scarp degradation complex in its footwall (e.g. Underhill et al. 1997). The End of the World Fault strikes NESW and dips to the NW, bounding the northern area of the Penguin half-graben (Al-Abry 2002) (Fig. 2 , inset maps).

\section{Magnus Reservoir Stratigraphy and Units}

The Magnus Field reservoir is contained within the Upper Jurassic Kimmeridge Clay Formation, comprising (bottom to top) (Fig. 2): (i) the Lower Kimmeridge Clay Formation (J50-62) composed of a turbidite and clastic injectite system (see Goodall et al. 1999), (ii) the Magnus Sandstone Member (MSM, J63-64), composed of a sand-rich turbidite system, and (iii) the Upper Kimmeridge Clay Formation (J66-70), composed of hemipelagic mudstones (Partington et al. 1993; Morris et al. 1999; Fraser et al. 2002) (Fig. 2, 3b). The MSM (the focus of this study) comprises (bottom to top) (Fig. 3e): (i) the lower MSM reservoir (MSA), (ii) a basin-wide mud-rich unit, MSB, which is related to Autissiodorensis maximum flooding surface, (iii) the upper MSM reservoir, which is subdivided in sand-rich (MSC, MSE, MSG) and mud-rich (MSD, MSF) units (MSF is marked by Iathetica re-influx), and (iv) a transition into the Upper Kimmeridge Clay Formation (MSG-MSH), marked by the Hudlestoni maximum flooding surface (Partington et al. 1993; Morris et al. 1999). Two main depositional trends are observed: (i) a lower reservoir trend (MSA) deposited within a centrally faultcontrolled depocentre, and (ii) an upper reservoir trend (MSC-H) with a southern depocentre in the footwall of the Brent Fault, and a northern depocentre onlapping the Brent Fault footwall high (Fig. 2) (Ravnås \& Steel 1997; Morris et al. 1999; Al-Abry 2002). 


\section{DATA \& METHODS}

This study utilised a 3D seismic-reflection survey and 83 wells, containing petrophysical well logs, biostratigraphic tops, and fluid pore pressure data (see Supplementary Material 1). This included 33 wells with core photos, of which 5 were available for physical core logging (see Fig. 2a for locations).

\section{Core and wireline petrophysics}

Detailed sedimentological core logging $(1: 10$ scale, i.e. $1 \mathrm{~m}=10 \mathrm{~cm})$ of the MSB and surrounding lower (MSA) and upper (MSC) MSM reservoir units was undertaken on five wells, covering a combined stratigraphic thickness of $238.5 \mathrm{~m}$ (see Fig. 2 for well locations). Data collection comprised lithology, grain-size, bed thickness, type of bed contacts, and primary sedimentary and soft sediment deformational structures. QEMSCAN ${ }^{\circ}$ (quantitative evaluation of minerals by scanning electron microscopy) was used to quantify the grain size and shape, textural information, mineralogy, and porosity distribution for 14 core samples from well 211/12a-M16, located in the central area of the field (Fig. 2a). The QEMSCAN platform is a scanning electron microscope (SEM) with energy dispersive $\mathrm{x}$-ray (EDS) detectors and provides automated petrographic quantification of spatially resolved compositional and textural data. For this study, QEMSCAN data were collected by Rocktype Ltd using a QEMSCAN® WellSite instrument (Aspex Extreme Scanning Electron Microscope with 5030 Bruker EDS detectors) using the FieldScan mode at $15 \mathrm{kV}$ beam energy and $10 \mu \mathrm{m}$ stepping interval. Details of the microscope set-up can be found in Supplementary Material 2. QEMSCAN samples (QM1 to QM14) were taken from reservoir units MSA, MSB, MSC, and MSE (see Fig. 4).

In addition to physical core, a full suite of wireline logs, pressure, and core analysis data were available (see Supplementary Material 1). Core plug measurements of porosity, horizontal permeability $(\mathrm{Kh})$ and vertical permeability $(\mathrm{Kv})$ were used to define flow units and potential seals in the reservoir. Fluid pressure data (repeat formation tests) were also used to identify internal pressure breaks within the reservoir, which may reflect the presence of structural or stratigraphic barriers. Well log-based reservoir zonation and correlation of maximum flooding surfaces to subdivide the primary Magnus reservoir units (MSA-H) was guided by biostratigraphic reports from EnQuest and BP, along with published biostratigraphic schemes (see Partington et al. 1993; Morris et al. 1999, Supplementary Material 1).

\section{Seismic interpretation}

The 3D-pre-stack depth migrated seismic-reflection (ocean bottom cable) survey used in this study covers a $c .178 \mathrm{~km}^{2}$ area, imaging the tilted fault block containing the Magnus Field. The data are SEG reverse polarity (i.e. European polarity, with an increase in acoustic impedance $=$ trough), zero-phased, 
and have a lateral bin spacing of $12.5 \times 12.5 \mathrm{~m}$ and a vertical resolution (assumed to be tuning thickness, $1 / 4$ of the dominant wavelength) of $c .12 \mathrm{~m}$ at $3 \mathrm{~km}$. We interpret three seismic horizons within and surrounding the Magnus reservoir: (i) the top Heather Formation (ii) the MSA/MSB boundary, and (iii) the BCU. In addition, a coloured inversion cube was available that allowed further analysis of the lateral variability of the depositional systems (for method see Lancaster \& Whitcombe 2000).

The sand-rich reservoir sections are predominantly characterised by high-amplitude, positive (SEGreverse polarity) reflectors, related to an interface from higher density background sediments to hydrocarbon-filled lower density ("soft") sands. This equates to sand-rich reservoir zones being characterised by low acoustic impedance responses (Fig. 3a). Note amplitude maps are only extracted up to the vertical resolution of the seismic data (c. $12 \mathrm{~m})$.

\section{SEDIMENTOLOGY OF RESERVOIR SANDSTONE FACIES}

This core-based sedimentary facies analysis is focused on the MSA, MSB, and upper (MSC to MSH) units of the MSM reservoir (see Fig. 2, 3e). Seven facies types have been recognised: (i) thick-bedded sandstones (F1); (ii) thin-bedded sandstones (F2); (iii) banded heterolithic beds (F3); (iv) hybrid beds (F4); (v) heterogeneous beds (F5); (vi) mudstones (F6); and (vii) heterogeneous argillaceous beds (F7) (see Table 1, Fig.5).

\section{Turbidite deposits}

Facies 1: Thick-bedded sandstones (high-density turbidites)

Description: Fine- to coarse-grained, 0.2-1 m-thick amalgamated sandstone beds with predominantly massive or planar laminated internal features (Fig. 5, F1). Normal grading fine sand to silt is observed at bed tops, associated with current ripple and planar laminated bed tops (see Facies 2). Intercalated mudclast-rich horizons ( $\sim 0.5-2 \mathrm{~m}$ thick) (Fig. $5, \mathrm{~F} 1)$ comprise angular and/or sheared clasts $(<1-8 \mathrm{~cm}$ diameter). Intermittently preserved medium- to granule-grade sandstones (0.05-0.25 m thick), with matrix- and grain-supported intervals display erosive bases, weak normal grading, and poorly developed imbrication of quartz, lithic, and mudstone clasts (Fig. 5, F1).

Interpretation: The massive to planar laminated sandstone beds, are interpreted to have been deposited by high-density turbidity currents, with rapid deposition and bed aggradation suppressing tractional bedform development (Lowe 1982; Kneller \& Branney 1995). The basal sandstones with erosive bases 
are interpreted to be formed by tractional processes at the base of high concentration turbidity currents, with the coarsest-grained material deposited first (e.g. Walker \& Mutti 1973; Lowe 1982). Mudclastrich horizons are interpreted to represent lag deposits and represent locations dominated by sediment bypass (Stevenson et al. 2015).

\section{Facies 2: Thin-bedded sandstone (low-density turbidite)}

Description: Very fine- to fine-grained, c. 0.05-0.2 m-thick sandstone beds, showing normal grading, current ripple cross-lamination, including climbing sets, convolute lamination, and planar-parallel lamination (Fig. 5, 6k). Typically, sandstone bed bases are sharp and planar to weakly erosional, and bed tops may be sharp or normally graded. The sandstones can occur in either: (i) sets of thin bedded sandstones interbedded with mudstones ( $\sim 3 \mathrm{~m}$ set thickness), or (ii) as individual sandstone beds above high-density turbidites (Facies 1).

Interpretation: The thin-bedded structured sandstones are interpreted to have been deposited by low density turbidity currents, representing 'classical' turbidites (mainly $\mathrm{T}_{\mathrm{C}} / \mathrm{T}_{\mathrm{D} / \mathrm{E}}$ divisions) (Bouma 1964; Mutti 1977; Talling et al. 2012). The climbing ripple sets represent periods of rapid suspended sediment fallout (Fig. 6k) (Jobe et al. 2012).

\section{Transitional flow deposits}

\section{Facies 3: Banded beds}

Description: This facies is dominated by 5-35 cm-thick sandstones beds that comprise alternating dark and light, cm-scale, parallel to sub-parallel bands (Fig. 5, F3). The light bands can be planar and current ripple cross laminated and are sand-rich. Dark bands have elevated amounts of mud, and are less well sorted, but with similar maximum grain-size to the light bands (Fig. 5, F3). The upper contacts of banded beds record a sharp grain size break into an overlying mudstone.

Interpretation: Banded turbidite sandstone beds and bed divisions have been reported in the North Sea (e.g. Lowe \& Guy 2000; Haughton et al. 2009; Stevenson et al. 2020), however, the process of deposition is still under debate. Lowe \& Guy (2000) proposed a model of cyclic freezing of a near-bed plug flow, and postulate that banding forms between turbulent and laminar flow states, through variations in near-bed clay content modifying flow cohesion from low (sands-silt bands) to high (clayrich bands). However, flume tank experiments suggest flows with migrating bedforms within the upper stage plane bed flow regime can also produce banded beds (see Baas et al. 2011; Baas et al. 2016). Stevenson et al. (2020) provides a thorough review of banded turbidite sandstones, and supports the Baas model for banding of the scale observed here. 


\section{Facies 4: Hybrid beds}

Description: This facies comprises of dm-scale bipartite beds with lower fine- to medium-grained sandstone divisions, and upper argillaceous sandstone division (Fig. 5, F4), which can be described using Haughton et al.'s (2009) five-part classification scheme for a complete hybrid event bed (H1-H5). The lowermost sandstones are well-sorted and appear as either: (i) normally graded to ungraded sandstones, with basal loading structures and sheared mudstone clasts at the base, dewatering pipes, and mudclasts/chips concentrated at the top (H1) or (ii) weakly laminated to banded sandstones (Facies 3) with sharp to slightly wavy bases (H2). The overlying argillaceous sandstone division often has a sharp, loaded or variably deformed contact, sometimes with sand injection, and can contain outsized granules, highly sheared mudstones clasts, and dispersed quartz grains forming a 'starry night' appearance (H3) (Fig. 5). A sharp contact usually marks the base of thin (mm-cm-scale) parallel laminated to current ripple cross-laminated sandstones (H4), followed by a thin mudstone cap (H5) (Haughton et al. 2009)

Interpretation: Beds comprising lower sandstone divisions overlain by argillaceous sandstones are interpreted as turbidites with linked debrites (sensu Haughton et al. 2003), whereby the lower division represents a sandy turbidite and the upper argillaceous division a muddy debrite (Haughton et al. 2003; Talling et al. 2004). Overlying graded beds might represent low-density turbulent flow/wake deposits (Haughton et al. 2009). Hybrid beds may be attributed to sediment gravity flow transformation (Fisher 1983), with flow concentration increasing with runout distance of a turbidity current related to entrainment of substrate, or the partial transformation of an initial debris flow (e.g. Haughton et al. 2003; Sumner et al. 2009; Fonnesu et al. 2015; Kane et al. 2017).

\section{Facies 5: "Slurry" beds}

Description: This facies comprises beds of fine-grained, light-grey sandstones and siltstones, and darkgrey mud-rich sandstones. Individual beds are 0.25-0.7 m thick, with irregular basal contacts (Fig. 5, F5). The heterolithic alternations display soft sediment deformation, including ball and pillow structures, folded and sheared fabrics, and sheared/injected mudstone horizons (Fig. 5, F5). The beds show a similar trend to the hybrid beds, with a lower cleaner sandstone division overlain by a more argillaceous division. The beds are commonly associated with banded beds (Facies 3). However, these "slurry" beds are different to hybrid beds (Facies 4) because they show: (i) gradational changes between sand- and mud-rich facies with poorly developed debritic textures, and (ii) may be chaotic or unstructured. 
Interpretation: The chaotic sheared nature of the beds and syn-sedimentary soft sediment deformation structures suggest downslope movement of a heterolithic unit that was partially liquefied. The common occurrence above or below banded beds suggested a link between Facies 3 and 5. Therefore, we interpret the facies to represent remobilised banded sandstone beds which were transported farther downslope. This facies is similar to the "mixed slurry flows" described from the Britannia Field (Lowe \& Guy 2000), where the facies are interpreted to be deposited initially as banded beds, which were later remobilised as water-rich heterolithic mixtures (Barker et al. 2008; Eggenhuisen et al. 2010).

\section{SEDIMENTOLOGY OF MTD FACIES}

\section{Overview of the MSB unit (Facies 7)}

Facies 7 forms a 1-18 m-thick unit, which constitutes the entirety of the MSB zone (Fig. 4b, 7a). Three sub-facies are recognised, based on varying clay concentrations: (i) light coloured sand-rich (VSH<25\%, D1); (ii) grey to dark grey coloured mud-rich (VSH 25-50\%, D2-D4), and (iii) chaotic brecciated (D5) (see Table 2).

\section{Sub-facies types}

\section{Sub-facies D1 (sand-rich debrites)}

Description: Light-grey muddy sandstones, predominantly composed of fine to very coarse grained sand, with both clast- (Fig. 7c) and matrix-supported (Fig. 6a) areas. Clast are mudstone and sandstone, and sub-rounded to angular, with sheared and/or squeezed fabrics (Fig. 6a). Intact clasts of bedded sediments are smaller than Facies D2-4 $(<60 \mathrm{~cm})$ and composed of mudstones with only minor disaggregation of original begging (Fig. 7c).

\section{Sub-facies D2-4 (mud-rich debrites)}

Description: Matrix-supported sandy mudstone with "floating" grains (fine to coarse sand grade). The colour of the poorly sorted matrix varies from grey (D2-3, VSH=25-50\%) to dark grey (D4, $\mathrm{VSH}=>50 \%$ ) with increased clay content (Fig. 6b-d). A 'starry night' matrix texture is composed of predominantly granule to pebble-grade clasts of quartz, mudstones, belemnites and carbonaceous material, supported within the mudstone matrix (Fig. 5, D2-4, Fig. 6b-d). Belemnites are commonly found near the base of MSB (Fig. 7b, d). Small clasts $(<7 \mathrm{~cm}$ diameter) within the matrix are 
predominantly dark mudstones, which are either sub-rounded to angular, or sheared and aligned parallel to bedding (Fig. 4b, 6b, 7, D2-4,). Larger intact bedded and disaggregated clasts (up to $1.5 \mathrm{~m}$ thick) are observed throughout the unit (Fig. 7c, g), which are locally overturned (including Facies 1, 2, 3 and 6). Some of the larger clasts are composed of clean sandstones with angular edges (e.g. top of Fig. $7 \mathrm{~g}$ ) that are not oil stained, while others display sheared/squeezed fabrics and soft-sediment deformation (e.g. Fig. 7f). The clasts can be distinguished from regular bedded sediments by: (i) irregular, disintegrated, or sheared contacts, (ii) incorporation of poorly sorted mud-rich matrix into clasts, and (iii) juxtaposition of clasts of different facies (e.g. Fig. 7f). Structures within the unit include soft-sediment deformation, microfaulting, injections, sheared clasts oriented mostly parallel to bedding, and sheared fabrics in the matrix (Fig. 5, 6, 7).

\section{Sub-facies D5 (discordant sandstones and brecciated mudstones)}

Description: Facies D5 is composed of a chaotic mixture of: (i) mudstones, (ii) sandstones, and (iii) mudstone-sandstone breccia. The mudstones form the main lithology, exhibiting bedded intervals, with planar and irregular contacts, folded and deformed intervals, and chaotic intervals disrupted by sandstones (Fig. $7 \mathrm{j}$ ). The sandstones are very fine- to fine-grained, light grey, and discordant to the primary mudstone bedding (Fig. 6e, 7j). The contact between sandstone and mudstone is sharp and sometimes ptygmatically folded, or irregular, with sheared mudstone clasts at contacts and sandstone grains incorporated into the surrounding mudstone (Fig. $7 \mathrm{j}, \mathrm{k}$ ). The mudstone-sandstone breccia consists of angular to sub-angular sandstone clasts within a mudstone matrix (Fig. 6e). Clasts range in size from 15 to $<1 \mathrm{~cm}$, with contacts between the mudstone and sandstone sharp (Fig. 6e).

\section{MSB bounding zones}

The basal surfaces of the MSB unit display either thin $(<10 \mathrm{~cm})$ zones of intense deformation or sharp contacts with the underlying substrate. Updip the basal contact is characterised by a sharp contact with small-scale injection dyke structures where a sand-rich debrite (D1) in MSB overlies a high-density turbidite in MSA (well M12; Fig. 7b). Downdip to the SE in well M16 the basal shear zone is characterised by an erosively-based, $10 \mathrm{~cm}$-thick, highly sheared mud-rich debrite (D2) overlying a high-density turbidite in MSA (Fig. 4b, 7d). Sharp contacts between the underlying MSA sandstone turbidites and the MSB mud-rich debrites (D3) are observed farther downdip (well M1 and 12a-11, Fig. $7 \mathrm{~h}, \mathrm{o})$.

The top of the MSB unit is marked by an abrupt change from debrites or mudstones into banded, hybrid and slurry beds of the MSC unit (see Fig. 4b, 6). In well M12, there is a sharp contact between MSB mudstones and thicker ( 2 m) MSC slurry beds (Fig. 6f). Above this, high-density turbidites, dominate 
the upper reservoir zone. Well M16 displays a sharp contact between mudstones, and overlying banded beds that pass upwards into slurry beds (Fig. 6g, h). Well M1 displays a sharp contact between mudrich debrites (D4) and banded beds, which pass gradually upwards into high-density turbidites and hybrid-beds (Fig. 6i). The contact in well 12a-11 is not preserved in core, but the facies changes from mudstones to high-density turbidites. In the northern area of the field, well 211/7-1 comprises $8 \mathrm{~m}$ of interbedded Facies D5 and turbidite facies 1 and 2 (Fig. 6j, k, 1).

\section{MSB lateral variability}

The MSB-unit is lithologically variable across the Magnus field. In the central and southern areas of the field, the MSB unit is predominantly characterised by a sandy mudstone matrix (Facies D1-4). The isopach thickness map of MSB broadly follows the outline of MSA isopach (Fig. 7a, 15b). A change from sand- to mud rich debrite facies is observed between well 12a-9 and M12 (Fig. 9a). MSB is interpreted to pinch-out between M12 and 12-a14, located in the footwall of the Magnus Fault (Fig. 9a). In the northern area (e.g. well 7-1, Fig. 6e), the MSB is dominated by brecciated and injection fabrics (Facies D5), with an absence of Facies D1-4. In this area the MSB can also be correlated between wells 7-1 and 7a-3 ( 420 m), thinning towards 7a-6 (Fig. 9c).

\section{MSB-unit Interpretation}

The facies characteristics, together with the deformation features at its base, suggest that the MSB is a debrite. The basal deformation in some parts of the central and southern areas support interpretation of a basal shear zone (see Butler et al. 2016). Elsewhere, the basal shear is expressed as a sharp surface. The absence of internal bounding surfaces or consistent changes in character suggest that the unit was transported and deposited en masse as a dominantly cohesive debris flow in a single event, having sufficient yield strength to enable $>1 \mathrm{~m}$ diameter 'rafted' block/clasts to be transported. The larger blocks were likely incorporated from either the source area or substrate entrainment during transport based on, (i) over-turned, folded or anomalous bedding or lamination dips, (ii) irregular contacts between blocks and debritic matrix, or (iii) incorporation of debritic matrix streaks or inclusions into the blocks. The change in facies downslope from sand-rich (Facies D1) (e.g. well M12, Fig. 6a), to mud-rich debrites with higher clay contents (e.g. well M1, Fig. 6d), may represent a longitudinal flow evolution to more cohesive debris flow; as clays become increasingly disaggregated and mixed into the matrix, increasing the yield strength of the flow (Fig. 6). As the yield strength increased, larger clasts were able to be supported by the debris flow (e.g. Hampton 1975; Talling 2013). This evolution supports a transport direction towards the SE (i.e. from well M12 to M1, Fig. 7a). The trend from sand- to mud- 
rich debrite facies (D1-4) in the central and southern areas suggests a minimum runout distance of $\sim 3.7$ km between well 12a-9 and M12 (Fig. 9a).

Given the northern area of MSB unit is texturally immature (Facies DB) when compared to the debritic textures (Facies D1-4) in the central (e.g. well M16) and southern (e.g. well 12a-11) areas, it is unlikely that the northern MSB was deposited by a cohesive debris flow. Instead observations of injectite, brecciated, and soft sediment folding in Facies D5 suggest formation through hydraulic fracturing and injection processes (see Koša 2007; Satur \& Hurst 2007), in addition to minor remobilisation through slumping (Fig. 6e, 7j). This suggests Facies D5 was detached from the main central and southern debris flow, and may represent a separate failure event restricted to the northern area of the field. Alternative interpretations may include: (i) that the Facies D5 represents the injected margin of the MSB debris flow, or (ii) MSB was either very thin or not preserved in the northern area and D5 represents the boundary between the MSA and MSC.

Clay content is a controlling factor in the strength of a debris flow, with highly cohesive flows resistive to mixing with the ambient seawater, and prone to hydroplaning (Mohrig et al. 1998; Talling 2013). The character of the basal shear zone in the central and southern areas of the Magnus Field, suggests more erosion updip with lower clay content in the overlying deposit (i.e. Facies D1-2, Fig. 6b,d). The sharper basal contact downdip ( wells M1 and 12a-11 (Fig. 7h, o)) could suggest less erosion with higher clay contents in the overlying deposit (i.e. Facies D3-4, Fig. 7h). This may support a debris flow transported from the NW that was able to erode into a likely unlithified/semi-lithified substrate (primarily MSA reservoir unit), which evolved longitudinally into a highly cohesive debris flow that was prone to hydroplaning. Hydroplaning, enables debris flows to detach from the underlying substrate, and to bypass with limited or no transmission of shear stress beneath the flow (see "free-slip flows" Sobiesiak et al. 2018). Field studies of similar sized deposits (i.e. 10's m thick) show debrites can have heterogeneous basal zones including sharp, discordant, and erosive contacts (e.g. Auchter et al. 2016).

\section{PETROPHYSICS \& QEMSCAN ANALYSIS}

\section{Petrophysical properties of the MSM}

Here, we build upon the core facies analysis by correlating the lower reservoir (MSA), intra-reservoir MTD (MSB), upper reservoir (MSC, E, G, \& H), and mud-prone units (MSD \& F) establishing their distributions across the field. Units within the reservoir can be correlated across the field using the gamma-ray log and biostratigraphic data (Fig. 8, 9). 


\section{Lower reservoir (MSA)}

The lower reservoir (MSA) is characterised by predominantly low gamma-ray (GR) values ( $<75$ gAPI), indicating low volumes of shale ( $<1 \%$ average, derived from GR logs), and a neutron-density crossover consistent with high-density turbidite sandstones (Facies 1) observed in core (Fig. 8a). The compressional (p-wave) velocity (i.e. sonic log) is approximately constant (c. 80-100 $\mu \mathrm{s} / \mathrm{ft}$ ) across the interval, and the high resistivity (c. 25-270 $\Omega \mathrm{m}$ ) and oil saturation (0.79, derived from resistivity in well M16), is consistent with oil staining observed in the core (see fluorescence emission in Facies 1, Fig. 5). Breaks in these responses are rare and interpreted to represent the transitions between turbidite packages, characterised by higher gamma-ray values and limited separation between neutron-density (see Fig. 8a). These breaks correlate with the mudclast-rich intervals identified from core in Facies 1 (Fig. 5). The responses are consistent with an interpretation of predominantly amalgamated high-density turbidites in the central area of the field (Fig. 9a). Away from the central trend of the field (i.e. Fig. 9a), $\log$ values become more variable with increasing GR values (>75 gAPI), and neutron-density crossovers (e.g. M1 and M2, Fig. 7a, 9e). Calibrating these responses with core shows that variable responses in MSA can be attributed to thin-bedded low-density turbidites (Facies 2) and background mudstones (Facies 6) (see Fig. 7r). Core plugs from high-density turbidites (Facies 1) display an average porosity $=22 \%$, vertical permeability $(\mathrm{Kv})=500 \mathrm{mD}$, and horizontal $(\mathrm{Kh})$ permeability $=600 \mathrm{mD}$.

\section{Intra-reservoir seal (MSB)}

The MSB is characterised by relatively high ( $>75-250$ gAPI) gamma-ray values, related to high volumes of clays within the debrite matrix of Facies 7 (Table. 2). However, the petrophysical expression of MSB can vary depending on well location, with updip wells (e.g. M16 \& M12, Fig. 9a) characterised by an upwards increase in GR (75->150 gAPI), and downdip wells by more consistent GR response (e.g. $>125$ gAPI, M1 \& M8z, Fig. 9a). We attribute the distal expression to reflect increased mixing of clays with increasing transport distance (Fig. 6a-d). Neutron-density cross-overs reverse when compared to MSA, suggesting a predominantly clay-rich unit. Compressional velocities show an irregular signature, and resistivity values (1-2 $\Omega \mathrm{m})$ are less than in MSA, likely related to a combination of no hydrocarbon saturation, and increased saturation of conductive brine and clay minerals. However, there are resistivity peaks (c. $10 \Omega \mathrm{m}$ ) in the basal zone of MSB, which are similar to those seen in studies of more shallowly buried MTDs (e.g. Sawyer et al. 2009). 
Upper reservoir (MSC, E, G, \& H) and mud-prone (MSD \& MSF) units

The upper reservoir sand-rich units (MSC, E, G, \& H) are similar to MSA, with generally low GR values (45-80 gAPI), and neutron-density crossings consistent with sandstones. Though, the responses show more variation, related to the variety of facies (i.e. Facies 3, 4, and 5) when compared to the lower reservoir (MSA) which is dominated by high-density turbidites. The upper reservoirs can be interpreted as three turbidite dominated sequences, split by zones of increased clay content MSD and MSF. MSD/F are characterised by elevated GR (c. 100 gAPI), and reduced resistivity responses (c. $4 \Omega \mathrm{m}$ ). Core data show MSD and MSF are dominated by hybrid, banded, and slurry beds, and low-density turbidites, which are likely more conductive than high-density turbidites; explaining the reduction in resistivity. MSF can be correlated across the basin, and its top coincides with the Iathetica re-influx (Partington et al. 1993), while MSD is discontinuous across the basin. Low-density turbidites contribute little to the primary reservoir, and in cases are not oil-stained (core $\Phi=15 \%, \mathrm{Kv}=\sim 400 \mathrm{mD}, \mathrm{Kh}=\sim 575 \mathrm{mD}$ ). Core plug samples of the $\mathrm{H} 1$ intervals of hybrid-beds, show these deposits have good porosity (16-24\%) and moderate permeability $(\mathrm{Kh}=20-200 \mathrm{mD})$. Banded beds (Facies 4) near the basal section of the upper reservoir (Fig. 6g, i) show more varied, typically lower porosities $(>1-24 \%$ ) and permeabilities $(\mathrm{Kv}=\sim 0.27 \mathrm{mD} ; \mathrm{Kh}=\sim 21 \mathrm{mD})$.

\section{Fluid pressures: temporal and spatial variability}

Formation pressure in the Magnus reservoir is known to be highly variable due to sealing faults and clay-rich laterally extensive deposits (Atkinson 1985; Shepherd et al. 1990; Morris et al. 1999). Initial reservoir pressure was $6635 \mathrm{psi}$, at $3050 \mathrm{~m}$, with a gradient of $0.67 \mathrm{psi} / \mathrm{ft}$ (Shepherd 1991). Figure 10d details the production history of the field and the operational timescales of the wells discussed below.

In early production wells, repeat formation tester (RFT) pressure data display marked pressure breaks between the upper and lower reservoirs (Fig. 10a). For example, in well 211/12a-M1, the upper reservoir pressure gradient ( $0.34 \mathrm{psia} / \mathrm{ft}$ ) follows a linear trend until the top of MSB (Fig. 10a). The lower reservoir pressure measurement increase significantly above a linear trend from the upper reservoir gradient. This major pressure break (430 psia) suggests that MSB is acting as a seal, compartmentalising the upper and lower reservoirs (Fig. 10a). Similar trends are also observed in other early production wells, with ranges in pressure breaks varying from 1984 psia in well M4, to 377 psia in well M12 (Fig. 10a). Mid-production wells show much lower pressure breaks (e.g. 22 psia in well M16), in effect following the upper reservoir pressure gradient, and in many late infill wells a negative pressure differential (e.g. M31z -1976 psia) is observed between the upper and lower reservoirs (Fig. 10b).

This variability in pressure change $(\Delta \mathrm{p})$ can be related to oil field management and operational activities (i.e. production and water injection, EnQuest Internal Report) and, sealing faults laterally compartmentalising the reservoir. There was an initial increase in the $\Delta \mathrm{p}$ trend (wells M1 to M5) related 
to rapid depletion of the upper reservoir prior to the full field-wide impact of water injection (Fig. 10b), pressure differences within the reservoir is represented by variable $\Delta \mathrm{p}$ values between wells M5 to M12 (Fig. 10b). The later negative $\Delta \mathrm{p}$ (wells M30 to M41) can be related to significant water injection into the upper reservoir, and limited water injection into the depleting lower reservoir during mid to late production (EnQuest Internal Report). No correlation between $\Delta \mathrm{p}$ and MSB thickness was found, suggesting MSB variability (within the areas sampled) has little impact on the unit's ability to act as a competent seal (Fig. 10c). However, fluid pressure data in wells to the north (i.e. 7-1 and 7a-3) do not sample below MSC, therefore we cannot confirm whether or not the MSB (i.e. Facies D5, Fig. 6e, 7k) is sealing in this area. Overall, the pressure differentials suggest the MSB is a competent seal in the central and southern areas of the field.

Vertical changes in formation pressure are also observed around MSF, which acts as a local pressure barrier (Fig. 10a). For example, wells M4, M9 and M16 show negative pressure breaks (-201, -242, and -10 psia respectively) between MSG and MSE (Fig. 10a). MSD also records vertical changes in formation pressure. However, breaks are not observed consistently, which we interpret to be related to the heterogeneity of facies (i.e. Facies 2, 3, 4 and 5) within MSF and MSD. In addition, pressure breaks are not observed in initial production wells (e.g. M1, Fig. 10a) suggesting that they are related to differential pressure depletion between zones of the upper reservoir during production, rather than virgin pressures (e.g. M16, Fig. 10a). In addition to the defined reservoir zones of the Magnus Field (see Fig. 3e) formation pressure plots also show intra-zone pressure breaks, which correlate with smaller sub-zones dominated by mudstones or transitional flow deposits (Fig. 10a). These variable pressured sub-zones also validate observed preferential waterbreak along highly permeable sandstones during early production wells (see well M4, Fig. 10, EnQuest Internal Report).

\section{QEMSCAN analysis of facies}

Core porosity $(\phi)$ and permeability (vertical $\mathrm{K}_{\mathrm{v}}$ or horizontal $\mathrm{K}_{\mathrm{h}}$ ) cross-plots can help identify flow units within a reservoir: $\phi$ vs. Kh defines a moderately strong, positive trend $\left(\mathrm{R}^{2}=0.65\right)$ for the entire MSM (Fig. 8b). In a reservoir such as the MSM, with c. 60-85\% sandstone, there is obviously a distortion in the dataset with respect to core plug samples (Fig. 9). Thus data are skewed towards sandstonedominated units and transitional flow deposits (Facies 5, 4, \& 5) are underrepresented, and debrite samples (Facies 7) are absent.

We therefore used QEMSCAN to quantify the difference in mineralogy, grain size, and porosity of facies sampled from well 211/12a-M16 (Fig. 2). In addition, QEMSCAN also allows analysis of depositional textures, particularly useful for debrites. Fourteen samples were collected (QM1 to QM14, see Fig. 4a for depths). Sample QM10 recorded scanning errors due to sample damage, thus its results are considered unreliable (see Fig. 14a). The grain-size distribution in QM6 is also artificially skewed 
towards the coarser end of the grainsize spectrum as some grain-grain contacts could not be resolved by the image-processing software (Fig. 13). The field of view in the mineral maps (QEMSCAN images) is approximately $2 \times 2 \mathrm{~cm}$ (Fig. $11 \& 12$ ), the data is therefore $2 \mathrm{D}$, and hence permeability cannot be quantified. An index of core images showing exact sample depths of QM1-14 can be found in the Supplementary Material 2.

\section{Mineralogy}

Using a quartz-feldspar-lithics ternary plot, MSM samples fall within the sub-arkose, arkose, lithic arkose, and feldspathic litharenite categories (Fig. 14b). Lithics were calculated by summing all other mineral percentages excluding clays which are predominantly authogenic (e.g. kaolinite and illite) (see Fallick et al. 1993). Quartz is the dominant detrital mineral (c. 20-60\%), apart from QM9, which sampled a mud-rich debrite with c. 30\% illite. The high-density turbidite samples (QM6 \& 14) and the hybrid-bed basal sandstone (QM12) (Facies 1, 2, \& 5), plot within the arkose to sub-arkose category. All have low $(<10 \%)$ amounts of lithics. Debrites (QM5, 7, 9), and the banded bed (QM8) samples, all display a high proportion of lithics spanning the lithic arkose to feldspathic arenite categories. Diagenetic clay overgrowths are present in all turbidite samples, but are generally minor (e.g. 1.85\% illite, QM1), increasing in proportion when grain size decreases (e.g. c. 6\% illite, QM4), with samples displaying pore-bridging illite fabrics (see QM2, Fig. 11). In the basal hybrid bed sandstone, clay content increases upward accompanying a transition from H1-H3 (QM12, Fig.12, Fig.5) (see Haughton et al. 2009). Heavy mineral content (zircon, iron oxides, and apatite), show no distinct change or trend between the lower reservoir (QM1-4), MSB (QM5-9), and the upper reservoir (QM11-14).

\section{Grain-size distributions \& reservoir quality}

Grain size distributions were extracted from QEMSCAN images. Our samples span a range of grainsizes, from 1-20 $\mu \mathrm{m}$ (clay-silt) to $>1000$ um (very coarse sand). Distributions can appear skewed towards coarser or finer populations, or approximate a normal (gaussian) distribution (Fig. 13). As expected, high-density turbidites (Facies 1) show a skew towards coarser $(>125 \mu \mathrm{m})$ grain size populations (QM1-4, Fig. 13). There is, however, some variability depending on precisely where in the bed the sample comes from (e.g. QM11 vs. QM1, Fig. 13). QM11, which is taken from the base of a bed, displays a significant coarse-grained skew, with most of the grains $>250 \mu \mathrm{m}$, whereas samples from middle and upper parts of turbidite beds have normal distributions (e.g. QM13, Fig. 13). A lowdensity turbidite sampled by QM14 shows a fine-grained skew, with silt and very fine sand dominating the sample. The hybrid-bed (H1) shows a finer skew than high-density turbidites, with no sand grade over medium (QM12, Fig. 13). QM12 also shows a distinct normal grading, increasing in fines towards 
the top of the sample (Fig. 12). The banded bed sample shows a similar trend to QM14, with distinct grain size breaks visible in the mineral maps (QM8, Fig. 12). The MSB debritic matrix demonstrates a broadly normal distribution of grain sizes in samples QM5 and QM7, with the grain size ranging from coarse sand to clay-silt grade material. QM9 samples the mud-rich debrite part of MSB, showing an increase in clay-silt grade material, and imbricated/shear fabrics (Fig. 12).

Clay content is defined by a combination of the percentage of glauconite, illite, chlorite, kaolinite, smectite, and other secondary clays (see Supplementary Material 2). Total clay versus total porosity demonstrates a strong, positive relationship $\left(\mathrm{R}^{2}=0.84\right)$. High porosity $(17-26.5 \%)$ and low clay content $(<10 \%)$ characterise the high-density turbidite samples, consistent with the primary reservoir facies (Fig. 14a). In the thin-bedded turbidite sample (QM14), detrital and diagenetic clays exceed 40\%, reducing porosity to $<5 \%$ and rendering them ineffective reservoirs. The hybrid-bed sample (QM12) clay content is elevated when compared to high-density turbidites, with a porosity of c. $15 \%$, but likely still contribute to net pay (Fig. 14a). Core porosity and permeability measurements from hybrid beds demonstrate they may act as reservoirs in the cases of the lower most sandstone divisions (H1) (c. $\Phi=$ $20 \%, \mathrm{Kh}=200 \mathrm{mD}$ ), with debritic divisions (H3) acting as baffles $(c . \Phi=9 \%, \mathrm{Kh}=10 \mathrm{mD})$. Debrites and banded beds show high clay fractions $(>37 \%)$, and low total porosities $(<10 \%)$, and likely insignificant effective porosity, with connectivity between pore throats limited (Fig. 13, 14a). It must be noted that the sample dataset is small and spatially restricted to well M16. Therefore, these data show the potential of using QEMSCAN methods to characterise reservoir quality.

\section{SEISMIC ANALYSIS OF THE MSM RESERVOIR}

Seismic facies analysis of the MSM reservoir supports a slope to basinfloor environment, which is consistent with previous Magnus reservoir studies (e.g. Shepherd et al. 1990; Ravnås \& Steel 1997). This is illustrated in the context of two seismic units: (i) the lower reservoir (Top Heather to Base MSB interval), and (ii) the upper reservoir (Base MSB to the BCU interval) (Fig. 2).

\section{Lower reservoir}

The lower reservoir comprises the MSA plus Lower Kimmeridge Clay Formation (Figs. 2 and 3) and is defined by a centrally located depocentre (up to $285 \mathrm{~m}$ thick), which is partially confined by WNWESE striking faults, and the N-S trending Brent Fault High (Fig. 15). The updip (i.e. to the NW) edge 
of this interval is characterised by a narrow isopach thick, while downdip it thickens into a broader depocentre (Fig. 15b). The downdip (i.e. to the SE) thickening of the MSA in the central area coincides with an increase in the proportion of high density turbidites (c. $20 \mathrm{~m}$ to $>150 \mathrm{~m}$, Fig. 9a), while thinner sequences characterise southern and northern areas (c. $<25 \mathrm{~m}$, Fig. 9b, c). The WNW-ESE striking faults do not offset the MSA reservoir, but instead tip-out in the Lower Kimmeridge Clay Formation, with stratal thickening into the faults. Hence, these faults were not active, but formed an irregular topography that shaped the distribution of the MSA (Fig. 15a). The seismic character of the MSA displays a clear updip to downdip transition. The updip area comprises a confined (650 $\mathrm{m}$ wide), continuous, high-amplitude and low acoustic impedance reflector (Fig. 15a, X-X'). This reflector exhibits a mounded geometry with positive relief, reflecting differential compaction around sand-rich fairways (i.e. wells M12 and M16, Fig 9a). Further downdip, the MSA reflector initially widens (c. 1.5 km) (Fig. 15a, Y-Y') and then transitions into two reflectors with high-amplitude and high continuity in the central area and lower amplitude and thinning to the north and south (Fig. 15a, Z-Z'). Amplitude extractions taken from the top MSA show the distribution of the reservoir, imaging a centrally confined channel form in an inferred upper to mid slope position, expanding downdip into a lobate geometry (c. $10.25 \mathrm{~km}^{2}$ ) (Fig. 15b, $-30 \mathrm{~m}$ offset). The system then backsteps up the slope, until there is no reservoir amplitude response, marking the boundary with the mud-prone MSB (Fig. 15b, -10 m offset). The gross geometry of the MSA is consistent with the petrophysical and core analysis, which shows a predominance of high density turbidites in the central MSA fairway area, and more mud-rich thinbedded turbidites (Facies 2), injectites, and background mudstones (Facies 6) further downdip and along strike (northern and southern areas).

\section{Upper reservoir}

The upper reservoir comprises the upper MSM (Base MSB to Upper Kimmeridge Clay Formation/BCU interval; Figs. 2 and 3), which is split into two depocentres, trending axially to the Penguin half-graben: (i) a southern depocentre within the hanging-wall of the Brent Fault, and (ii) a north-eastern depocentre (Fig. 16b). The Brent Fault tips out within the MSM, and was active during the deposition of the upper reservoir based on thickening into its hanging-wall (Fig. 16a, Y-Y1). The reflectors are high-amplitude but contain both high and low acoustic impedance responses that are more discontinuous than the lower reservoir (Fig. 16a, X-X'). Amplitude extractions from near top MSM, show high amplitudes are truncated by the BCU (Fig. 16b, $-20 \mathrm{~m}$ ). Amplitudes trend SW, increasing from isolated linear forms to more connected responses, suggesting a possible change in the sediment supply direction when compared to MSA (Fig. 16b, $-50 \mathrm{~m}$ ). The upper reservoir is more heterogeneous than the lower reservoir, preventing calibration of individual facies to the seismic response. However, backstepping of the system to the NE is inferred from an absence of high amplitudes in the south near the top of the 
reservoir (Fig. 16b, $-50 \mathrm{~m}$ to $-20 \mathrm{~m}$ ). The upper MSM is overlain by a continuous high-amplitude response in the south-east of the field (Fig. 16b), which is interpreted as the Upper Kimmeridge Clay Formation (Fig. 9f).

The upper reservoir also contains several footwall-collapse structures, which can be interpreted as an MTC (i.e. seismic-scale MTDs), with hummocky upper surfaces and high amplitude basal shear zones (Fig. 17) (e.g. Bull et al. 2009; Steventon et al. 2019). The intact rotated blocks and discrete faulting suggests the MTC supports emplacement by slump processes (e.g. Mulder \& Cochonat 1996). In some slumped areas updip extensional faults, which offset the BCU and detach into the MSB mudstone-rich unit, create a complex reservoir architecture in areas affected by footwall degradation (Fig. 3d) (e.g. Underhill et al. 1997; McLeod \& Underhill 1999).

\section{MSM Depositional Environment}

In the lower reservoir, the combination of an updip channel form, and downdip lobate geometries, with the dominance of high-density turbidites (Facies 1) supports a depositional model with (1) sediment supply from the NW, (2) a central updip slope portion characterised by a confined submarine channel, and (3) a downdip toe-of-slope area represented by a turbidite lobe complex (Prélat et al. 2009) (Fig. 15). The updip channel is dominated by coarse grained lag deposits (well M12, Facies 1, Fig. 5), representative of proximal areas near sediment input points and channels where bypass of turbidity currents is common (e.g. Stevenson et al. 2015). The downdip central area is also dominated by high density turbidite facies and is interpreted to represent the axis of a lobe complex. The mudclast-rich zones may represent boundaries between lobes (Fig. 5). Away from the central axial area, thin-bedded sandstones and background/turbidite mudstones are interpreted as off-axis to lobe fringe environments (Mutti 1977; Walker 1985; Kendrick 1998; Passey et al. 2006).

The MSB debrite forms a seal between the two reservoirs and is composed of predominantly mud-rich debrite, coeval with the Autissiodorensis maximum flooding surface (Fig. 7, 9). Unit MSB thickens SE, following the thickness trend of the lower reservoir, and becomes more mud-rich in this direction, we interpret the source area to be from the NW (Fig. 7a). This is consistent with the palaeo-dip of the slope to the SE (Fig. 3c, d). The Magnus dataset only covers part of the MSB, which extends across the Penguin half-graben (Morris et al. 1999). From the Magnus to Penguin-A Field, the MSB unit shows a thickening trend up to $33 \mathrm{~m}$, terminating against the Penguin Horst (Al-Abry 2002). Al-Abry (2002) also notes the presence of debritic and slumped facies confined to the collapsed terrace areas of the Penguin Horst, relating their presence to slope instability, while identifying other areas to be dominated by background mudstones (Fig. 18b). This suggest that the MSB debritic unit (i.e. Facies D1-4) in the 
Magnus area forms one of at least two debrites, initiated and transported towards the basin centre during a period of instability. We infer that the two debrite units are isolated to the slope and terrace areas of the Magnus and Penguin-A Fields respectively (Fig. 18b). Facies D5 in the northern area of the Magnus Field is interpreted to form as a separate deposit (Fig. 18b). Overall, we interpret the MSB to represent basin instability after a period of sand starvation possibly related to relative sea-level rise (e.g. Piper et al. 1997; Strachan 2002; Grecula et al. 2008).

The upper reservoir comprises at least two lobe complexes, separated by the mud-dominated MSD and MSF units (Figs. 9a and 16). The NE-SW trending linear amplitudes are interpreted as distributary channels, suggesting sediment supply from the NE (Fig 16b). However, an alternative interpretation may be that the linear amplitudes represent linked fault bound depocentres which have focused sediment axially along the field. As the Brent Fault was an active palaeo-high during deposition, it is likely the southern depocentre input point was near the original lower reservoir channel, while the northern depocenetre was located NE of the Magnus Field (Fig. 16b). Facies within the upper reservoir are dominated by high-density turbidites, with thin-bedded sandstones, banded, hybrid and slurry deposits common in both the MSD and MSF units. In other studies, banded beds have been observed at the transition between lobe axis and off-axis settings (e.g. Spychala et al. 2017b), or in proximal lobe settings (e.g. Stevenson et al. 2020). In the upper reservoir banded sandstone beds are concentrated above the mud-rich MSB unit (see Fig. 6f-i) suggesting that banded sandstone beds in MSC represent initially turbulent sediment-gravity flows interacting with the mud-rich slope substrate of MSB (e.g. Davis et al. 2009; Stevenson et al. 2020). Hybrid and slurry beds are typically diagnostic of frontal lobe fringe environments (e.g. Barker et al. 2008; Spychala et al. 2017b), and may also mark fan initiation cycles (e.g. Hodgson 2009). In the Magnus Field, transitional flow deposits and low-density turbidites are dominant in the lower MSC, MSD and MSF of central and southern wells (e.g. Fig. 6h, well M16), with fewer in the northern area of the field (e.g. see Facies proportions, Fig. 9). This supports the overall upper reservoir system being sourced from the NE, with well 7-1 in a proximal and axial fan location, supported by the dominance of high-density turbidites and limited number of transitional flow deposits (Fig. 6j-1, Fig. 9). This is supported by the distribution of high amplitudes in the upper reservoir, which backstep to the NE (Fig. 16b). In the central and southern areas, we interpret the system to be in a predominantly axial fan location, evidenced by the dominance of high-density turbidites. However, distinct mud-prone units (MSD and MSF) represent periods of lateral shift and/or system backstepping to the north, moving the central and southern areas into off-axis or distal positions, and therefore, promoting the deposition lobe fringe deposits. This interpretation is consistent with the Magnus Field being located on the basin margin of the Penguin half-graben. Similar observations were made farther north in the basin where high-density turbidite axial lobe deposition was correlated with fan fringes dominated by transitional flow deposits (Haughton et al. 2003). 


\section{DISCUSSION}

\section{Evolution of the submarine slope depositional system in the Magnus reservoir and wider Penguin half-graben}

The MSM records a significant sediment pulse during relatively high subsidence rates in the Penguin half-graben (Al-Abry 2002), and is coeval with the uplift of the Nordfjord High (see Fig. 2 inset map) to the north west and Shetland Platform to the west of the study area (Ziegler 1990; Ravnås \& Steel 1997). The MSM has been observed to onlap the Penguin Horst, indicating it was an active paleo-high during deposition (Dominguez 2007). However, it is likely the Magnus and End of the World faults recorded only minor activity, or were dormant during much of MSM deposition (Ravnås \& Steel 1997) (Fig. 2, inset maps). Sedimentation during the MSM can be separated into four stages: (i) confined sediment input derived from the north-west, (ii) a period of relative sea-level rise and basin instability, (iii) a switching of sediment input to a northern province, and (iv) a further period of instability.

Stage 1: The lower reservoir (MSA) is characterised as a centrally restricted, fault-controlled channellobe complex, sourced from a single north-westerly input point (Fig. Fig. 15b \& 9a). Probable hinterlands source areas include the Magnus Basin (North Shetland Trough), which had not fully subsided at this time, and the Nordfjord High/Margareta Spur. Ravnås \& Steel (1997) propose a filland-spill model for the MSM deposition, interpreting that the Magnus Basin had limited accommodation, promoting sediment transport farther basinwards into the Penguin half-graben (Fig. 18a). An alternative interpretation is a sediment source from the Shetland Platform to the west, similar to other Upper Jurassic deep-water systems in the Moray Firth and Viking Graben (Shepherd et al. 1990).

Stage 2: MTDs are typically associated with shelf-edge and/or slope instability (e.g. Nemec et al. 1988; Nemec 1990; Mayall et al. 1992; Galloway 1998). The mud-rich character of the MSB debrite support its association with a period of reduced clastic input and precedes reorganisation of sediment supply from the north-west (lower reservoir) to the north (upper reservoir) (Fig. 18). Increased subsidence is likely during this time, due to fault population linkage correlating with the formation of the maximum flooding surface (Autissiodorensis), and an increase in hemipelagic radiolarian diversity (Morris et al. 1999; Al-Abry 2002) (Fig. 9). Therefore, the preconditions to slope failure may have been relative sealevel rise and hemipelagic sedimentation, and slope steepening due to tectonism, with failure across a weak mud-rich layer (e.g. Bull et al. 2009; Spychala et al. 2017a). Similar debrite facies with starrynight textures have also been observed to compartmentalise other turbidite reservoirs in the North Sea (e.g. Britannia Field, Barker et al. 2008; Eggenhuisen et al. 2010), and in outcrop-based studies (e.g. Pickering \& Corregidor 2005; Jackson \& Johnson 2009; Auchter et al. 2016). 
Stage 3: The input direction for the upper reservoir (MSC-H) is interpreted to change to the north-east, evidenced by the SW-trending seismic amplitudes and axial trending depocentres (Fig. 16b). This suggests a shift in sediment supply from north-west to north, with potential sources including the Makrell Horst/northern Penguin Ridge and the Magnet Ridge (Ravnås \& Steel 1997; Gabrielsen et al. 1999; Al-Abry 2002). However, heavy mineral percentages from QEMSCAN show no change between upper and lower reservoirs, which may suggest either: (i) provenance change in sediment routeing pattern but not source area, or (ii) a change in catchment area with eroded sediments being mineralogically consistent between the two areas.

Stage 4: During the latest Jurassic to earliest Cretaceous, the basin transitioned from sand-rich MSM deposition into the mud-dominated Upper Kimmeridge Clay Formation. This transition is associated with the Hudlestoni maximum flooding surface (base J66), which can be correlated across the basin (Morris et al. 1999). This relative sea-level rise may be associated to the linkage of the Magnus and End of the World basin-bounding faults, related to the opening of the Magnus Basin (North Shetland Trough) and the Møre Basin, to the west of the study area (Fig. 17c). The observed slumping in the upper MSM was likely caused by increased activity on basin-bounding faults and associated uplift and tilting of their footwalls (Fig. 17).

\section{Identifying sealing sub-seismic MTDs}

Understanding of the sealing potential of MTDs is important for several applications including: (i) the distribution of reservoir-seal pairs, and stratigraphic traps during exploration, particularly on unstable basin slopes (e.g. Sabah, NW Borneo, Grecula et al. 2008), (ii) understanding reservoir compartmentalisation during hydrocarbon production, and (iii) subsurface pore pressure prediction and the correct placement of well engineering (e.g. casing shoes) during drilling operations. Numerous studies have shown the sealing capacity of seismic-scale MTDs (e.g. Flemings et al. 2008; Algar et al. 2011; Dugan 2012; Day-Stirrat et al. 2013; Cardona et al. 2016; Sun et al. 2017; Wu et al. 2019). These studies highlight the importance of densification and shearing, causing enhanced alignment of clay minerals along basal shear zones, leading to a reduction in porosity and permeability. Through the analysis of core, petrophysical, and particularly pressure data, we have demonstrated the ability of a sub-seismic MTD (MSB) to act as a competent sealing unit.

Initial identification of abrupt pressure barriers between reservoirs or internally within a reservoir zone, is a useful method for identifying potential sealing-MTDs (Fig. 10a). Petrophysical logs should allow a distinction between mud-rich sub-seismic MTDs and slope mudstones. However, with increasing burial and compaction, along with hydrocarbon charge, log responses identified from studies of shallower sections (e.g. $<1 \mathrm{~km}$ ) can become unreliable in predicting deeply buried sealing-MTD (e.g. Sawyer et al. 2009; Day-Stirrat et al. 2013). It should also be noted that wireline logging tools have a 
vertical resolution of $\sim 0.15 \mathrm{~m}$, and therefore, will only characterise trends throughout an MTD and not core scale heterogeneities (Table 2). Gamma-ray values are generally high (> 75 gAPI), related to high volumes of clay in the MTD matrix, but can be variable depending on the lithology of entrained clasts and large blocks. Density motifs in shallow studies are characterised by high values when compared to surrounding sediments, and peaks in the basal zone are attributed to shearing and over consolidation (Dugan 2012; Wu et al. 2019). In the Magnus Field, the MSB unit demonstrates higher densities than bounding sedimentary successions, similar to shallow studies $(<1 \mathrm{~km})$. However, caution should be taken when using this approach below the sand/shale density crossover ( $\sim 600 \mathrm{mbsf}$, Cook \& Sawyer 2015), and in deeper formations, as sandstone can become much denser than shale, particularly during the onset of cementation (e.g. Avseth 2000). Neutron-density plots should display a cross-over with neutron to the left and density the right, indicating a shale response (Fig. 8a). In shallow studies, resistivity in MTDs is generally higher than background sediments and is particularly elevated in the basal zone (e.g. Day-Stirrat et al. 2013). This increase is attributed to densification and porosity loss when compared to background mudstones (Flemings et al. 2008; Dugan 2012). In this study, we observed a similar downward increase in resistivity within the MSB unit, with a peak in the basal zone (Fig. 8a). However, below the MSB resistivity increases further in the oil-filled MSA reservoir, and therefore, resistivity should not be discriminating factor when identifying MTD-based hydrocarbon seals (Fig. 8a). MTD porosity should be low ( $<10 \%$ ) (Fig. 4, PHIT), with possible isolated high-porosity zones generated by entrained clasts (e.g. sample QM6, Fig. 14a). Volumes of clay are likely to be very high (e.g. 37-57\% in MSB, Fig. 14a).

Recognition of sub-seismic sealing MTDs should be undertaken through the integration of multiple datasets, particularly pressure measurements which provide a valuable dynamic validation of hydraulic sealing. For example in the Måløy Slope, offshore Norway, sub-seismic debrites and slumped units can be identified by integration of well logs through electro-facies analysis (Prélat et al. 2015). The Buzzard Field, in the Central North Sea, shows how intra-reservoir mud-prone slump units were initially predicted to be sealing, however, during production bounding reservoir units were found to be in pressure communication (Ray et al. 2010). Hence, individual motifs from a single log or core sample alone cannot reliably indicate a sealing-MTD. Multiple log motifs and formation pressures should be observed in unison. In addition, MTDs are likely to show higher spatial and stratigraphic variability, when compared to background sediments.

\section{Lateral variability of the MSB and impact on later deposition}

Sources of mud for the MSB unit and younger transitional flows

Mud-rich substrates and/or source areas are important for the development of laminar and transitional flows, in both the initiation stages of shear failure as in the case of MTDs, or during flow 
transformation(s) of hybrid, banded, and slurry beds (e.g. Haughton et al. 2003; Davis et al. 2009). Flume tank experiments have shown the development of cohesive debris flows needs $>10-15 \%$ of cohesive fines $(<20-30 \mu \mathrm{m})$ (Talling 2013). The fines content of transitional flow deposits varies spatially, and can be explained through several mechanisms including: (i) deposition of coarser fractions during the initial flow, (ii) variation in substrate and entrainment of mud-rich fractions causing longitudinal flow transformation, (iii) failure of a heterogeneous source, and (iv) partial transformation of debris flows (Haughton et al. 2003; Barker et al. 2008). However, for both laminar and transitional flows, sources of cohesive muds are essential. The MSB and MSF units validates the importance of coring clay-rich units, and not initially assuming they represent background mudstone sedimentation. MSB also demonstrates that correlation of maximum flooding surfaces (e.g. Autissiodorensis of MSB) and hemipelagic radiolaria diversity do not necessarily equate to in situ hemipelagic mudstones. Morris et al. (1999) suggest the interpretation of microfossils within the MSB is not decisively hemipelagic, but rather a mix of hemipelagic and low-density mud-rich turbidites. This suggests that mudstones could have been sourced partially from hemipelagic sedimentation, and partially from mud-rich turbidites, during a period of relative sea-level rise (Fig. 15b, 18a). Volumes of mudstone deposited by muddy turbulent flows can be significant (10s m), even near sediment entry points (see Boulesteix et al. 2019). In the case of the MSB unit, it is probable that hemipelagic sediments and muddy turbidites were remobilised and entrained into the interpreted cohesive debris flow (MSB). This suggests the Penguin half-graben experienced variability in the thickness and source of mudstone sedimentation, both during and after the deposition of the sand-grade MSA. Thus, the extent of the MSA may influence the lateral and downslope variability of the MSB, described below.

\section{MTD lateral variability and sealing}

Sedimentation rates and a source of sediment for mass-transport is an important consideration, with many tectonically active margins experiencing low sedimentation rates recording limited masstransport processes (e.g. Tappin et al. 2007). Laterally the MSB can be split into: (i) central and southern areas characterised by mud and clast rich debrites (Facies D1-4, Table 2), and (ii) a northern area characterised by injectites and slumping fabrics (Facies DB, Table 2, Fig. 17b). This observed variability correlates with the presence and composition of the underlying MSA reservoir (Fig. 7a). In the central and southern areas, deposition of sand- and mud-grade material from the MSA channel-lobe complex, would have enabled the debris flow to preferentially entrain sandy-substrate. This combined with subsequent relative sea-level rise (Partington et al. 1993), and fault activity (Al-Abry 2002), would provide preconditioning factors for shear failure and the development of a cohesive debris flow. Preferential entrainment of the axial part of channel-lobe systems during mass-transport has also been observed in other systems (e.g. Magdalena Fan, offshore Columbia, Ortiz-Karpf et al. 2017). 
The northern area experienced lower sedimentation rates during the MSA period, and was topographically elevated compared to the central and southern areas, hence the absence of cohesive debris flow deposits. As the northern MSA interval was not charged with oil, the MSB has not been dynamically tested as a seal (e.g. well 7-1, 7a-3, Fig 7a). However, inclusion of sand injectite fabrics in the northern MSB, may indicate the presence of larger injectites which can act as efficient fluid flow conduits between disconnected reservoir units, casting uncertainty on seal integrity in the area (e.g. Hurst \& Cartwright 2007; Cobain et al. 2017; Dodd et al. 2019).

Understanding the lateral variability of clay-rich zones should be considered an important component of hydrocarbon seal evaluation. The MSB highlights the importance of this by demonstrating that in slope settings, laterally continuous clay-rich zones that are associated with maximum flooding surfaces do not always correlate with hemipelagic/pelagic sedimentation. MSB demonstrates that clay-rich subseismic MTDs can act as competent seals, but lateral heterogeneities can pose a risk to seal integrity. It should be noted that there is likely uncertainty in MSB short-scale variability (i.e. $<10$ 's $\mathrm{m}$ ), which has been identified in field examples of other debrites rich intervals (e.g. Fonnesu et al. 2015; Auchter et al. 2016).

\section{Flow-deposit interactions above the MSB}

Above the MSB unit, particularly in the central region of the Magnus Field, the stacking of transitional flow deposits and hybrid beds follows a common pattern (Fig. 6). The lower part of MSC is characterised by a transition between mud-rich debrites, and slurry flows and/or banded beds, which are common throughout many of the cores (e.g. Fig. 6, M1, M12, M16). This is consistent with flows entraining a mud-rich substrate after the emplacement of the MSB debrite, and the rerouting of the sediment transport system to a NE input leading to flow transformation. However, hybrid beds are most common after the initial transition, and are distributed throughout the upper reservoir interval. This is common when slopes are in constant out-of-equilibrium states, as was probably the case in the Penguin half-graben (Haughton et al. 2009).

Therefore, we suggest an idealised stacking pattern after the deposition of a mud-rich MTD, whereby flows are prone to transformation, leading to the preferential deposition of transitional flow deposits (Fig 19f). This idealised stacking pattern implies that the paleo-seabed was mud-rich and the emplacement of the MSB debrite likely modified pre-existing sediment dispersal patters, forcing flows through poorly established routing systems. These two factors may explain how turbulent flows were preferentially susceptible to becoming charged with mud and transformed into transitional flow types in the lower part of MSC. The preferential development of transitional flow deposits directly above mud-rich MTDs is important for the reservoir potential of the lower MSC, which has been negatively 
impacted (see Fig. 14a, 19f). The recognition of this idealised stacking pattern may also be important for predicting the reservoir potential of other deep-water turbidite reservoirs.

\section{Reservoir architecture and transitional flow deposit heterogeneity}

The core porosity and permeability data, and QEMSCAN results support identification of principal reservoir facies (Facies 1, 2, and 4 ) and barriers/baffles (Facies 3, 4, 5 \& 6) within the Magnus Field. Figure 14a demonstrates the influence of sediment gravity flow type on reservoir quality and shows a similar overall trend to other studies comparing sediment gravity flow mechanism and reservoir quality (Porten et al. 2016; Southern et al. 2017). Below we consider the reservoir architecture within the Magnus Field, and bed-scale heterogeneities of barriers and baffles, including their potential effects on $\mathrm{Kv} / \mathrm{Kh}$, reservoir modelling, and production from a sand-rich submarine channel-lobe system.

\section{Reservoir architecture}

Figure 19 summarises the reservoir architectures observed within the Magnus Field. The central area captures the full extent of the reservoir with a thick lower lobe complex (MSA), widespread debrite deposition (MSB) and a full upper reservoir sequence (MSC-H) (Fig. 19a). In the southern area the lower reservoir is thin or absent and the upper reservoir is divided by the Brent Fault High. In the northern area, the lower reservoir is also thin or absent, and the upper reservoir's stratigraphic architecture is complicated by gravitational faulting and a distinctive MSB which we interpret to be confined to a small area of the slope (Fig. 18, 19). The central area of the lower reservoir is estimated to be composed of $\sim 80-90 \%$ high-density turbidites, and therefore is highly homogeneous with no significant baffles impacting production $(\mathrm{Kv} / \mathrm{Kh} \approx 0.8)$ (Fig. 19e). The pressure data also shows that the MSB within the central and southern areas acts as a competent sealing unit compartmentalising the upper and lower reservoir (Fig 19e). Sealing faults are known to have split the field into numerous sectors with deep-seated extensional and slump faults (Fig. 17) impacting reservoir production (Shepherd et al. 1990).

In addition to these major features which were identified early in field development and production (e.g. De'Ath et al. 1981; Shepherd 1991; Morris et al. 1999) we also identify the role transitional flow deposits play in controlling vertical permeability and differential pressure depletion within the upper reservoir (Fig. 10). Shepherd et al. (1990) showed the significance of mudstones within the upper reservoir, which were observed to act a laterally extensive baffles to fluid flow, compartmentalising the field into four sand-rich reservoir units. Here, we can demonstrate that transitional flow deposits are 
also acting as intermittent pressure discontinuities, namely in the MSD and MSF, but also within subzones of the Magnus field (Fig. 10a). The Magnus Field demonstrates how transitional flow deposits can impact vertical permeability, showing that they can isolate reservoir sandstones and negatively impact the sweep efficiency (i.e. the volume of reservoir contacted "swept" by injected fluids, Lake 1989) during waterflooding and enhanced oil recovery (Fig. 10a).

\section{Bed-scale heterogeneities and outcrop analogues}

Capturing bed-scale heterogeneities and the geometry of baffles and barriers is important for understanding reservoir properties, distribution, and sweep efficiency. Begg \& King (1985) demonstrate the importance of characterising baffle dimensions, showing exponential relationships between increasing baffle dimension (i.e. thickness, width, length) and decreasing effective $\mathrm{K}_{\mathrm{v}}$ (Fig. 19d). The 3D nature of baffles and barriers is particularly important, as 2D reservoir simulations of impermeable heterogeneities often significantly overestimate their effect on reservoir production (see Jackson \& Muggeridge 2000). A limitation of reservoir modelling is that many impermeable heterogeneities captured in core may be lost through the upscaling process during reservoir simulation, whereby a reservoir model ( $\sim 50-100 \mathrm{~m}$ grid scale) aims to realistically capture 3D bed-scale heterogeneities (Fig 19d). However, high resolution reservoir modelling and new technologies such as surface-based grids (e.g. Jackson et al. 2014; Jacquemyn et al. 2019) and adaptive reservoir model grids (e.g. Melnikova et al. 2016) are beginning to allow reservoir models to realistically capture heterogeneities identified during wireline and core logging. To achieve this, outcrop analogues can be used to aid in the understanding of baffle dimensions.

In the Magnus reservoir we have identified several facies which act as baffles to fluid flow (Facies 2, $3,4,5$ ) or if amalgamated act as barriers (i.e. MSF) (Fig. 19e, Table. 2). However, we are not able to correlate individual beds across the field. Outcrop examples of transitional flow deposits allow us to take subsurface observations and compare these with possible analogues, where correlation along well exposed outcrop allows confirmation of dimensions. The Ross Sandstone Formation, in county Clare, Ireland, may provide a suitable outcrop analogue. The formation is composed of a sand-rich deep-water channel-lobe system, with a relatively high-proportion of hybrid-event beds and MTDs (e.g. Pierce et al. 2018). Although the Clair Basin was in a tectonically inactive (post-rift), unlike the Penguin halfgraben (Pyles 2007). Studies focusing on the Ross Sandstone's lobe fringe environment where lowdensity turbidites and hybrid beds dominate have shown they can be correlated for $\sim 1 \mathrm{~km}$ (Pierce et al. 2018). Pyles \& Jennette (2009) identified these fringe areas to have lower net to gross and a higher proportion of MTDs. Other outcrop studies of transitional flow deposits include: the Gottero Turbidite Sandstone in north-west Italy, here hybrid beds can be correlated for $\sim 4 \mathrm{~km}$, with both laterally continuous and discontinuous morphologies (see Fonnesu et al. 2018); and the Skoorsteenberg 
Formation, Karoo Basin, South Africa, where hybrid beds are preferentially concentrated in lobe fringe environments, where individual beds can be tracked for $\sim 0.5-1 \mathrm{~km}$, becoming amalgamated updip and along-strike (Hodgson 2009).

These outcrop examples demonstrate how transitional flow deposits may form 100's m scale baffles to fluid flow. Studies of other Upper Jurassic North Sea turbidites reservoirs (e.g. Brae-Miller-Kingfisher fan system) have interpret the debritic intervals of transitional flows to be widespread across the system, evidenced by large exotic (i.e. non slope derived) clasts (Haughton et al. 2009). Therefore, assuming the model of increasing thickness of $\mathrm{H} 3$ (i.e. debritic divisions) towards the fan fringe (see Haughton et al. 2003), it is likely that hybrid beds in the upper reservoir of the Magnus Field are laterally continuous from mid-fan to fan fringe environments. This model is consistent with our observations of pressures, where transitional flow deposits reduce the vertical permeability, connectivity of turbidite facies, and sweep efficiency during production (Fig. 10, 19e). Amy et al. (2009) undertook a 2D reservoir flow simulation of the Marnoso Arenacea Formation in northern Italy, composed of sheet-like basinfloor turbidite sandstone with related transitional flow deposits. They similarly found beds containing significant debritic material (porosity $<15 \%$, permeability $<100 \mathrm{mD}$ ) reduced production efficiency and led to quicker water breakthrough. Our results highlight the importance of characterising not just background mudstone but also other non-reservoir rocks. This is particularly true for transitional flow deposits which are in most cases genetically related to the distribution of turbidite reservoirs (e.g. Davis et al. 2009; Hodgson 2009; Spychala et al. 2017b). These deposits should be properly characterised during reservoir modelling studies of turbidite channel-lobe systems, in order to adequately capture the heterogeneities in rock properties and simulate fluid flow within a reservoir.

\section{CONCLUSIONS}

(i) The evolution of the Magnus Sandstone Member's depositional system in the Penguin halfgraben can be divided into 4 main phases: Phase 1 deposition of a centrally fault controlled channel-lobe complex dominated by high-density turbidite facies, with a likely provenance from the north-west, Phase 2 a period of flooding slope instability and deposition of a mud-rich debrite by a cohesive debris flow, Phase 3 a shift of sediment supply from the north-west to the north/north-east, and deposition of lobe complexes along the axial trend of the half-graben, and Phase 4 a relative sea level rise, basin tilting, and slumping within the Magnus footwall. Postrift thermal subsidence continued during the Cretaceous and Tertiary sequences. 
(ii) Sub-seismic MTDs can act as competent sealing units at depth. Identification of such deposits is best undertaken through the integration of fluid pressure, petrophysical, and core data. Distinguishing features include abrupt pressure barriers between permeable flow units, diagnostic motifs of logs (bulk density and resistivity) through comparison of MTDs with background mudstones, variability in response across the deposit, high ( $>35 \%)$ volumes of clay, and sedimentary structures associated with shear failure and mass-transport processes (e.g. debritic textures, soft-sediment deformation, and sheared fabrics).

(iii) Evaluation of lateral variability within an MTD is critical in establishing its ability to act as a competent sealing unit. The MSB unit demonstrates a stark contrast between mud-rich debritic textures in the central and southern areas which are known to be sealing, and the northern area where injection fabrics may provide fluid conduits between disconnected reservoir units. This variability is also significant for reservoir development strategies and the prediction of fluid pressure cells between reservoir segments.

(iv) Transitional flows may preferentially form above mud-rich substrates such as the MSB, where turbulent flows are susceptible to becoming charged with cohesive mud. This produces an idealised stacking pattern with transitional flow deposits (e.g. banded and slurry beds) occurring directly above mud-prone MTDs or other mud-rich substrates.

(v) Transitional flow deposits have been shown to act as intermittent barriers or baffles to fluid flow. In the upper reservoir the deposits have compartmentalised the turbidite sandstone into sub-zones, significantly reducing sweep efficiency and enhancing early water breakthrough. Capturing these bed-scale heterogeneities during reservoir modelling is crucial for realistic reservoir flow simulation and an effective field development strategy.

\section{Acknowledgements}

We would like to thank Equinor, EnQuest, and Rocktype for their funding, access to data and general support throughout the project. The corresponding author would also like to thank Geological Society of London for research funding through the Daniel Pidgeon Fund. 
(a) Dip section

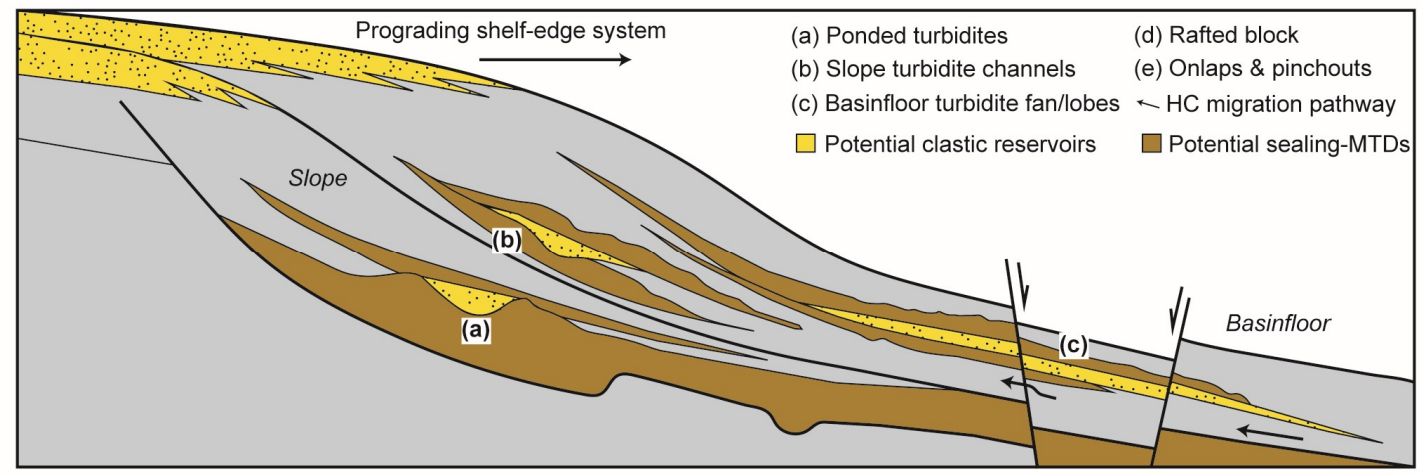

(b) Strike section

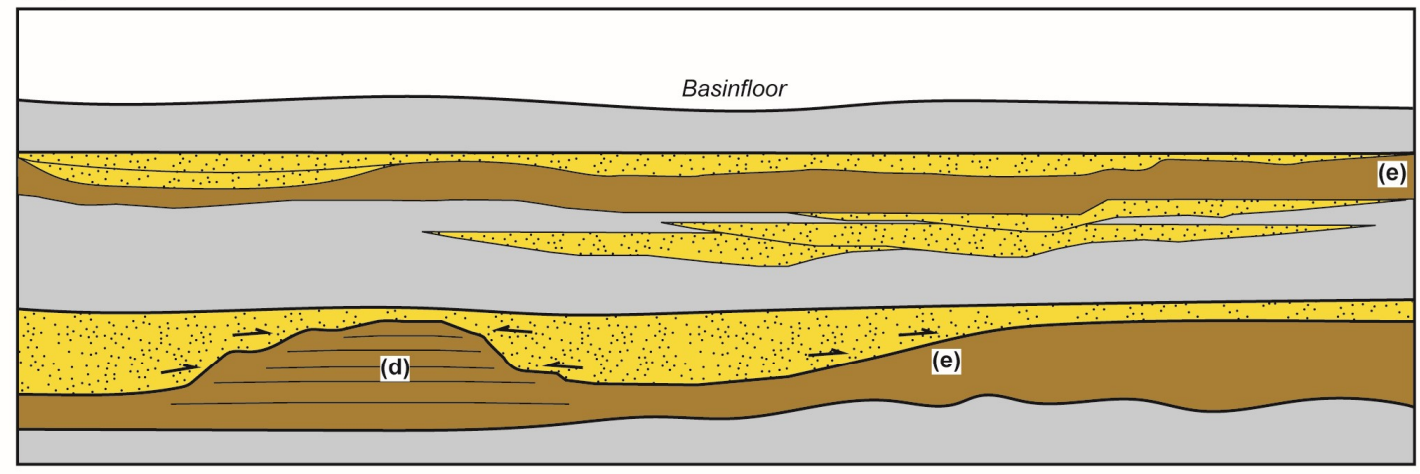

(c) Idealised pressure and petrophysical response

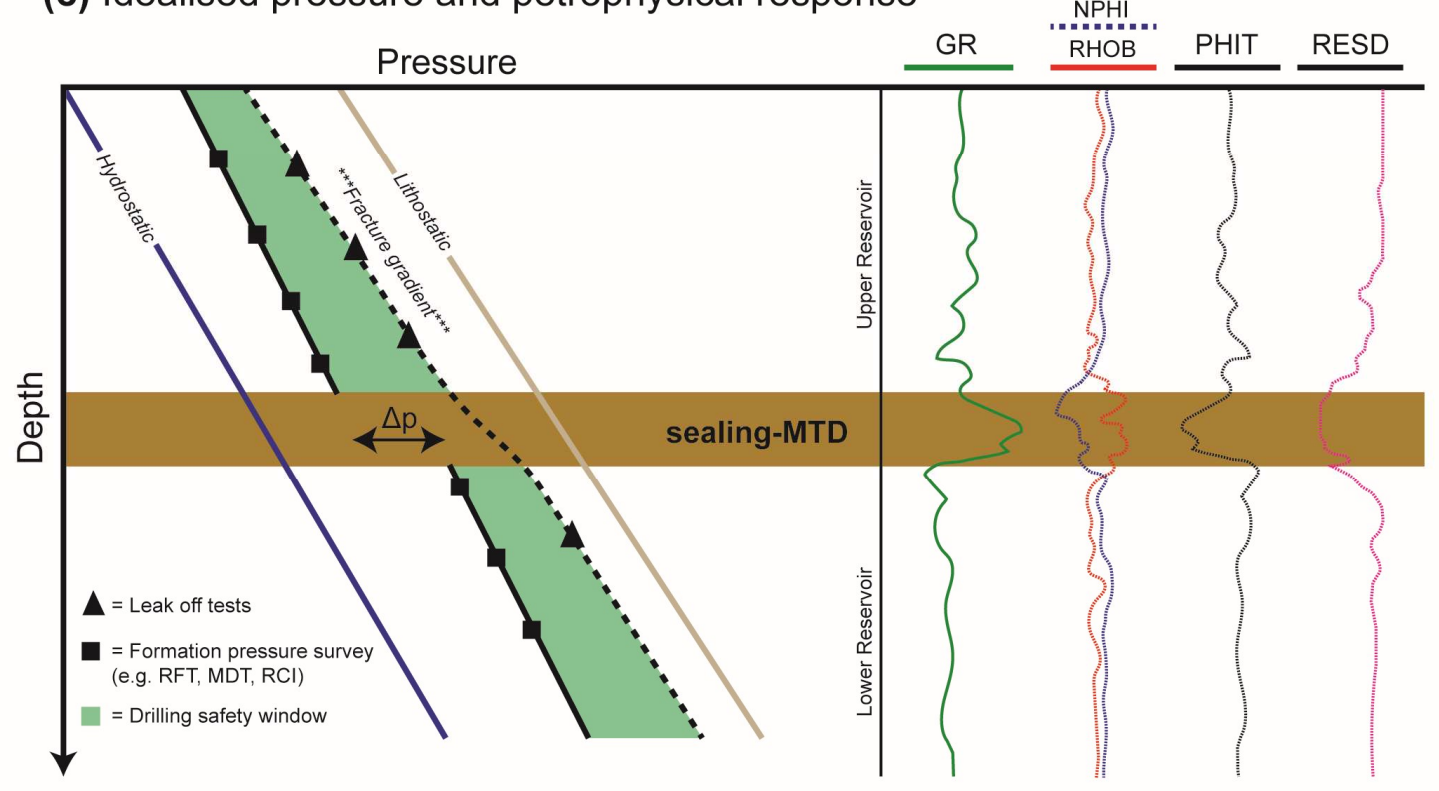

Fig.1 - Conceptual models of MTDs effect on reservoir and seal distribution, (a) dip section of shelf-slope-basinfloor transect with potential trapping mechanisms for turbidite slope channels, sheets, aprons, and basinfloor lobes from the Eocene shelfedge deltas, offshore Brazil (modified from Steventon et al. 2020), (b) strike section of MTD affecting lobe reservoir distribution, observed from Temburong Formation, NW Borneo and Tres Paso Formation, Southern Chile (modified from Jackson \& Johnson 2009, Armitage \& Jackson 2010) (c) idealised formation pressure and petrophysical responses of a sealing-MTD. 


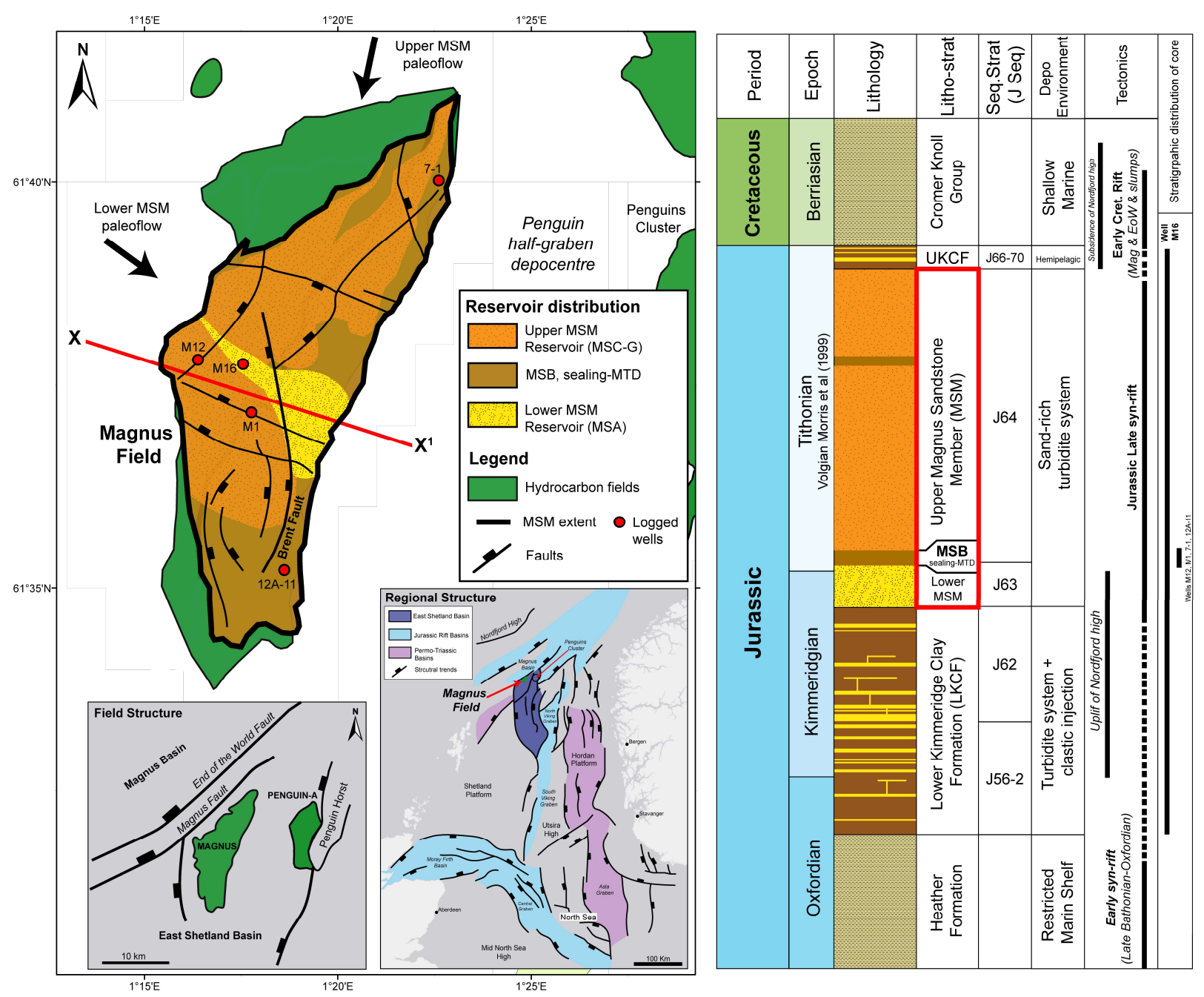

Fig.2 - (Left) Reservoir distribution map of the Magnus Field, note inset maps with field location in relation to the wider structural framework, (Right) northern North Sea stratigraphic column of the Jurassic-Cretaceous, with studied section highlighted in red. Volgian is a regional term approximately equivalent to the Tithonian. Collated from Shepherd et al. (1991), Partington et al. (1993), Morris et al. (1999), Al-Abry (2002), and Dominguez et al. (2007). 

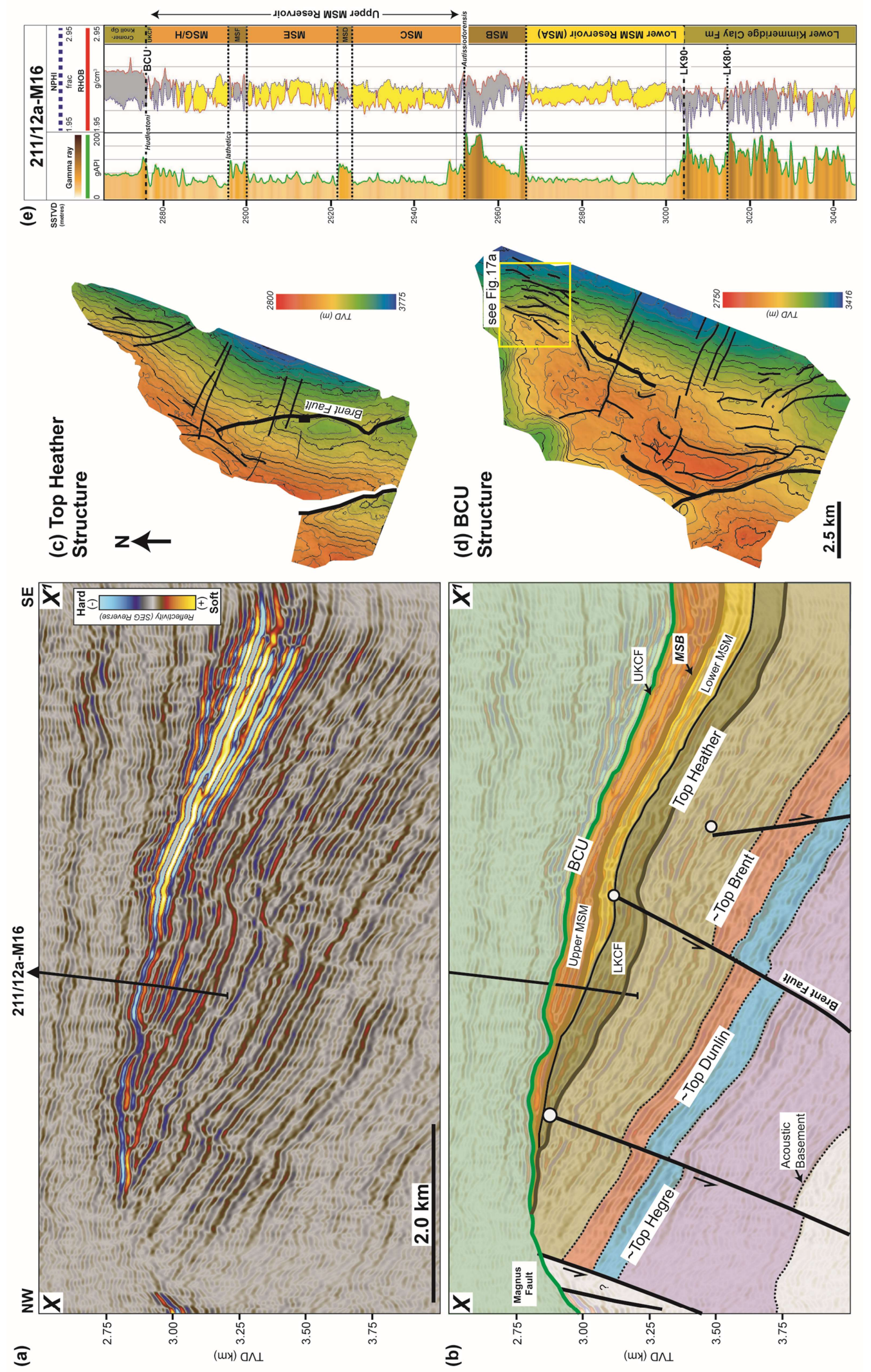

Fig.3: Field overview, (a) seismic dip section through the field (note: location X-X' found in Fig.2a), (b) geoseismic section of principle seismic-stratigraphic units, note updip pinch-out and truncation of the MSM into the BCU, highlighting the combination structural-stratigraphic trap, (c) Top Heather depth structure map with major normal fault arrays, (d) BCU depth structure with late-syn rift normal faults and MTD headwall scarps and slump faults (see Fig. 17a), (e) summary of reservoir units MSA to MSH from well 211/12a-M16. 
(a) MSM Log (well M16)

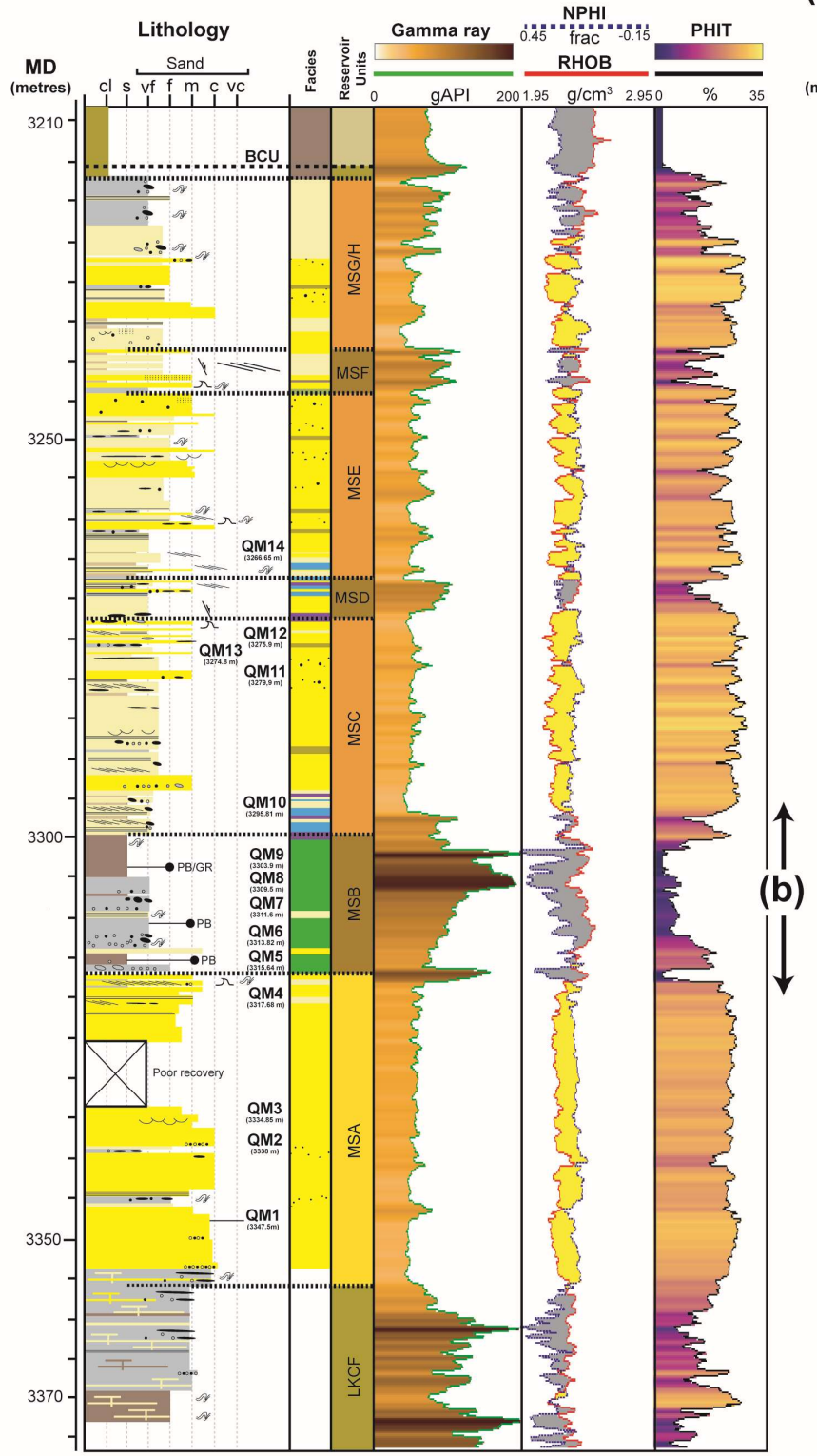

(b) MTD Facies

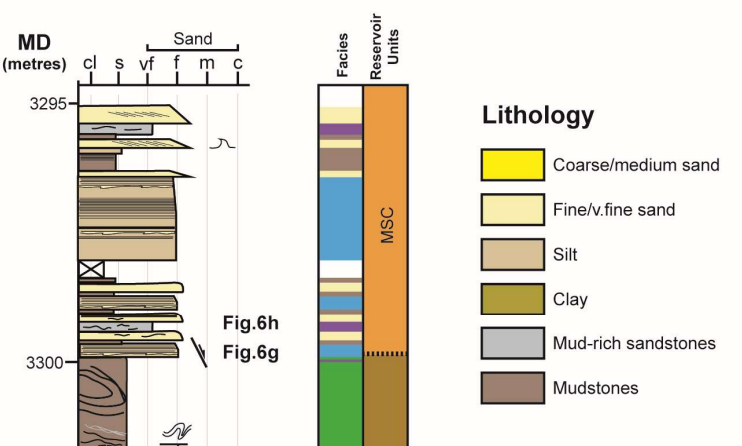

Facies (see Table 1)

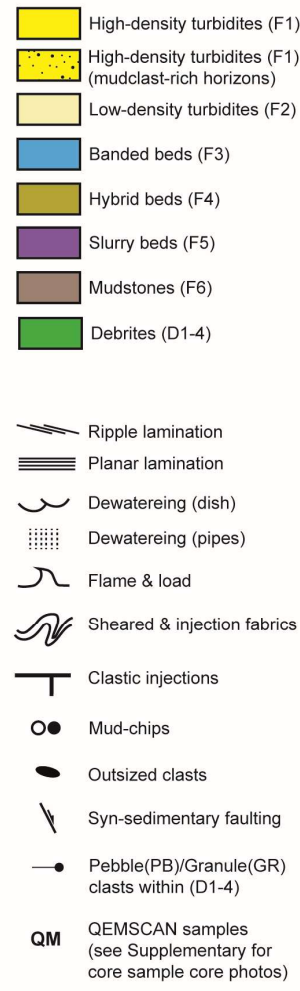

Fig.4: (a) Summary core logging sheet from 211/12a-M16 with main lithologies, reservoir units, and petrophysical responses. Note positions of samples (QM) taken for QEMSCAN analysis. RHOB = bulk density, NPHI= neutron porosity, PHIT = total porosity. (b) Detailed log of the MSB unit from well 211/12a-M16, note depths of core photos in Figure 6 \& 7. 

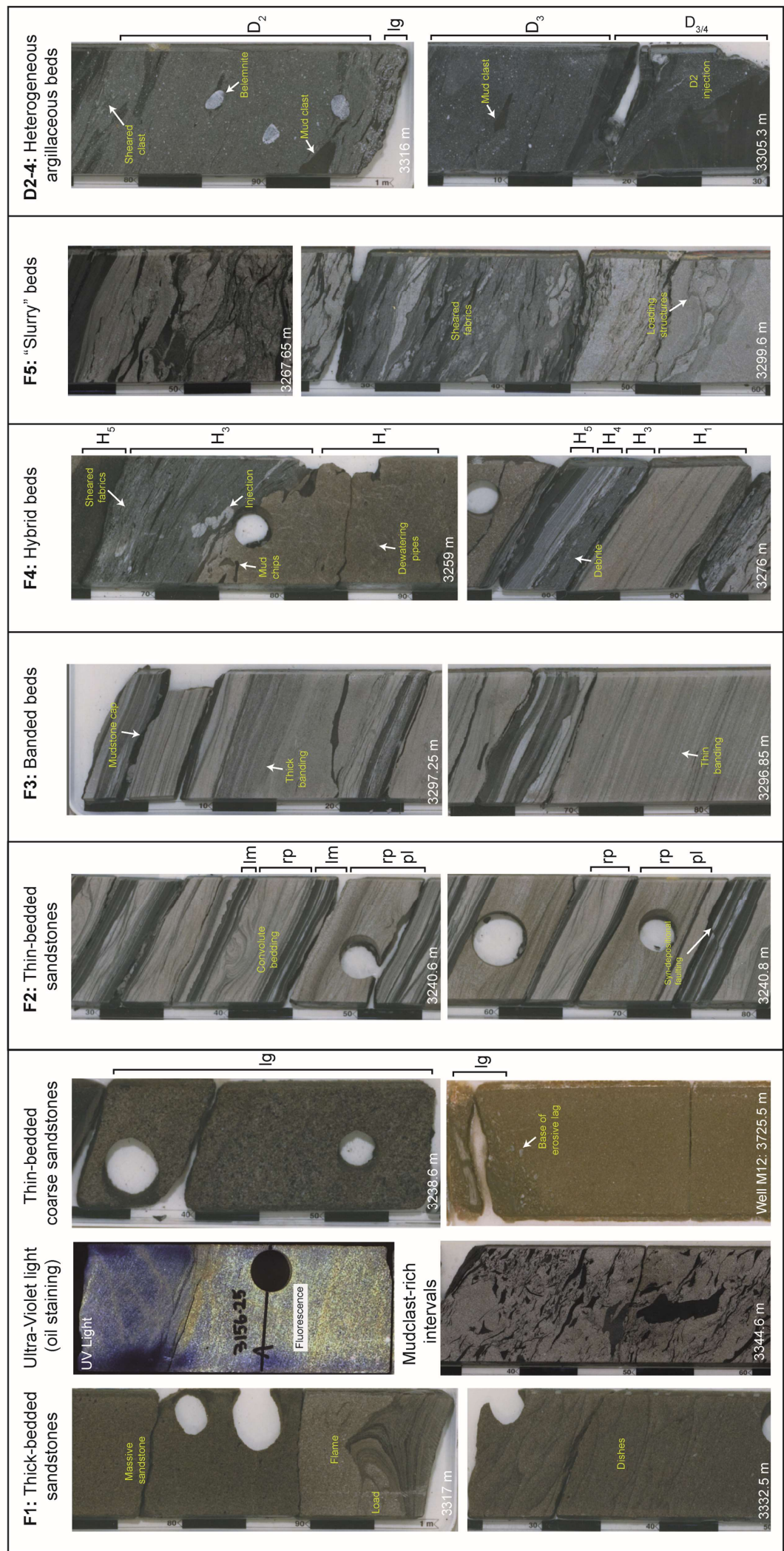

Fig.5: Summary of turbidite (F1-2), transitional (F3-4), and debrite (D2-4) core facies observations. 


\section{Longitudinal flow transformation}

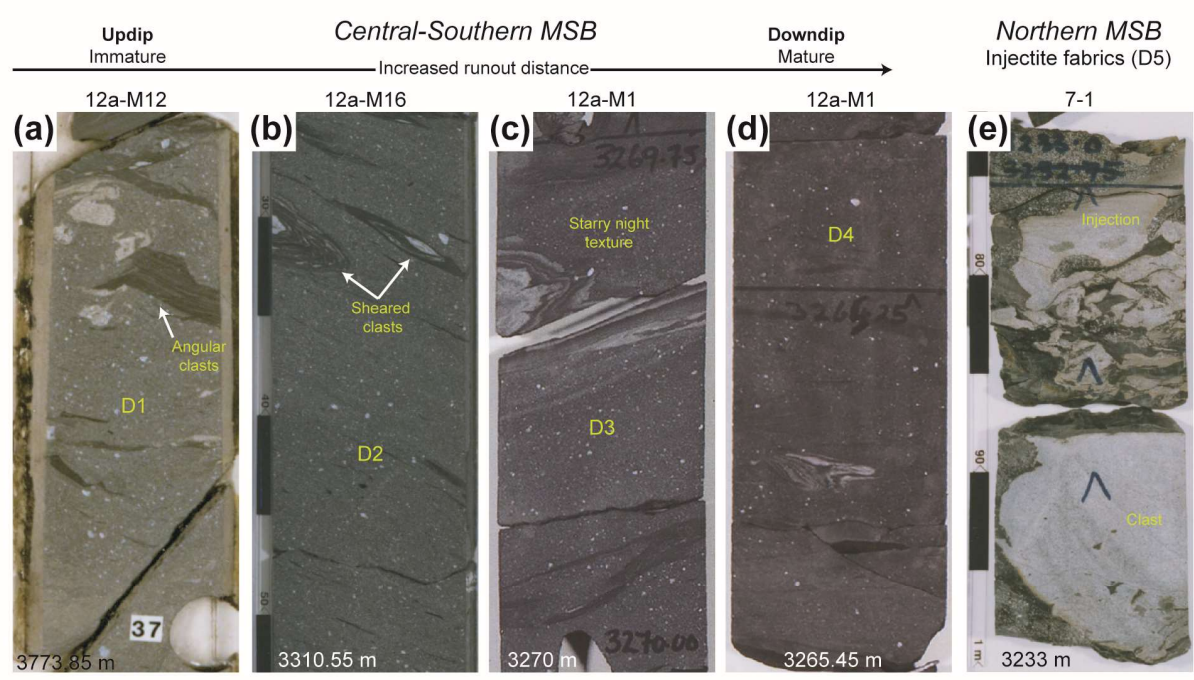

\section{Transition from MSB to MSC}
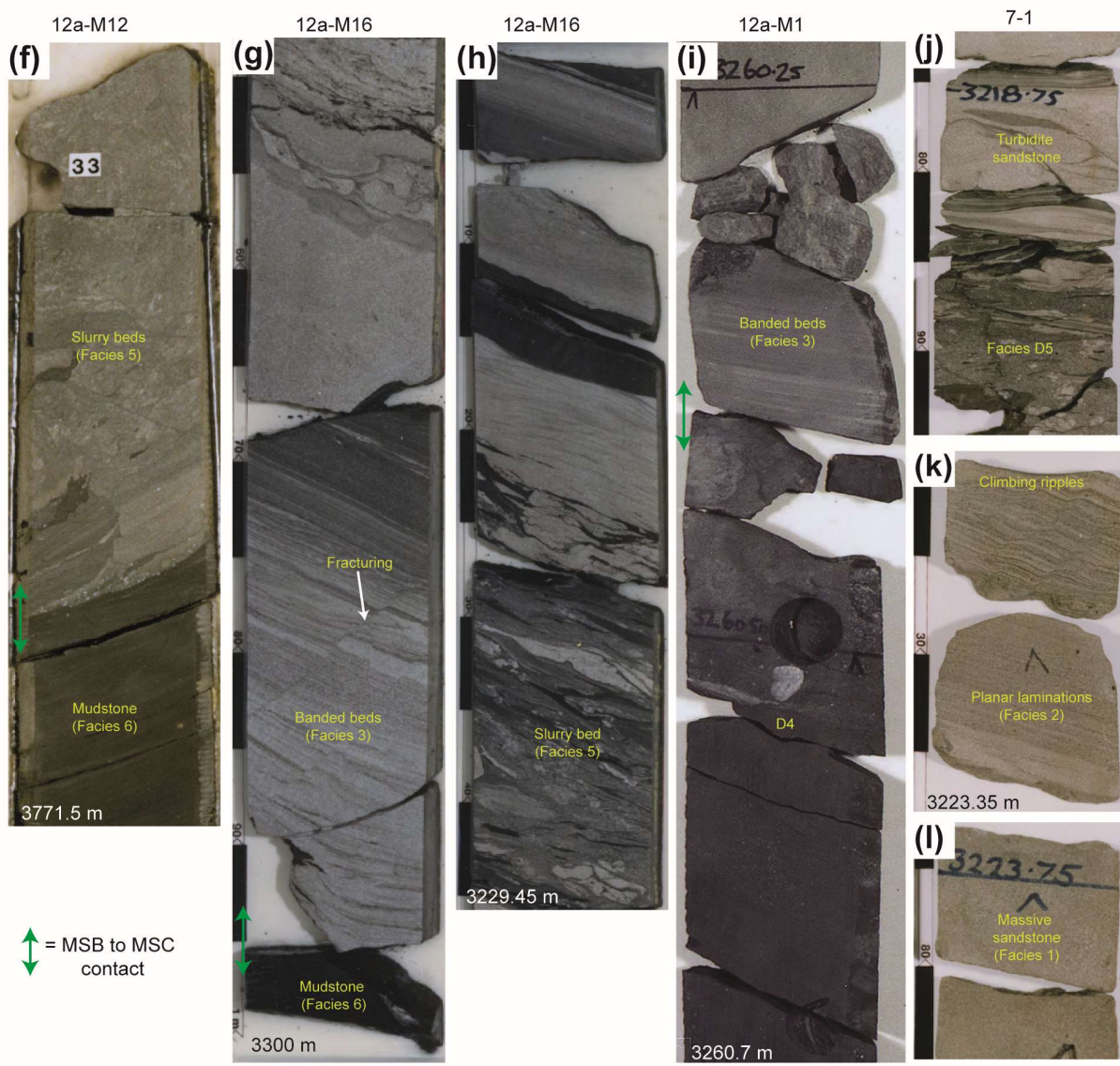

Fig.6: (a-d) core photos of the downslope longitudinal flow transformation of Facies D1-4 from sand-rich to clay-rich, (e) core photo of facies D5 (see Table 2), (f-l) observations of the transition between MSB and MSC. Note green arrows marking the contact, well 7-1 contact was not recovered during coring. 

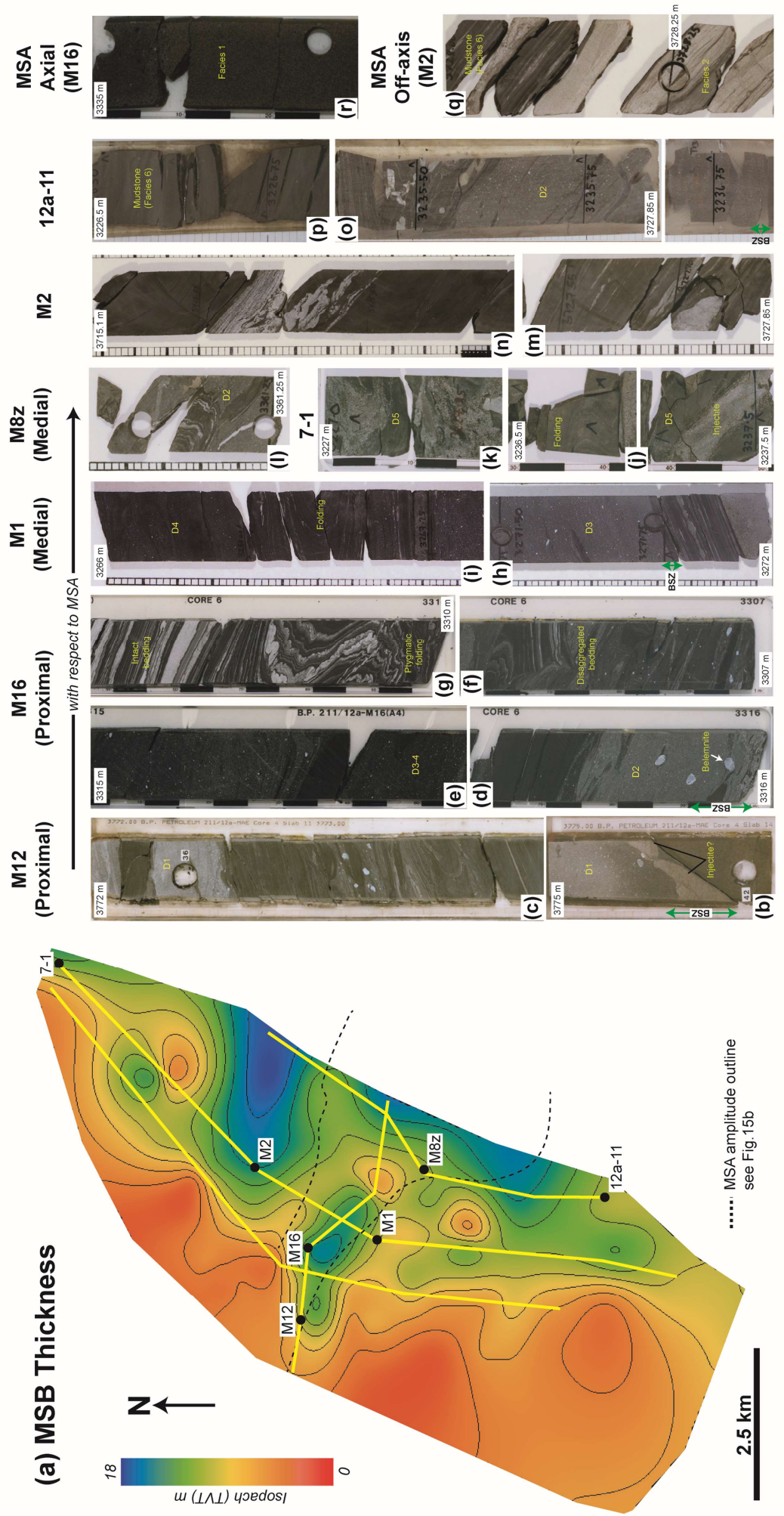

Fig.7: (a) MSB thickness calculated from formation tops from wells, note the correlation between thickness and the outline of the underlying MSA unit. (c-p) core photos capturing the heterogeneity within the MSB units. Note the basal shear zone (BSZ) or contact between the MSA and MSB is marked by a green arrow, $(r-q)$ example of axial and off-axis MSA. 
(a)

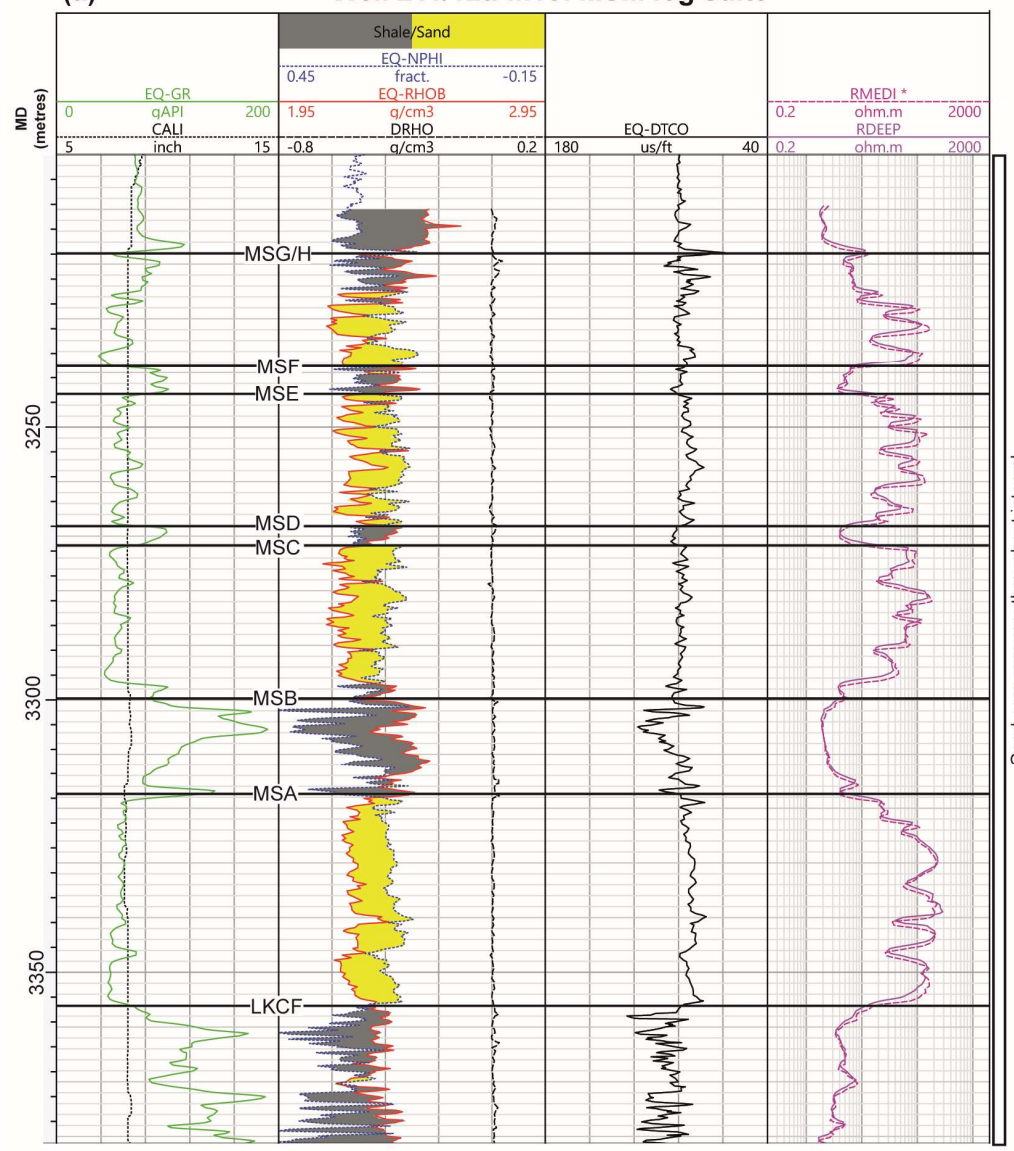

(b)

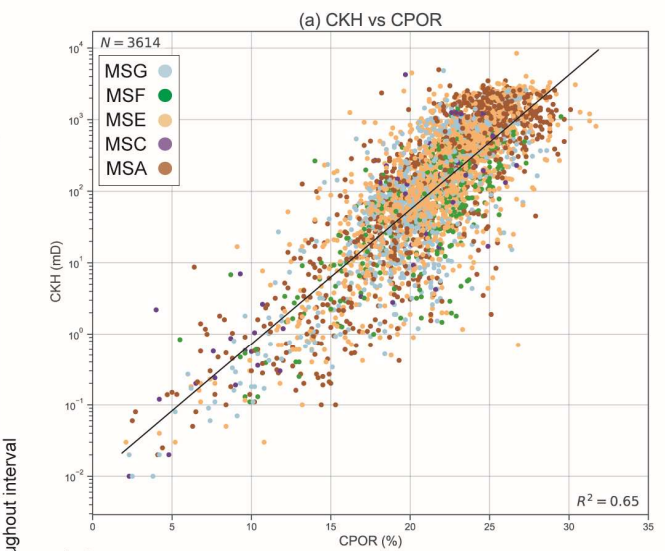

(c)

(b) CKV vs CPOR

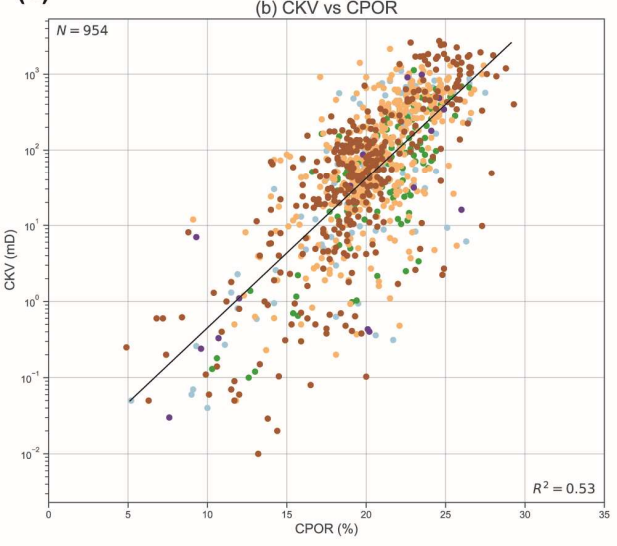

Fig.8: (a) Petrophysical log suite from 211/12a-M16 summarising the Magnus Reservoir, from left to right, GR = gammaray, $C A L I=$ calliper, $N P H I=$ neutron porosity, $R H O B=$ bulk density, $D R H O=$ density correction, DTCO = compressional (sonic) velocity, RMEDI = medium resistivity, RDEEP = deep resistivity. (b) horizontal core permeability vs. core porosity, and (c) vertical core permeability vs. core porosity. 
(a) Central dip

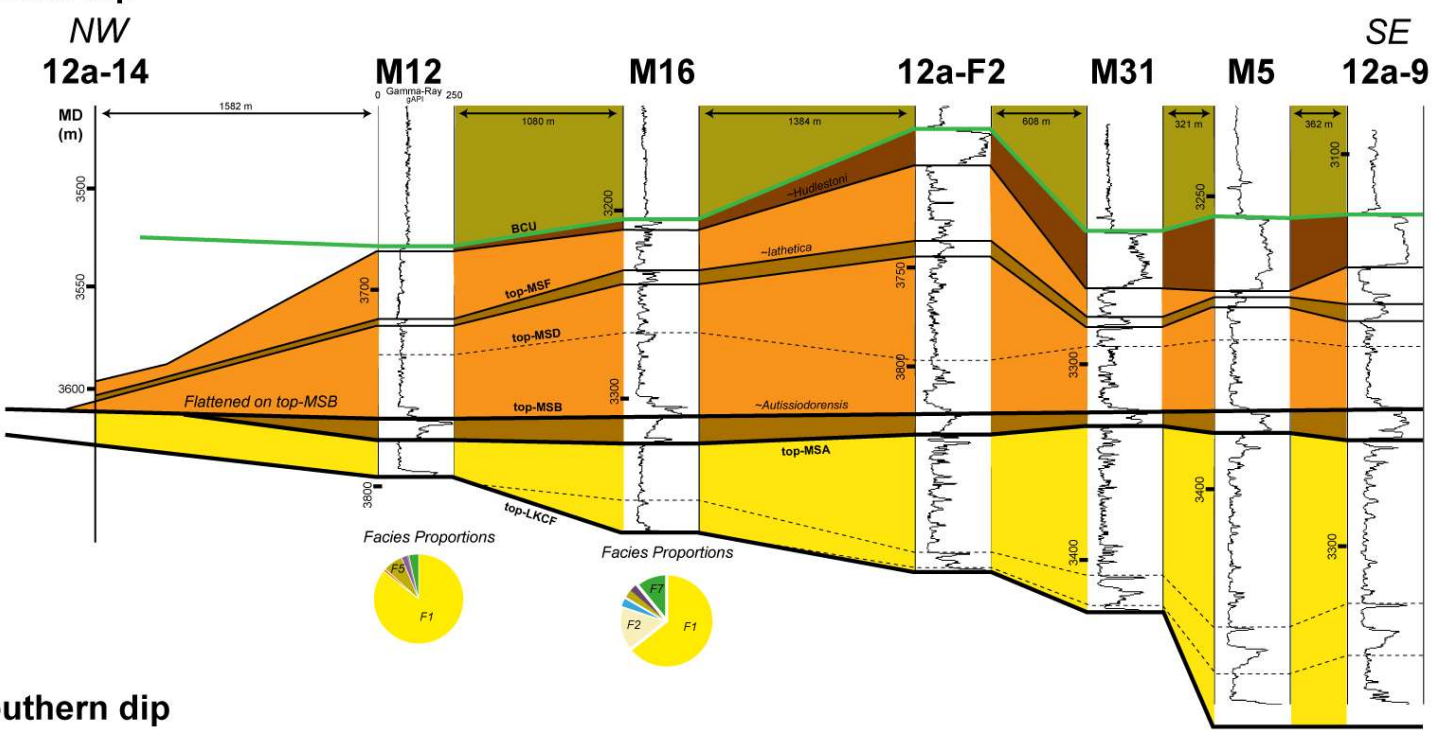

(b) Southern dip

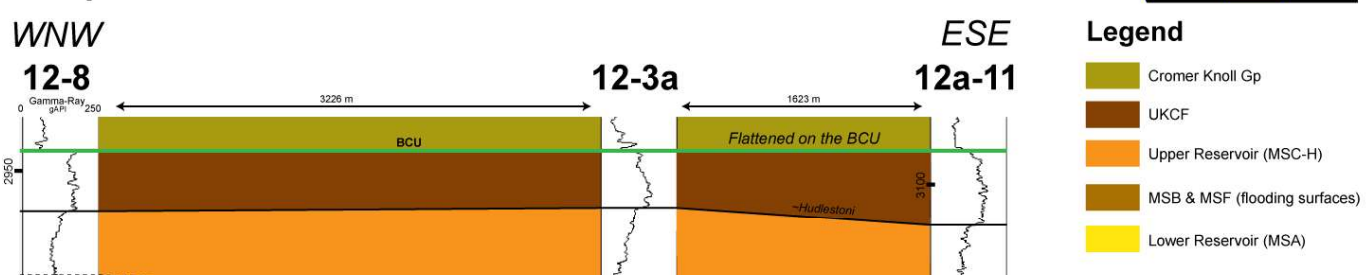

Biostratigraphy

Hualestoni (top $\sqrt{ }(64)$ - maximum flooding sufface

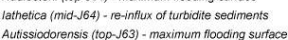

Facies Proportions

High-density turbidites (F1)

Low-density turbidites (F2)

Banded beds (F3)

Hybrid beds (F4)

(c) Northern dip

Facies Proportion

Slurry beds (F5)

Mudstones (F6)
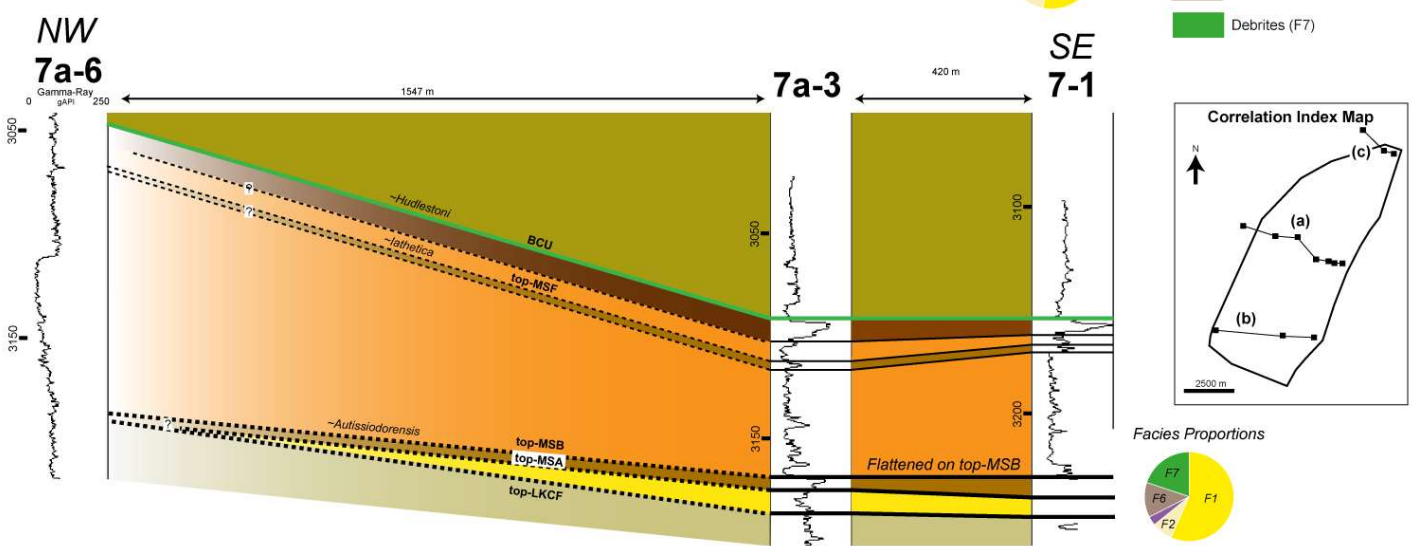

Facies Proportions 


\section{(d) Upper slope}

SW

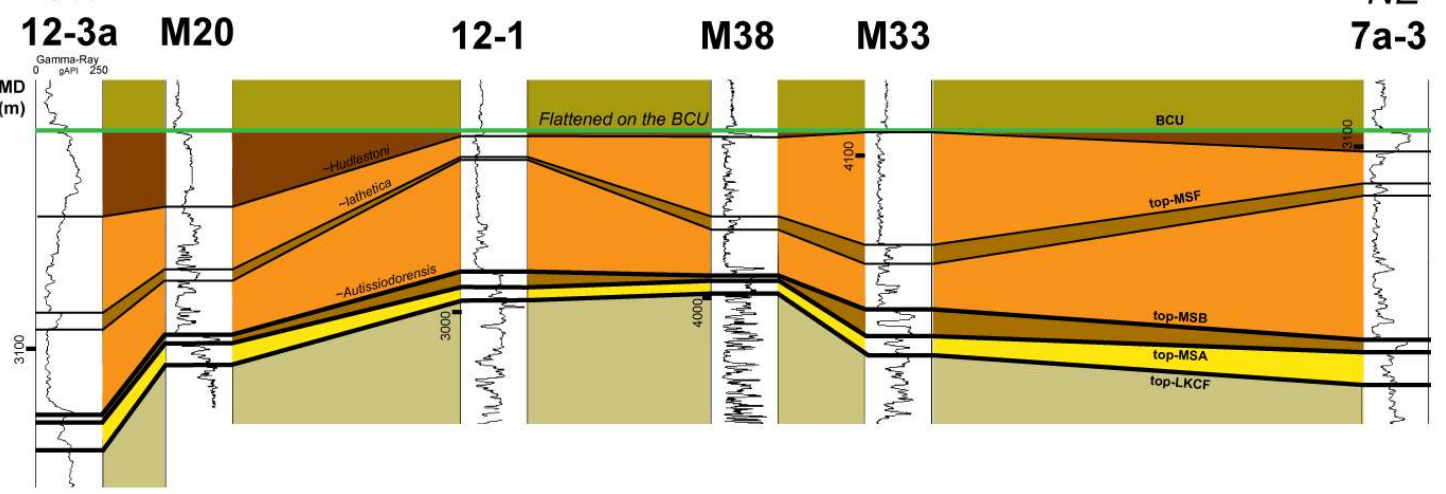

(e) Mid slope

\section{SW}

12a-12a 12a-13

$N E$

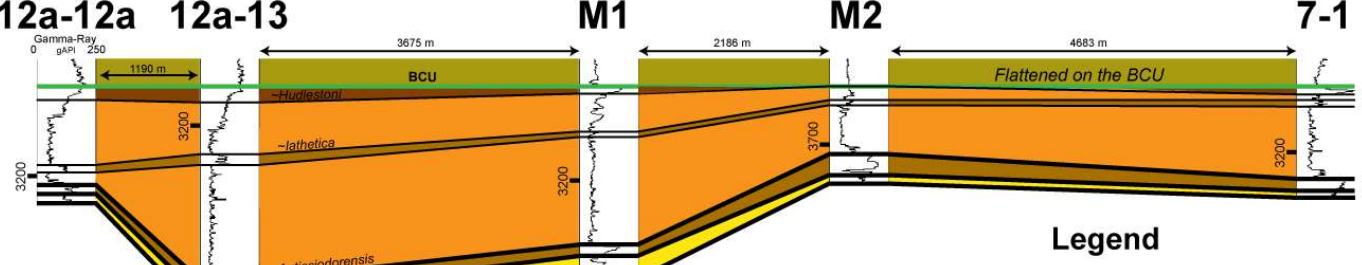

Facies Proportions

(f) Base of slope

SW

12a-11

\section{M3}

$A_{F 2}^{F}$
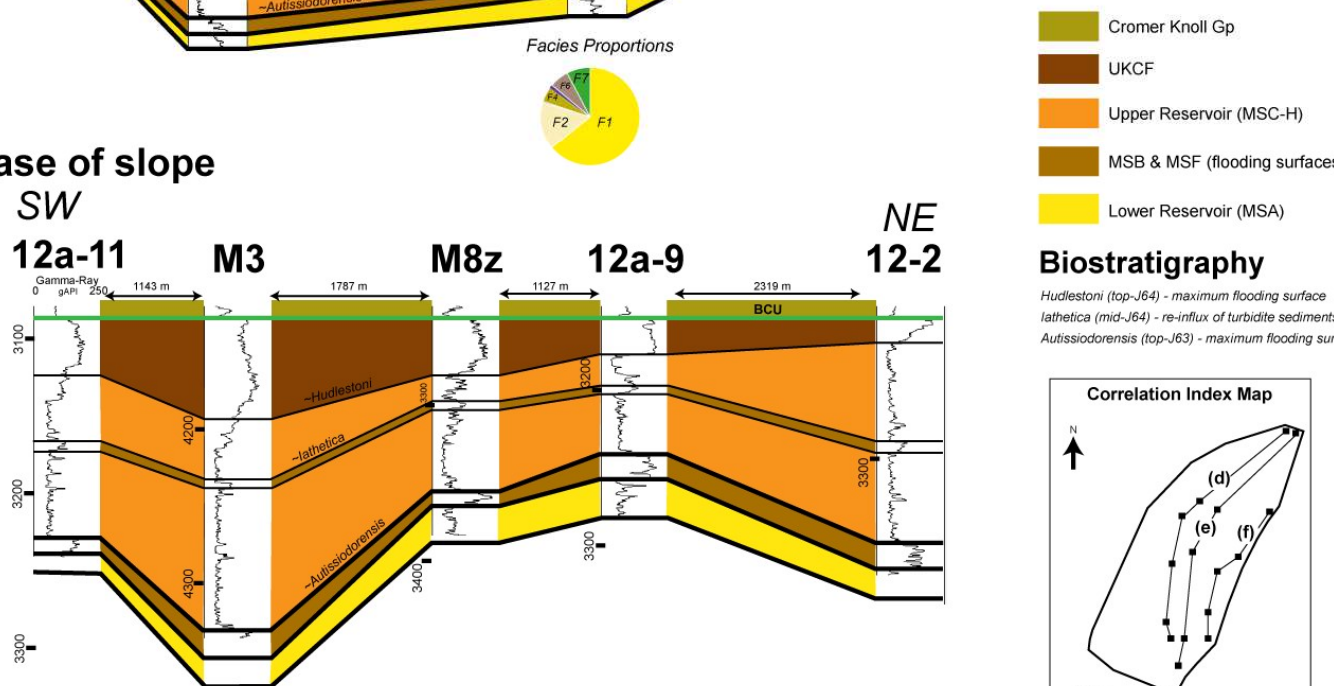

$N E$

Lower Reservoir (MSA)

\section{Biostratigraphy}

Hudlestoni (top-J64) - maximum flooding surface Autissiodorensis (top-V63) - maximum flooding surface

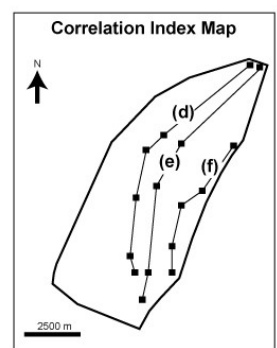

Fig.9: Reservoir correlation panels, (a-c) downdip correlations, (d-f) along-strike correlations. Note facies proportions in logged wells, and biostratigraphic markers Autissiodorensis, Iathetica re-influx, and Hudlestoni. 
(a) Formation pressure plots

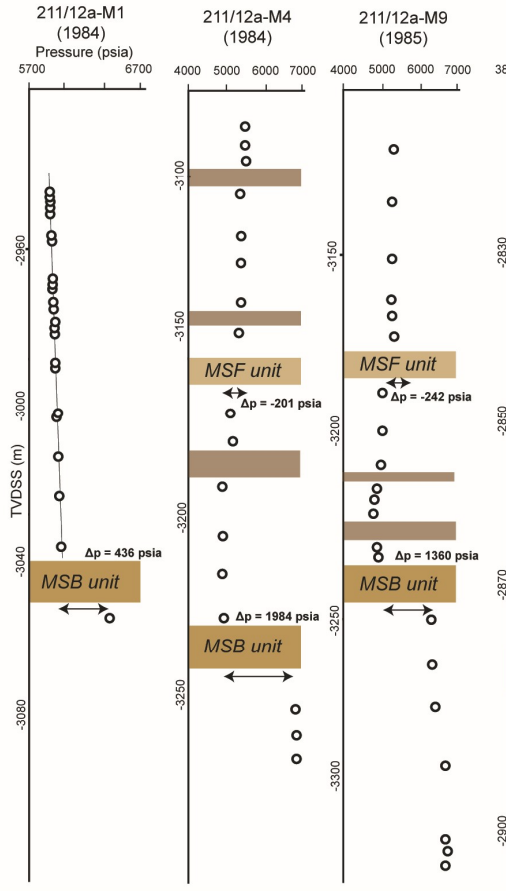

211/12a-M12 211/12a-M16 $\begin{array}{lrl}(1986) & (1991)\end{array}$

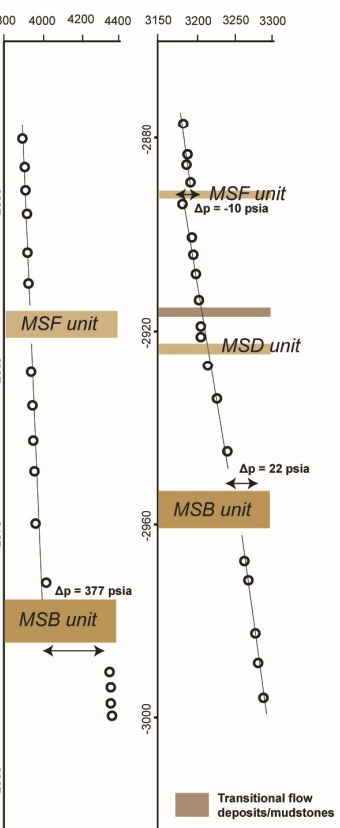

(b) Change in pressure between MSA-MSC

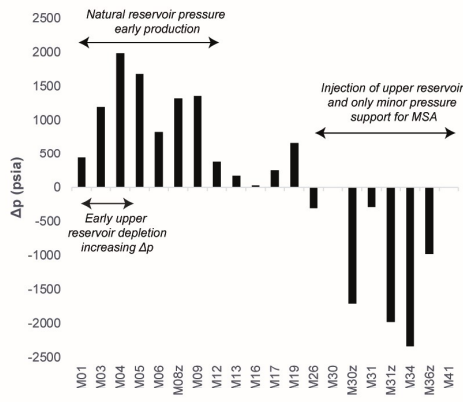

(c) Pressure vs MSB thickness

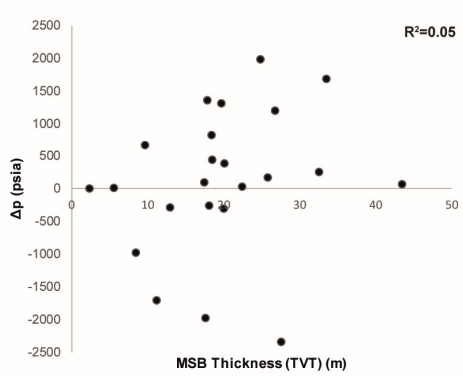

(d) Production history

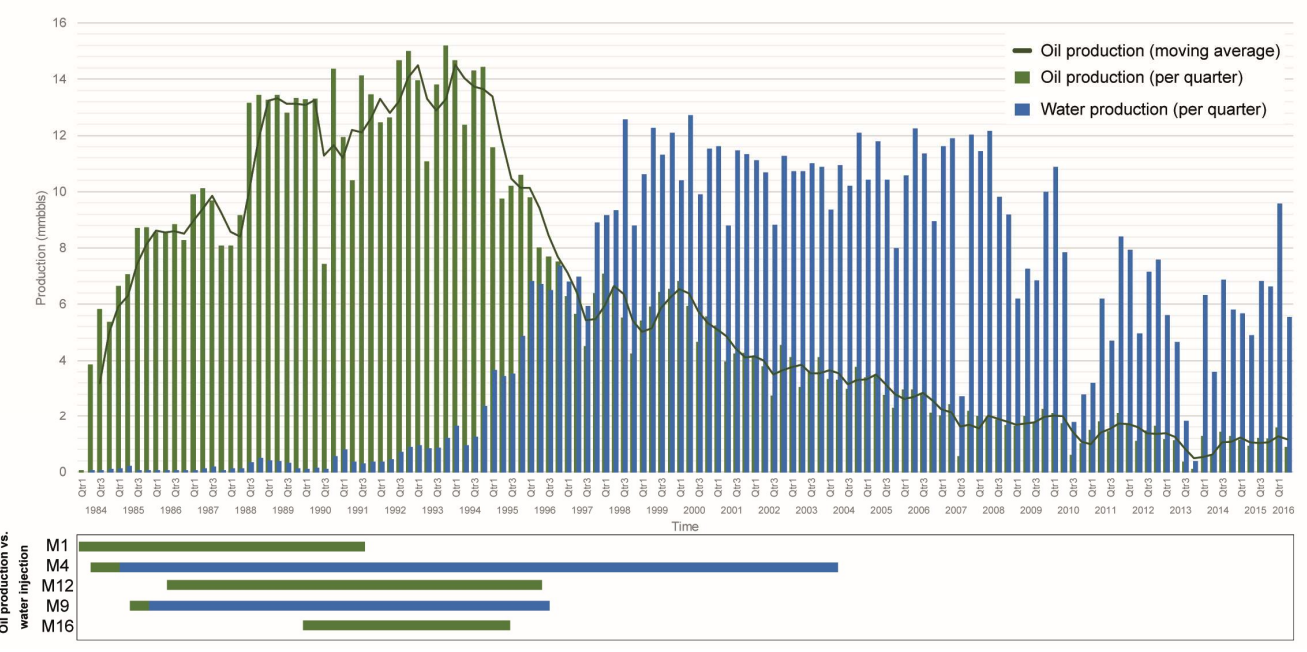

Fig.10: (a) formation fluid pressure plots, note pressure break associated with MSB, MSD, MSF and isolated transitional flow deposits, (b) change in pressure observed between MSA and MSC, (c) plot of change in pressure between MSA and MSC vs. MSB thickness, (D) production profile of the Magnus Field, including both oil production and water production (cut), note activity timelines of wells. 


\section{Turbulent Facies}
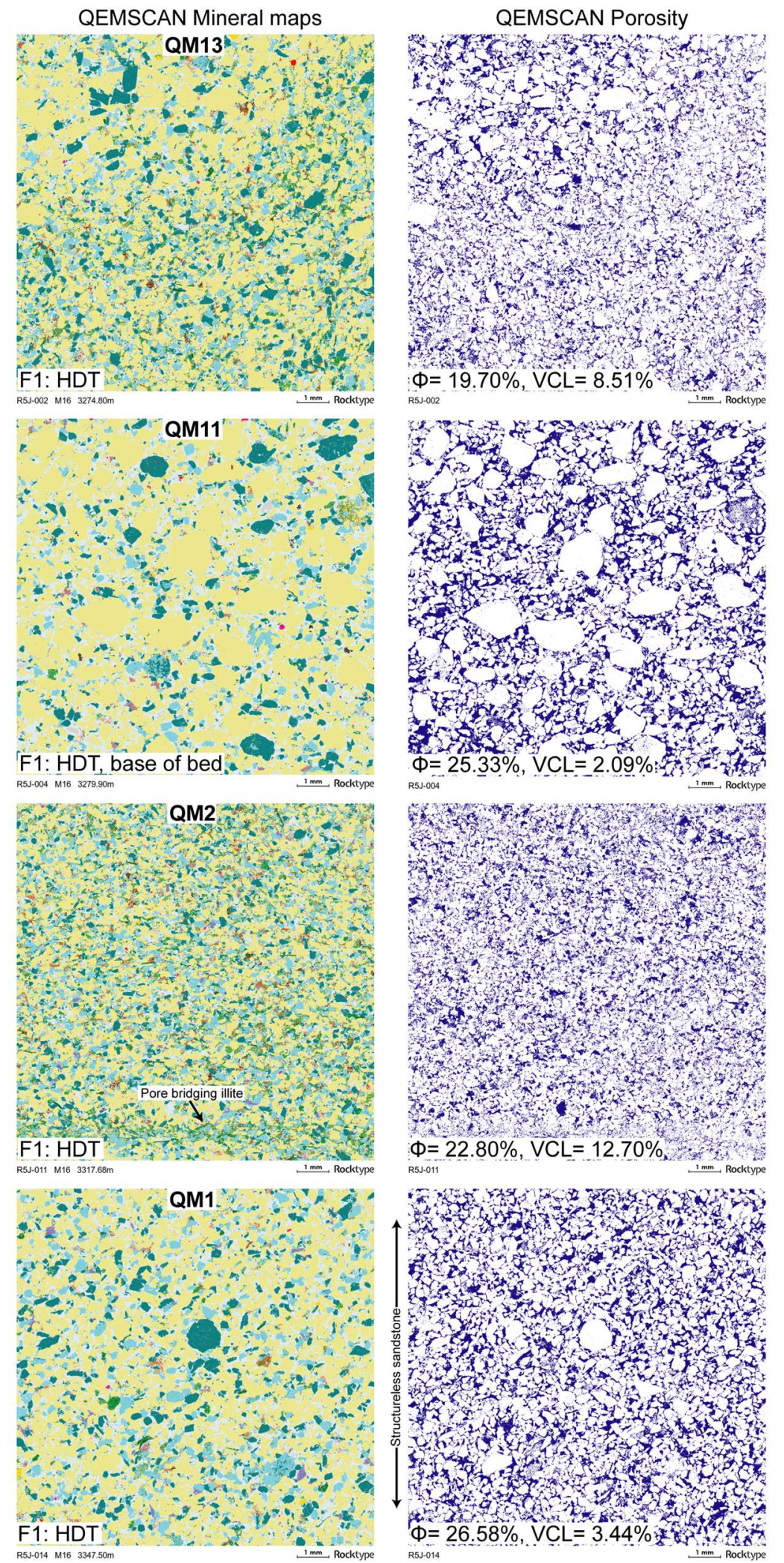

$\Phi=22.80 \%, V C L=12.70 \%$ \% 25 .

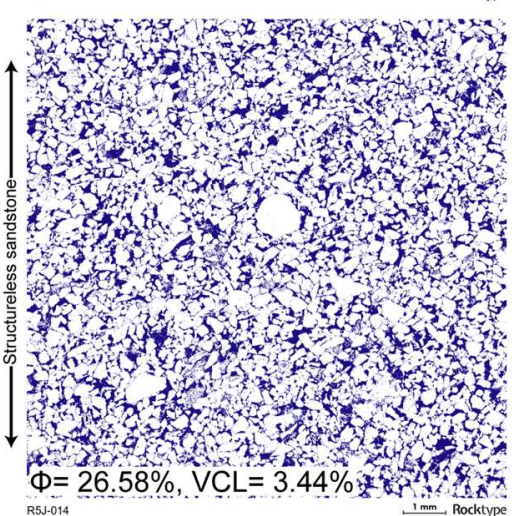

Mineral index

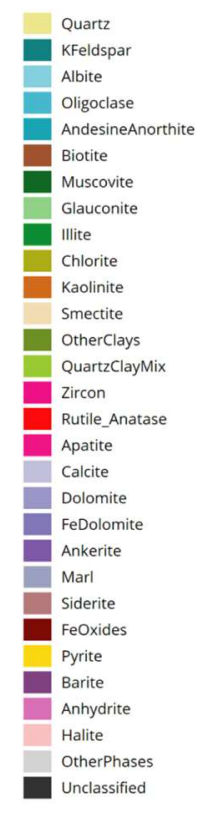

Fig. 11. Mineral maps and related porosity extractions of turbidite facies $(H D T=$ high-density turbidites, VCL $=$ volume of clay). Field of view $=2 \times 2 \mathrm{~cm}$. 


\section{Laminar/Transitional Facies}
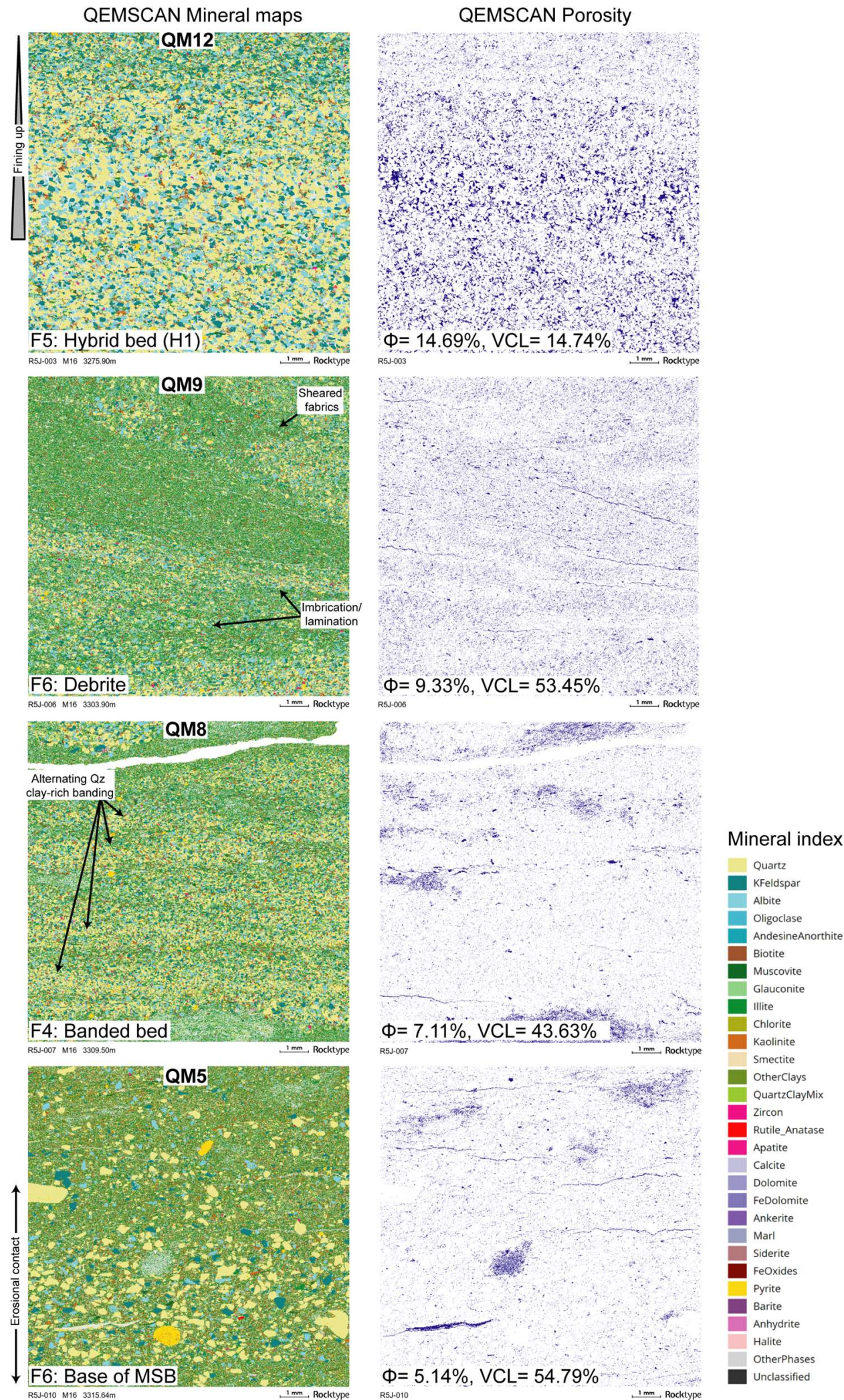

Fig. 12. Mineral maps and related porosity extractions of laminar and transitional flow deposits (VCL = volume of clay). Field of view $=2 \times 2 \mathrm{~cm}$. 
Grain Size Distribution

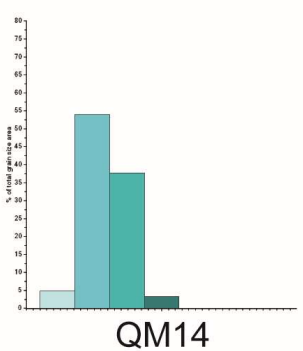

(Low-density turbidite)

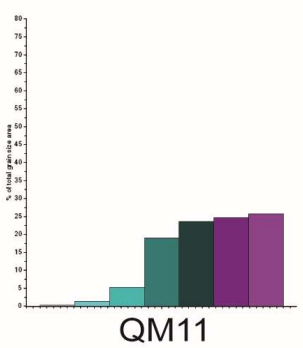

(High-density turbidite near base of bed)

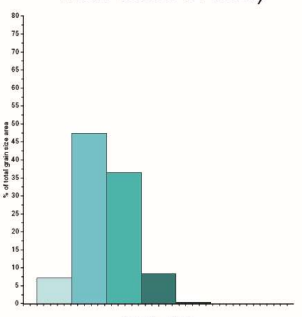

QM8

(Banded bed block within MSB)

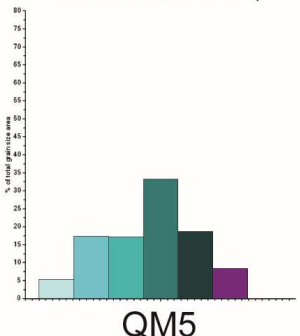

(Debrite D2-4 at base of MSB)

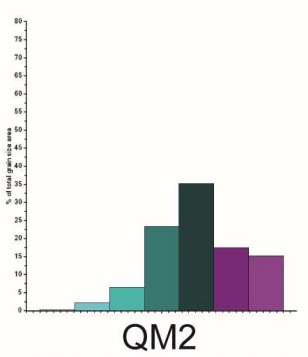

(High-density turbidite)

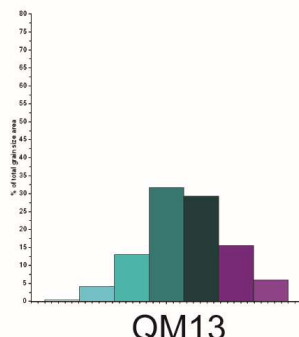

(High-density turbidite)

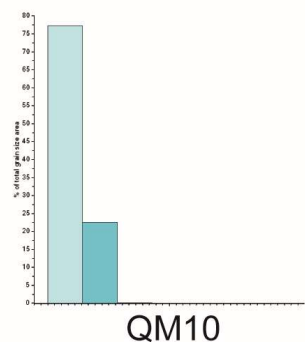

(Low-density turbidite)

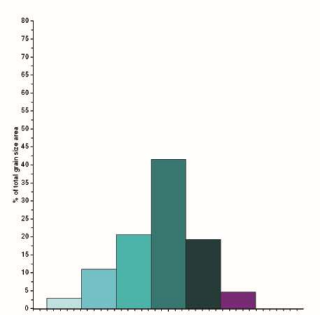

QM7

(Debrite D2-4)

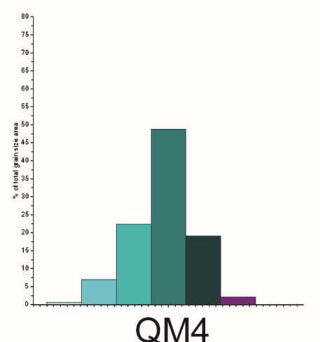

(High-density turbidite)

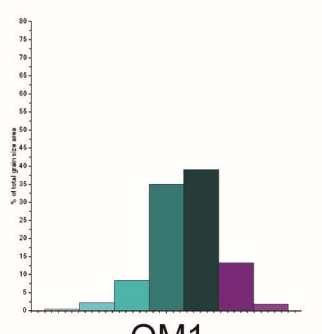

QM1

(High-density turbidite)

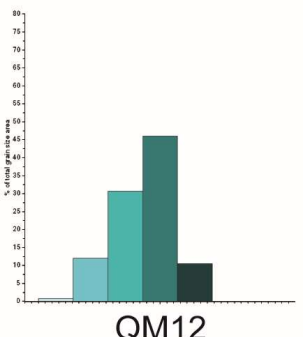

(Hybrid-bed (H1))

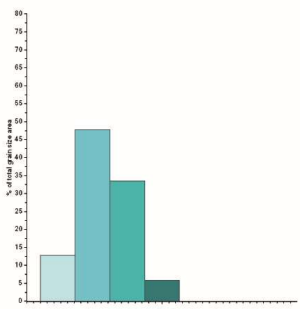

QM9

(Debrite D2-4)

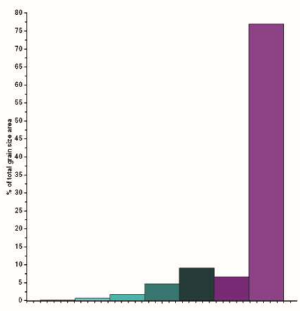

QM6

(High-density turbidite block within MSB)

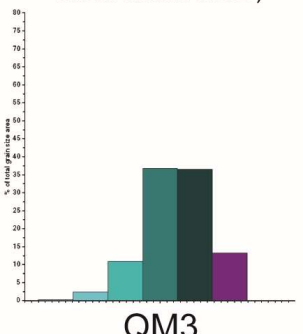

(High-density turbidite)

Grain size $(\mu \mathrm{m})$

Clay-Silt (f) $\square \quad 1-20$

Silt $(m-c) \square 20-63$

vf $\square$ 63-125

f $\square 125-250$

Sand $m \square 250-500$

C $\square 500-1000$

vc $1000+$

Fig.13: Grain-size distribution of quartz phases extracted from the QEMSCAN samples QM1-14 (see Fig. 4a for sample depths within well M16). 

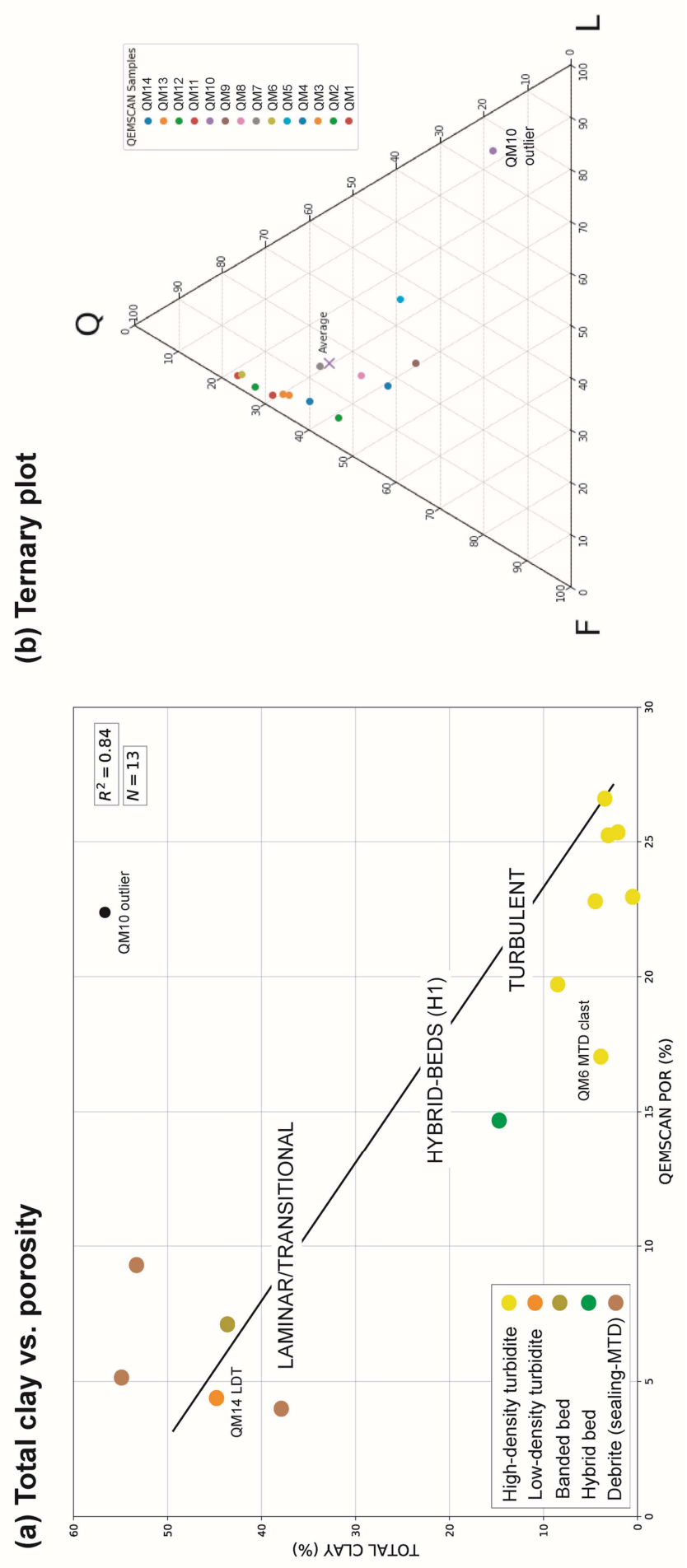

Fig.14: (a) QEMSCAN total volume of clay vs. porosity, note linear relationship, with turbulent facies having low clay and high porosity values and debrites having high clay and low porosity values, (b) quartz-feldspar-lithics ternary plot of QEMSCAN samples generally clustering around sub-arkose, arkose, lithic arkose, and feldspathic litharenite categories. 


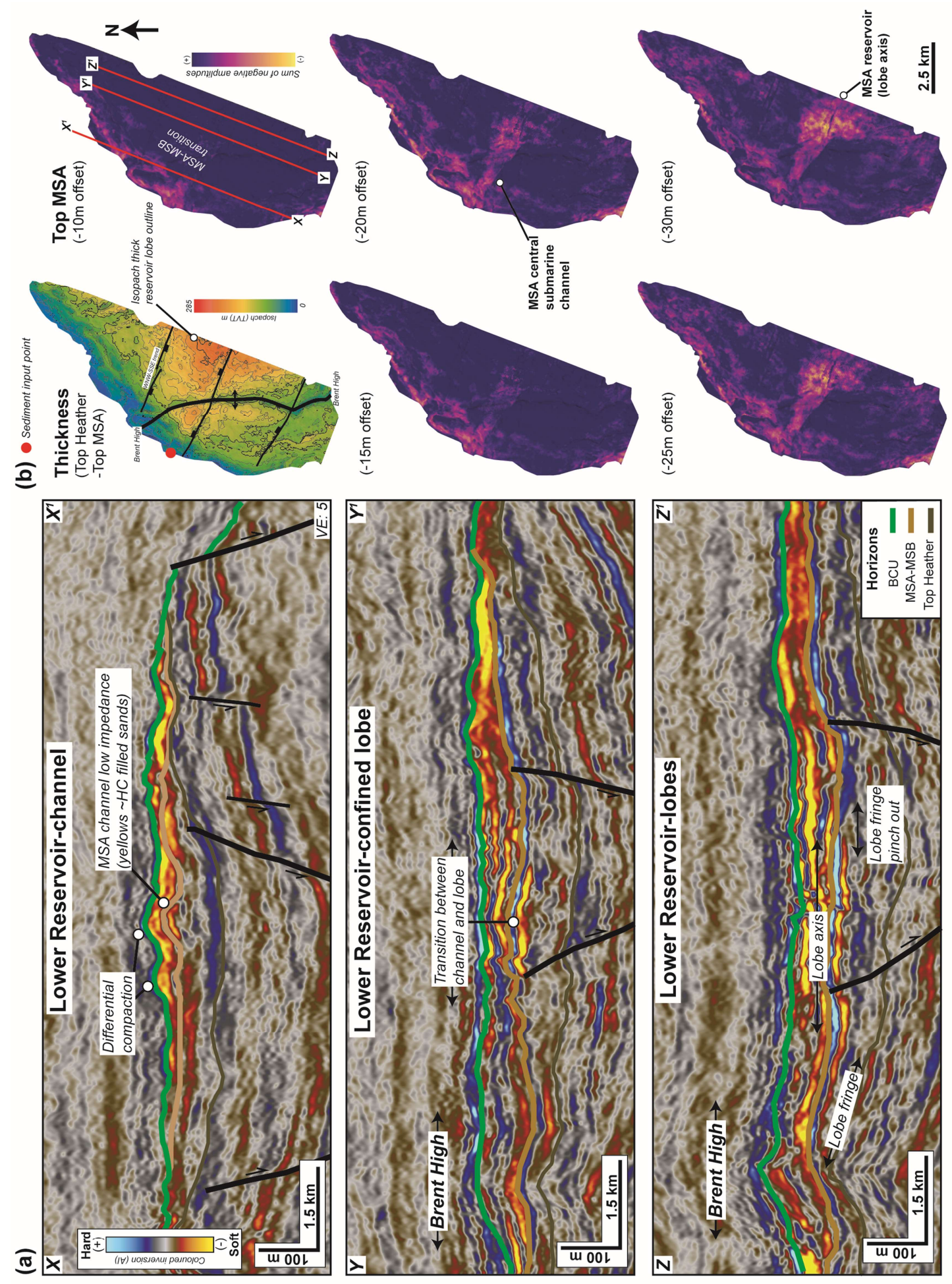

Fig.15: (a) strike-orientated seismic sections imaging the evolution of the lower reservoir (MSA) from a confined updip channel to distributive lobe complexes downdip, note sections are displayed using a coloured inversion cube, with high (hard) acoustic impedances = blue, and low (soft) acoustic impedance = yellow, (b) thickness map highlighting the central isopach thick of the lower reservoir, with sum of negative amplitude extractions highlighting the geometry and evolution of the MSA reservoir channel-lobe system. 

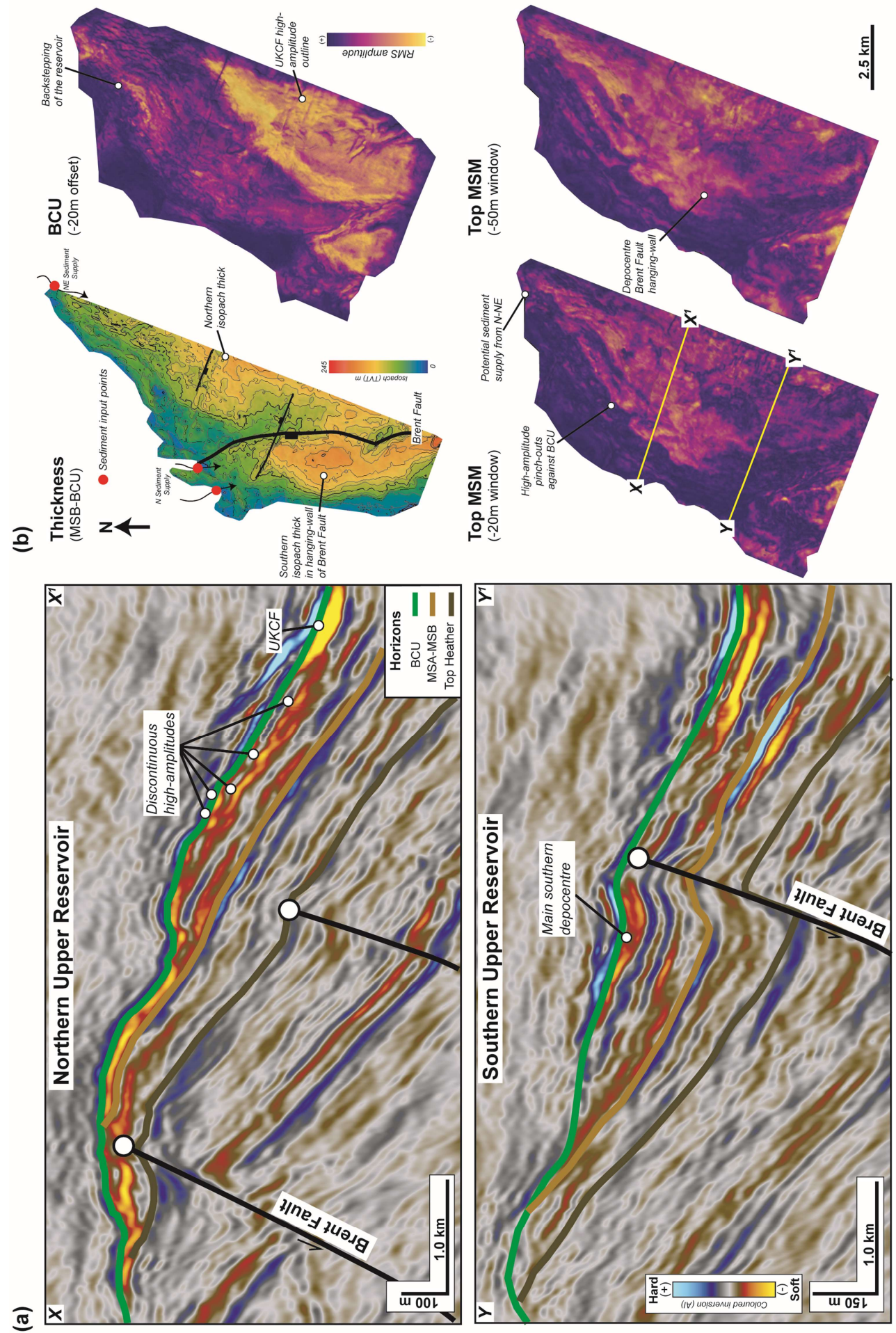

Fig.16: (a) dip-orientated seismic sections highlighting the evolution of the upper reservoir (MSC-H), with the central section (X-X1) imaging the depocentre to the north of the Brent Fault High, and the southern section (Y-Y1) imaging the syndepositional depocentre south of the high, note sections are displayed using a coloured inversion cube, with high (hard) acoustic impedances $=$ blue, and low (soft) acoustic impedance = yellow, (b) thickness map highlighting the southern and northern isopach thicks, with RMS amplitude extractions highlighting the geometry and evolution of the upper reservoir and the Upper Kimmeridge Clay Formation (UKCF). 
(a)

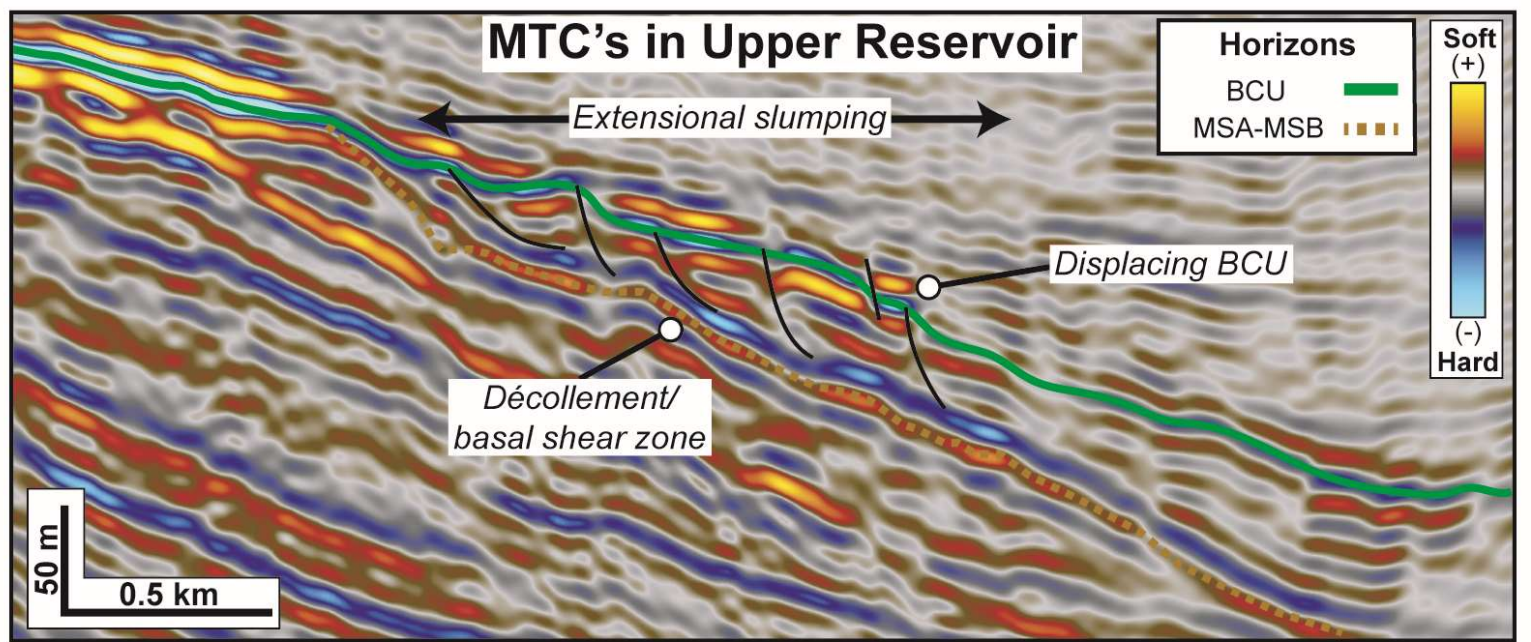

(b)

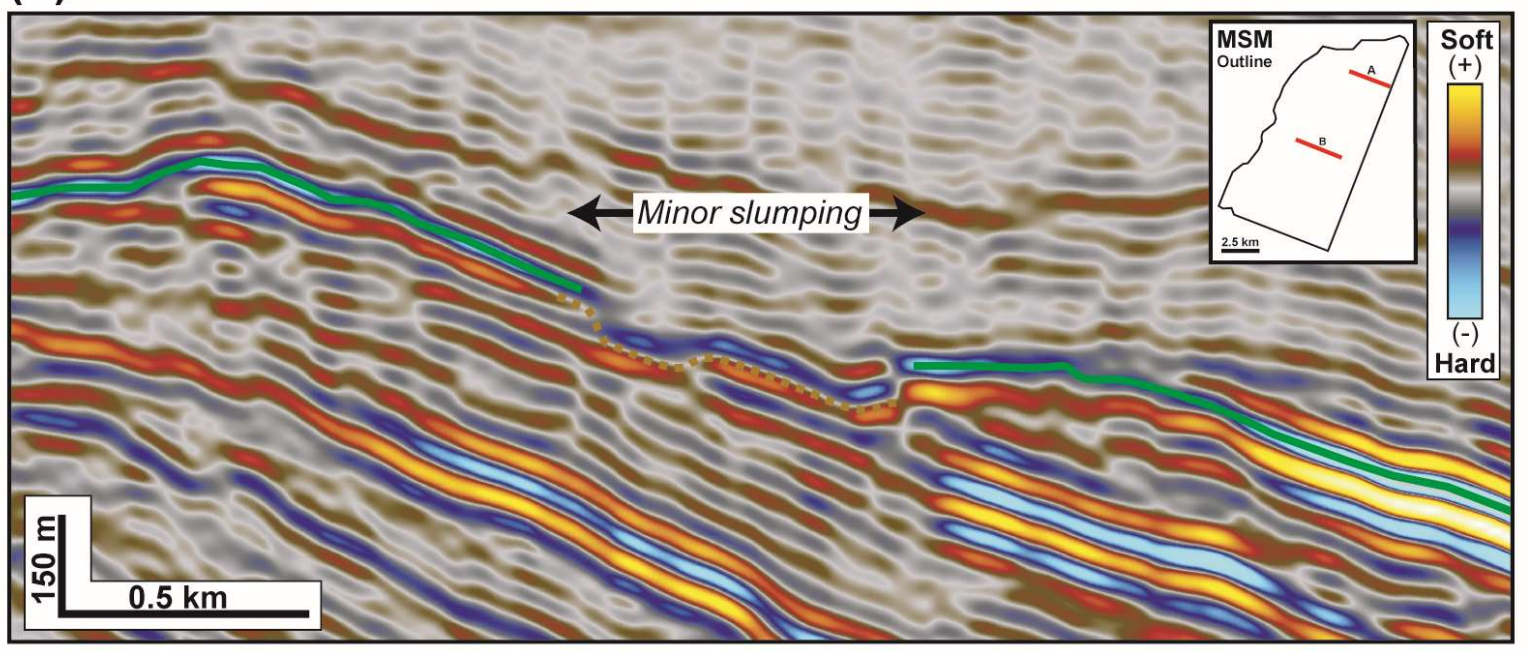

Fig.17: (a) northern dip-orientated seismic section of slumping within the upper reservoir, with extensional slump faults detaching into the MSB, (b) southern dip-orientated seismic section with minor incision and slumping. Note slump faults displace the $B C U$. 

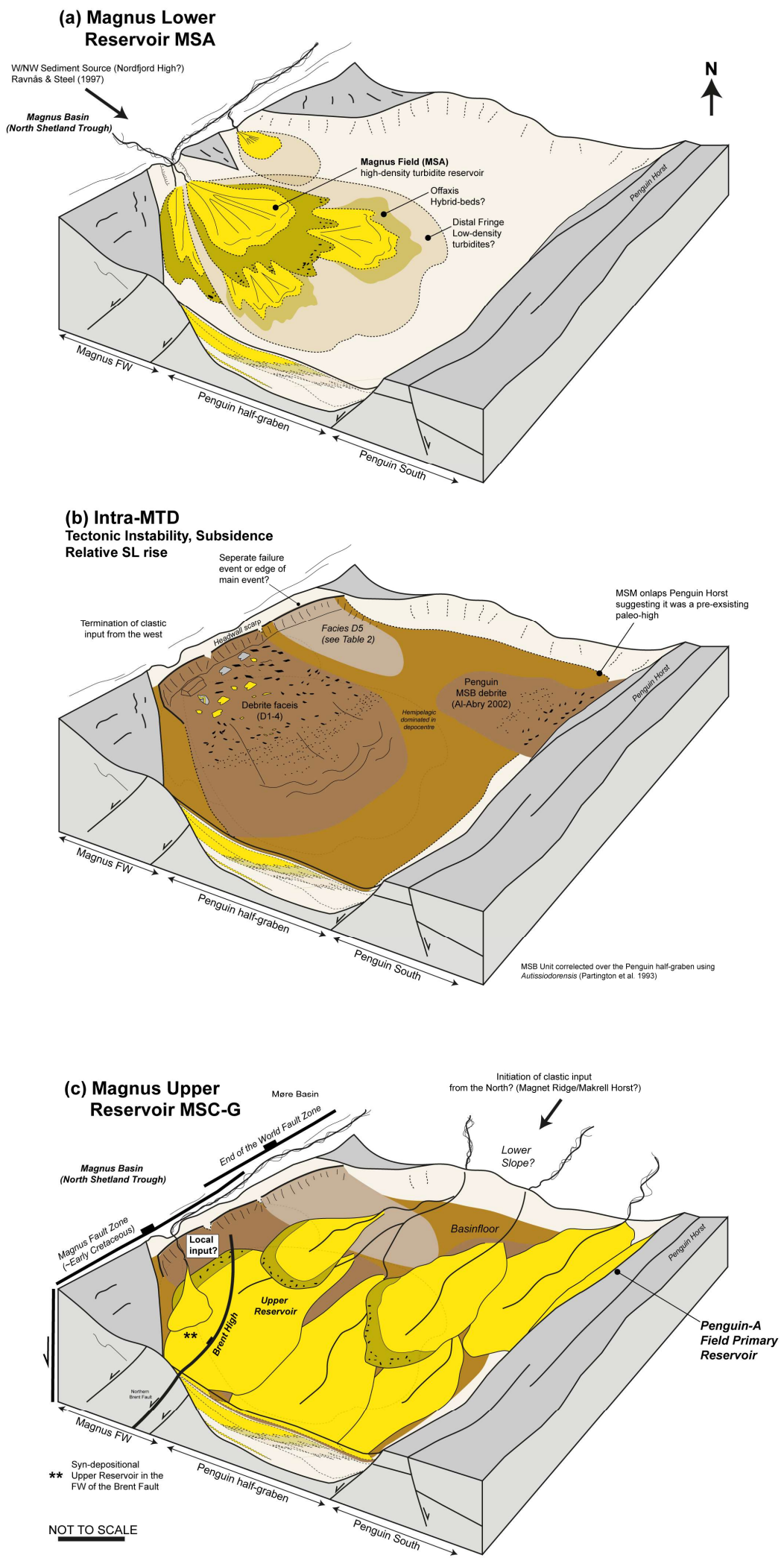

Fig. 18: Basin evolution of the Penguin half-graben, (a) Lower reservoir point sourced from the north-west, (b) Intra-reservoir MTD composed of debris flow from both the Magnus and Penguin Horsts, (c) Upper reservoir inferred to be sourced from the north-east, with a local input point transporting sediment into the hanging-wall of the Brent Fault. 

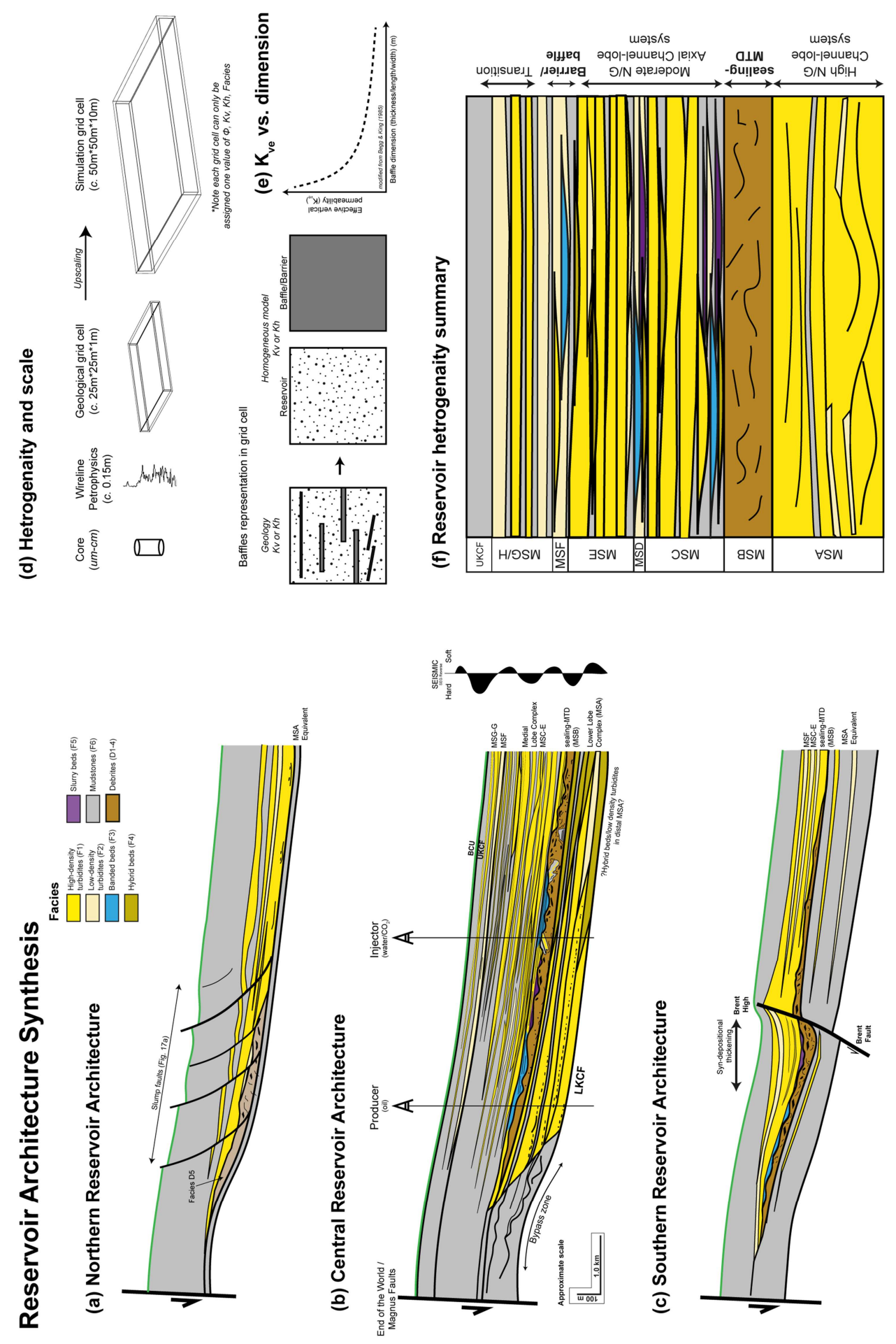

Fig. 19: Synthesis of lateral variability in reservoir architecture (a-c) idealised cross-sections of the northern, central, and southern reservoir architectures, (d/e) highlighting the difficulty of capturing core-scale heterogeneity in geological and simulation grid scale reservoir models, with a grid cell only able to represent a single value for porosity and permeability, with effective vertical permeability vs. baffle dimension showing the importance of understanding baffle dimension (modified from Begg \& King 1985), (f) summary of reservoir heterogeneity within the Magnus Field. 
Table 0-1: Summary of reservoir sedimentology in the Magnus Sandstone Member (MSM).

\begin{tabular}{|c|c|c|c|c|c|}
\hline Facies & Lithology & $\begin{array}{l}\text { Thickness } \\
\text { (m) }\end{array}$ & Sedimentology & Interpretation & $\begin{array}{c}\text { Reservoir Unit } \\
\text { (approx. } \Phi, \text { Kv, Kh, } \\
\text { VSH, Facies } \\
\text { proportions \%) } \\
\end{array}$ \\
\hline $\begin{array}{l}\text { Thick-bedded } \\
\text { sandstones (F1) }\end{array}$ & $\begin{array}{l}\text { Fine-coarse grained } \\
\text { sandstone, infrequent fine } \\
\text { sandstone/siltstone caps }\end{array}$ & $\begin{array}{c}0.2->1.0 \\
\text { (amalgamated) }\end{array}$ & $\begin{array}{l}\text { Massive or planar laminated sandstone, subtle } \\
\text { normal grading, dewatering pipes/dishes, flame } \\
\text { and load structures, with common bed } \\
\text { amalgamation. Floating mudclast-rich horizons } \\
\text { with sheared fabrics distributed throughout. } \\
\text { Rarely preserved fine sand-silt grade ripple } \\
\text { laminated bed tops. }\end{array}$ & $\begin{array}{l}\text { Process: High-density turbidity } \\
\text { currents (see Lowe 1982; } \\
\text { Shanmugam 1996), } \\
\text { Environment: forming in an } \\
\text { axial submarine lobe position }\end{array}$ & $\begin{array}{l}\text { Primary reservoir } \\
\text { MSA \& MSC-G } \\
\text { Core } \Phi=22 \% \\
\text { Log } \Phi=29 \% \\
\mathrm{Kv}=500 \mathrm{mD} \\
\mathrm{Kh}=600 \mathrm{mD} \\
\mathrm{Kv} / \mathrm{Kh}=0.83 \\
\text { Log VSH }=<1 \%\end{array}$ \\
\hline $\begin{array}{l}\text { Basal } \\
\text { sandstones (F1) }\end{array}$ & $\begin{array}{l}\text { Medium sand to granule } \\
\text { grade sandstones }\end{array}$ & $<0.05-0.25$ & $\begin{array}{l}\text { Sandstones, with weak to irregular grading, } \\
\text { imbrication of granule/pebble material, and } \\
\text { incisional/erosive bed bases }\end{array}$ & $\begin{array}{l}\text { Process: tractional carpets at } \\
\text { base of turbidity flow, } \\
\text { Environment: basal lag deposit } \\
\text { of submarine channel or bypass } \\
\text { surface from the passage of } \\
\text { turbidity currents (Walker } \\
\text { 1984) }\end{array}$ & $\begin{array}{l}\text { MSA \& MSC-G } \\
\log \Phi=26 \% \\
\text { VSH }=3 \%\end{array}$ \\
\hline $\begin{array}{l}\text { Thin-bedded } \\
\text { sandstones (F2) }\end{array}$ & $\begin{array}{l}\text { VF-Fine grained } \\
\text { sandstone and siltstone, } \\
\text { with mudstone caps }\end{array}$ & $<0.05-0.2$ & $\begin{array}{l}\text { Current ripple laminated sandstones, occasional } \\
\text { flame and load or shear fabric structures at the } \\
\text { base }\left(T_{C}\right) \text {. Sharp normal grading from sandstone } \\
\text { to silt and mudstones }\left(T_{D / E}\right) \text {. }\end{array}$ & $\begin{array}{l}\text { Process: Low-density turbidity } \\
\text { currents (Mutti 1977), } \\
\text { Environment: forming in an } \\
\text { off-axis, submarine lobe and/or } \\
\text { channel position (Jobe et al. } \\
\text { 2012). }\end{array}$ & $\begin{array}{l}\text { MSC-G } \\
\text { Core } \Phi=22 \% \\
\log \Phi=15 \% \\
\text { Kv }=400 \mathrm{mD} \\
\text { Kh }=575 \mathrm{mD} \\
\log \text { VSH }=7-14 \%\end{array}$ \\
\hline $\begin{array}{l}\text { Banded beds } \\
\text { (F3) }\end{array}$ & $\begin{array}{l}\text { Couplets of VF-Fine } \\
\text { grained sandstone and } \\
\text { siltstone, with mud-rich } \\
\text { sandstones }\end{array}$ & $<0.05-0.35$ & $\begin{array}{l}\text { Distinctive alternating light/dark banding } \\
\text { couplets. Light bands are often planar or ripple- } \\
\text { cross laminated, sand-silt, upper contacts are } \\
\text { either sharp or gradational, foundering structures } \\
\text { common at base. Dark bands have elevated } \\
\text { amounts of mudstone. }\end{array}$ & $\begin{array}{l}\text { Process: Transitional flows, } \\
\text { alternating between turbulent } \\
\text { and laminar flows (Lowe \& } \\
\text { Guy 2000), Environment: } \\
\text { submarine lobe sourced from } \\
\text { and/or depositing on mud-rich } \\
\text { substrate (Stevenson et al. } \\
\text { 2020). }\end{array}$ & $\begin{array}{l}\text { MSC-G } \\
\text { Core } \Phi=20 \\
\text { Log } \Phi=<1-24 \% \\
\text { Kv }=0.27 \mathrm{mD} \\
\text { Kh }=21 \mathrm{mD} \\
\text { Log VSH }=0-24 \%\end{array}$ \\
\hline $\begin{array}{l}\text { Hybrid beds } \\
\text { (F4) }\end{array}$ & $\begin{array}{l}\text { Fine-medium sandstones } \\
\text { and mud-rich sandstones }\end{array}$ & $0.15-0.4$ & $\begin{array}{l}\text { Lower sandstone beds graded or ungraded with } \\
\text { loading structures at base }(\mathrm{H} 1) \text {, dewatering } \\
\text { pipes, and isolated mudclasts/chips at bed top. }\end{array}$ & $\begin{array}{l}\text { Process: Hybrid event } \\
\text { beds/linked debrites, } \\
\text { transformation from turbulent }\end{array}$ & $\begin{array}{l}\text { MSC-G }(\mathrm{H} 1 \& \text { H3 }) \\
\text { Core } \Phi=20 \& 9 \% \\
\text { Log } \Phi=0.23 \%\end{array}$ \\
\hline
\end{tabular}




\begin{tabular}{|c|c|c|c|c|c|}
\hline & & & $\begin{array}{l}\text { Weakly laminated sandstone or banded bed } \\
\text { divisions (H2). Sharp or sharp foundered contact } \\
\text { into mud-rich sandstone with debritic texture, } \\
\text { sand injections, outsized clasts, with sheared } \\
\text { mud-stone clasts at the top of the bed (H3). } \\
\text { Sharp irregular contact into parallel/ripple cross } \\
\text { laminated fine sandstone and silt (H4). Sharp } \\
\text { irregular contact into massive mudstone (H5). }\end{array}$ & $\begin{array}{l}\text { to laminar flows (Haughton et } \\
\text { al. 2003; Talling et al. 2004; } \\
\text { Haughton et al. 2009), } \\
\text { Environment: predominantly in } \\
\text { distal/fringe submarine lobe } \\
\text { positions (Hodgson 2009) }\end{array}$ & $\begin{array}{l}\mathrm{Kv}=\mathrm{n} / \mathrm{a} \\
\mathrm{Kh}=200,10 \mathrm{mD} \\
\log \mathrm{VSH}=<1 \%\end{array}$ \\
\hline Slurry beds (F5) & $\begin{array}{l}\text { Fine grained sandstone, } \\
\text { siltstones, and mud-rich } \\
\text { sandstone }\end{array}$ & $0.25-0.7$ & $\begin{array}{l}\text { Sheared and folded internal fabrics, ball and } \\
\text { pillow structures, relic banded bed (F5) } \\
\text { sequences, highly shear mud clasts. Commonly } \\
\text { occur in the same sequence as Banded beds (F5). }\end{array}$ & $\begin{array}{l}\text { Process: Transitional flows, } \\
\text { (Lowe \& Guy (2000), with } \\
\text { potential for post-depositional } \\
\text { remobilisation (Barker et al. } \\
\text { 2008), Environment: submarine } \\
\text { lobe sourced from and/or } \\
\text { depositing on mud-rich } \\
\text { substrate }\end{array}$ & \\
\hline Mudstones (F6) & Mudstone to siltstone & $0.02->1.0$ & $\begin{array}{l}\text { Homogeneous mudstones and/or finely (mm- } \\
\text { scale) parallel laminated mudstones and } \\
\text { siltstones. Contacts are usually sharp. }\end{array}$ & $\begin{array}{l}\text { Process: hemipelagic settling } \\
\text { and/or mud-rich turbidity } \\
\text { currents (Stow \& Shanmugam } \\
\text { 1980; Boulesteix et al. 2019), } \\
\text { Environment: slope and } \\
\text { basinfloor }\end{array}$ & $\begin{array}{l}\text { MSA-MSG } \\
\log \Phi=0 \% \\
\text { VSH }=90+\%\end{array}$ \\
\hline $\begin{array}{l}\text { Heterogeneous } \\
\text { argillaceous } \\
\text { beds (MSB) } \\
\text { (see Table 6-2) } \\
\text { (F7) }\end{array}$ & $\begin{array}{l}\text { Chaotic Mud-rich } \\
\text { sandstones, siltstones, and } \\
\text { mudstones }\end{array}$ & $\begin{array}{l}1-18 \\
\text { (assuming a } \\
\text { single event) }\end{array}$ & $\begin{array}{l}\text { Poorly sorted mud-silt-sand matrix, with varying } \\
\text { degrees of clay content from very dark } \\
\text { grey/black }(>50 \%) \text {, to light }(<25 \%) \text {, matrix } \\
\text { contains floating fine-medium sand-grade } \\
\text { quartz, along with some granule to pebble grade } \\
\text { clasts, producing a "starry night texture'. } \\
\text { Structures include, sheared fabrics and mudstone } \\
\text { clasts, injectites, soft-sediment deformation, } \\
\text { micro-faulting, and irregular contacts with } \\
\text { undeformed blocks of intact stratigraphy. }\end{array}$ & $\begin{array}{l}\text { Process: mass-transport } \\
\text { processes initiated from slope } \\
\text { instability, predominately "well } \\
\text { mixed" cohesive debris flows } \\
\text { (Barker et al. 2008; } \\
\text { Eggenhuisen et al. 2010), } \\
\text { Environment: unstable } \\
\text { submarine slope }\end{array}$ & $\begin{array}{l}\text { MSB \& F } \\
\text { QEMSCAN } \Phi=7 \% \\
\log \Phi=6 \% \\
\text { Kv }=\text { n/a } \\
\text { Kh }=\text { n/a } \\
\log \text { VSH }=60 \%\end{array}$ \\
\hline
\end{tabular}


Table 0-2: Summary of debrite (Facies 7) sedimentology

\begin{tabular}{|l|l|l|}
\hline \multicolumn{1}{|c|}{ Sub-facies } & \multicolumn{1}{|c|}{ Sedimentological character } & \multicolumn{1}{|c|}{ Process Interpretation } \\
\hline $\begin{array}{l}\text { Sand-rich } \\
\text { debrite (D1) }\end{array}$ & $\begin{array}{l}\text { Matrix supported mud-rich sandstones, with coarse } \\
\text { sand to granule grade predominantly quartz making } \\
\text { up the grains, with minor amounts of mudstone } \\
\text { (clasts and sheared fabrics). Bed bases are } \\
\text { occasionally grain supported. Sandstone and } \\
\text { mudstone clasts are angular and often sheared. }\end{array}$ & $\begin{array}{l}\text { Process: poorly cohesive debris } \\
\text { flow, with sufficient yield strength } \\
\text { to support } ~ 0.5 \text { m clasts, } \\
\text { Environment: upper to mid slope. }\end{array}$ \\
\hline $\begin{array}{l}\text { Mud-rich } \\
\text { debrites (D2-4) }\end{array}$ & $\begin{array}{l}\text { Matrix supported mud-rich sandstones, with floating } \\
\text { quartz clasts, and varying degrees of clay content. } \\
\text { Intercalation of clasts and bedded sequences are } \\
\text { common with varying degrees of disaggregation } \\
\text { from minor soft sediment deformation to clast rich } \\
\text { debrites. Often recognisable by "starry night" } \\
\text { texture. }\end{array}$ & $\begin{array}{l}\text { Process: cohesive debris flow (see } \\
\text { Talling et al. 2014, M-2, 100+ Pa } \\
\text { yield strength), with enough } \\
\text { strength to support 1+ m clasts, } \\
\text { Environment: slope and base-of- } \\
\text { slope in main MSA lobe complex } \\
\text { depositional fairway }\end{array}$ \\
\hline $\begin{array}{l}\text { Facies (D5) } \\
\text { injectite/breccia }\end{array}$ & $\begin{array}{l}\text { Chaotic mix of mudstone-sandstone breccias, } \\
\text { sandstones, and mudstones. Structures include soft } \\
\text { sediment deformation and injection fabrics. }\end{array}$ & $\begin{array}{l}\text { Satur \& Hurst 2007), Environment: } \\
\text { off-axis of initial MSA depositional } \\
\text { fairway. }\end{array}$ \\
\hline $\begin{array}{l}\text { Process: hydraulic fracturing, } \\
\text { anjection, and minor slumping (e.g. }\end{array}$
\end{tabular}




\section{REFERENCES}

Al-Abry, N.S. 2002. Role of syn-sedimentary faulting in controlling deep water depositional systems: Upper Jurassic Magnus Sandstone Member, Northern North Sea. University of Edinburgh.

Algar, S., Milton, C., Upshall, H. \& Crevello, P. 2011. Mass-transport deposits of the deepwater Northwestern Borneo Margin - Characteization from seismic-reflection, borehole, and core data with implications for hydrocarbon exploration and exploitation. Sedimentary Geology.

Alves, T.M., Kurtev, K., Moore, G.F. \& Strasser, M. 2014. Assessing the internal character, reservoir potential, and seal competence of mass-transport deposits using seismic texture: A geophysical and petrophysical approach. AAPG Bulletin, 98, 793-824.

Amy, L.A., Peachey, S.A., Gardiner, A.A. \& Talling, P.J. 2009. Prediction of hydrocarbon recovery from turbidite sandstones with linked-debrite facies: Numerical flow-simulation studies. Marine and Petroleum Geology, 26, 2032-2043.

Armitage, D.A., Romans, B.W., Covault, J.A. \& Graham, S.A. 2009. The influence of mass-transportdeposit surface topography on the evolution of turbidite architecture: The Sierra Contreras, Tres Pasos Formation (Cretaceous), southern Chile. Journal of Sedimentary Research, 79, 287-301.

Atkinson, J. 1985. The use of reservoir engineering in the development of the Magnus oil reservoir. Offshore Europe. Society of Petroleum Engineers.

Auchter, N.C., Romans, B.W. \& Hubbard, S.M. 2016. Influence of deposit architecture on intrastratal deformation, slope deposits of the Tres Pasos Formation, Chile. Sedimentary Geology, 341, 13-26.

Avseth, P. 2000. Combining rock physics and sedimentology for seismic reservoir characterization of North Sea turbidite systems. Stanford University.

Baas, J.H., Best, J.L. \& Peakall, J. 2011. Depositional processes, bedform development and hybrid bed formation in rapidly decelerated cohesive (mud-sand) sediment flows. Sedimentology, 58, 1953-1987.

Baas, J.H., Manica, R., Puhl, E. \& de Oliveira Borges, A.L. 2016. Thresholds of intrabed flow and other interactions of turbidity currents with soft muddy substrates. Sedimentology, 63, 2002-2036.

Badley, M., Price, J., Dahl, C.R. \& Agdestein, T. 1988. The structural evolution of the northern Viking Graben and its bearing upon extensional modes of basin formation. Journal of the Geological Society, 145, 455-472.

Badley, M.E., Egeberg, T. \& Nipen, O. 1984. Development of rift basins illustrated by the structural evolution of the Oseberg feature, Block 30/6, offshore Norway. Journal of the Geological Society, 141, 639-649. 
Barker, S.P., Haughton, P.D., McCaffrey, W.D., Archer, S.G. \& Hakes, B. 2008. Development of rheological heterogeneity in clay-rich high-density turbidity currents: Aptian Britannia Sandstone Member, UK continental shelf. Journal of Sedimentary Research, 78, 45-68.

Beaubouef, R. \& Friedmann, S. 2000. High resolution seismic/sequence stratigraphic framework for the evolution of Pleistocene intra slope basins, western Gulf of Mexico: depositional models and reservoir analogs. Deep-water reservoirs of the world: Gulf Coast Section SEPM 20th Annual Research Conference, 40-60.

Beaubouef, R. \& Abreu, V. 2010. MTCs of the Brazos-Trinity slope system; thoughts on the sequence stratigraphy of MTCs and their possible roles in shaping hydrocarbon traps Submarine Mass Movements and Their Consequences. Springer, 475-490.

Begg, S. \& King, P. 1985. Modelling the effects of shales on reservoir performance: calculation of effective vertical permeability. SPE Reservoir Simulation Symposium. Society of Petroleum Engineers.

Bell, D., Stevenson, C.J., Kane, I.A., Hodgson, D.M. \& Poyatos-Moré, M. 2018. Topographic Controls On the Development of Contemporaneous but Contrasting Basin-Floor Depositional Architectures. Journal of Sedimentary Research, 88, 1166-1189.

Berndt, C., Bünz, S. \& Mienert, J. 2003. Polygonal fault systems on the mid-Norwegian margin: a longterm source for fluid flow. Geological Society, London, Special Publications, 216, 283-290.

Berndt, C., Costa, S., Canals, M., Camerlenghi, A., de Mol, B. \& Saunders, M. 2012. Repeated slope failure linked to fluid migration: the Ana submarine landslide complex, Eivissa Channel, Western Mediterranean Sea. Earth and Planetary Science Letters, 319, 65-74.

Boulesteix, K., Poyatos-Moré, M., Flint, S.S., Hodgson, D.M., Taylor, K.G. \& Parry, G.R. 2019. Sedimentary facies and stratigraphic architecture of deep-water mudstones beyond the basin-floor fan sandstone pinchout.

Bouma, A. 1964. Turbidites. Developments in sedimentology, 3, 247-256.

Bull, S., Cartwright, J. \& Huuse, M. 2009. A review of kinematic indicators from mass-transport complexes using 3D seismic data. Marine and Petroleum Geology, 26, 1132-1151.

Bünz, S., Mienert, J. \& Berndt, C. 2003. Geological controls on the Storegga gas-hydrate system of the mid-Norwegian continental margin. Earth and Planetary Science Letters, 209, 291-307.

Butler, R.W., Eggenhuisen, J.T., Haughton, P. \& McCaffrey, W.D. 2016. Interpreting syndepositional sediment remobilization and deformation beneath submarine gravity flows; a kinematic boundary layer approach. Journal of the Geological Society of London, 173, 46-58.

Cardona, S., Wood, L.J., Day-Stirrat, R.J. \& Moscardelli, L. 2016. Fabric development and pore-throat reduction in a mass-transport deposit in the Jubilee Gas Field, Eastern Gulf of Mexico: consequences for the sealing capacity of MTDs Submarine Mass Movements and their Consequences. Springer, 2737. 
Cobain, S.L., Hodgson, D.M., Peakall, J. \& Shiers, M.N. 2017. An integrated model of clastic injectites and basin floor lobe complexes: implications for stratigraphic trap plays. Basin Research, 29, 816-835.

Coleman, J. \& Prior, D.B. 1988. Mass wasting on continental margins. Annual Review of Earth and Planetary Sciences, 16, 101-119.

Cook, A.E. \& Sawyer, D.E. 2015. The mud-sand crossover on marine seismic data. Geophysics, 80, A109-A114.

Davis, C., Haughton, P., McCaffrey, W., Scott, E., Hogg, N. \& Kitching, D. 2009. Character and distribution of hybrid sediment gravity flow deposits from the outer Forties Fan, Palaeocene Central North Sea, UKCS. Marine and Petroleum Geology, 26, 1919-1939.

Day-Stirrat, R.J., Flemings, P.B., You, Y. \& van der Pluijm, B.A. 2013. Modification of mudstone fabric and pore structure as a result of slope failure: Ursa Basin, Gulf of Mexico. Marine Geology, 341, 58-67.

De'Ath, N., DE'ATH, N. \& SF, S. 1981. The geology of the Magnus oilfield.

Dodd, T.J., McCarthy, D.J. \& Clarke, S.M. 2019. Clastic injectites, internal structures and flow regime during injection: the Sea Lion Injectite System, North Falkland Basin. Sedimentology.

Dominguez, R. 2007. Structural evolution of the Penguins cluster, UK northern North Sea. Geological Society, London, Special Publications, 292, 25-48.

Dott, R. 1963. Dynamics of subaqueous gravity depositional processes. American Association of Petroleum Geologists (AAPG) Bulletin, 47, 104-128.

Downey, M.W. 1984. Evaluating seals for hydrocarbon accumulations. AAPG Bulletin, 68, 1752-1763.

Drinkwater, N. \& Pickering, K. 2001. Architectural elements in a high-continuity sand-prone turbidite system, late Precambrian Kongsfjord Formation, northern Norway: Application to hydrocarbon reservoir characterization. AAPG Bulletin, 85, 1731-1757.

Dugan, B. 2012. Petrophysical and consolidation behavior of mass transport deposits from the northern Gulf of Mexico, IODP Expedition 308. Marine Geology, 315, 98-107.

Dykstra, M., Garyfalou, K., Kertznus, V., Kneller, B., Milana, J.P., Molinaro, M., Szuman, M. \& Thompson, P. 2011. Mass-transport deposits: combining outcrop studies and seismic forward modeling to understand lithofacies distributions, deformation, and their seismic expression. SEPM Special Publication, 96, 293-310.

Eggenhuisen, J., McCaffrey, W., Haughton, P., Butler, R., Moore, I., Jarvie, A. \& Hakes, W. 2010. Reconstructing large-scale remobilisation of deep-water deposits and its impact on sand-body 
architecture from cored wells: The Lower Cretaceous Britannia Sandstone Formation, UK North Sea. Marine and Petroleum Geology, 27, 1595-1615.

Fisher, R.V. 1983. Flow transformations in sediment gravity flows. Geology, 11, 273-274.

Flemings, P., Long, H., Dugan, B., Germaine, J., John, C., Behrmann, J.H., Sawyer, D. \& Expedition, I. 2008. Pore pressure penetrometers document high overpressure near the seafloor where multiple submarine landslides have occurred on the continental slope, offshore Louisiana, Gulf of Mexico. Earth and Planetary Science Letters, 269, 309-325.

Flint, S.S., Hodgson, D.M., Sixsmith, P.J., Grecula, M. \& Wickens, H.D.V. 2007. Karoo Basin, South Africa: Deep-water Basin-floor and Slope Deposits of the Laingsburg Depocenter.

Fonnesu, M., Haughton, P., Felletti, F. \& McCaffrey, W. 2015. Short length-scale variability of hybrid event beds and its applied significance. Marine and Petroleum Geology, 67, 583-603.

Fonnesu, M., Felletti, F., Haughton, P.D., Patacci, M. \& McCaffrey, W.D. 2018. Hybrid event bed character and distribution linked to turbidite system sub-environments: The North Apennine Gottero Sandstone (north-west Italy). Sedimentology, 65, 151-190.

Gabrielsen, R., Odinsen, T. \& Grunnaleite, I. 1999. Structuring of the Northern Viking Graben and the Møre Basin; the influence of basement structural grain, and the particular role of the Møre-Trøndelag Fault Complex. Marine and Petroleum Geology, 16, 443-465.

Galloway, W.E. 1998. Siliciclastic slope and base-of-slope depositional systems: component facies, stratigraphic architecture, and classification. American Association of Petroleum Geologists (AAPG) bulletin, 82, 569-595.

Gamboa, D. \& Alves, T.M. 2015. Three-dimensional fault meshes and multi-layer shear in masstransport blocks: Implications for fluid flow on continental margins. Tectonophysics, 647, 21-32.

Garland, C., Haughton, P., King, R. \& Moulds, T. 1999. Capturing reservoir heterogeneity in a sandrich submarine fan, Miller Field. Geological Society, London, Petroleum Geology Conference series. Geological Society of London, 1199-1208.

Goodall, I., Lofts, J., Mulcahy, M., Ashton, M. \& Johnson, S. 1999. A sedimentological application of ultrasonic borehole images in complex lithologies: the Lower Kimmeridge Clay Formation, Magnus Field, UKCS. Geological Society, London, Special Publications, 159, 203-225.

Gottlieb, P., Wilkie, G., Sutherland, D., Ho-Tun, E., Suthers, S., Perera, K., Jenkins, B., Spencer, S., et al. 2000. Using quantitative electron microscopy for process mineralogy applications. Jom, 52, 24-25.

Grecula, M., Kattah, S., Akinsanmi, O., Uy, H., Hedeir, K., Osterloff, P., Maguire, K., Shiner, P., et al. 2008. Prediction of Reservoir Distribution and Quality in Tectonically Active NW Borneo Slope. IPTC 2008: International Petroleum Technology Conference. European Association of Geoscientists \& Engineers, cp-148-00149. 
Hampton, M. 1975. Competence of fine-grained debris flows. Journal of Sedimentary Research, 45, 834-844.

Hansen, L., Janocko, M., Kane, I. \& Kneller, B. 2017. Submarine channel evolution, terrace development, and preservation of intra-channel thin-bedded turbidites: Mahin and Avon channels, offshore Nigeria. Marine Geology, 383, 146-167.

Haughton, P., Davis, C., McCaffrey, W. \& Barker, S. 2009. Hybrid sediment gravity flow depositsclassification, origin and significance. Marine and Petroleum Geology, 26, 1900-1918.

Haughton, P.D., Barker, S.P. \& McCaffrey, W.D. 2003. 'Linked'debrites in sand-rich turbidite systems-origin and significance. Sedimentology, 50, 459-482.

Hodgson, D.M. 2009. Distribution and origin of hybrid beds in sand-rich submarine fans of the Tanqua depocentre, Karoo Basin, South Africa. Marine and Petroleum Geology, 26, 1940-1956.

Hurst, A. \& Cartwright, J. 2007. Relevance of sand injectites to hydrocarbon exploration and production.

Jackson, C.A. \& Johnson, H.D. 2009. Sustained turbidity currents and their interaction with debriterelated topography; Labuan Island, offshore NW Borneo, Malaysia. Sedimentary Geology, 219, 77-96.

Jackson, M. \& Muggeridge, A. 2000. Effect of discontinuous shales on reservoir performance during horizontal waterflooding. SPE Journal, 5, 446-455.

Jackson, M., Hampson, G., Saunders, J., El-Sheikh, A., Graham, G. \& Massart, B. 2014. Surface-based reservoir modelling for flow simulation. Geological Society, London, Special Publications, 387, 271292.

Jacquemyn, C., Jackson, M.D. \& Hampson, G.J. 2019. Surface-based geological reservoir modelling using grid-free NURBS curves and surfaces. Mathematical Geosciences, 51, 1-28.

Jennette, D.C., Garfield, T.R., Mohrig, D.C. \& Cayley, G.T. 2000. The interaction of shelf accommodation, sediment supply and sea level in controlling the facies, architecture and sequence stacking patterns of the Tay and Forties/Sele basin-floor fans, Central North Sea. Deep-Water Reservoirs of the World. GCSSEPM Foundation 20th Annual Research Conference Proceedings, 3-6.

Jobe, Z.R., Lowe, D.R. \& Morris, W.R. 2012. Climbing-ripple successions in turbidite systems: depositional environments, sedimentation rates and accumulation times. Sedimentology, 59, 867-898.

Johns, C.R. \& Andrews, I.J. 1985. The petroleum geology of the Unst Basin, North Sea. Marine and Petroleum Geology, 2, 361-372.

Kaldi, J. \& Atkinson, C. 1997. Evaluating seal potential: example from the Talang Akar Formation, offshore northwest Java, Indonesia. Memoirs, American Association of Petroleum Geologist, 85-102. 
Kane, I.A., Pontén, A.S., Vangdal, B., Eggenhuisen, J.T., Hodgson, D.M. \& Spychala, Y.T. 2017. The stratigraphic record and processes of turbidity current transformation across deep-marine lobes. Sedimentology.

Kendrick, J. 1998. Turbidite reservoir architecture in the Gulf of Mexico-insights from field development. EAGE/AAPG 3rd Research Symposium-Developing and Managing Turbidite Reservoirs. European Association of Geoscientists \& Engineers, cp-100-00003.

Kendrick, J.W. 2000. Turbidite Reservoir Architecture in the Northern Gulf of Mexico Deepwater: Insights from the Development of Auger, Tahoe, and Ram/Powell Fields. In: Weimer, P. (ed) DeepWater Reservoirs of the World. SEPM Society for Sedimentary Geology.

Kneller, B., Dykstra, M., Fairweather, L. \& Milana, J.P. 2016. Mass-transport and slope accommodation: implications for turbidite sandstone reservoirs. AAPG Bulletin, 100, 213-235.

Kneller, B.C. \& Branney, M.J. 1995. Sustained high-density turbidity currents and the deposition of thick massive sands. Sedimentology, 42, 607-616.

Koša, E. 2007. Differential subsidence driving the formation of mounded stratigraphy in deep-water sediments; Palaeocene, central North Sea. Marine and Petroleum Geology, 24, 632-652.

Lake, L.W. 1989. Enhanced oil recovery.

Lancaster, S. \& Whitcombe, D. 2000. Fast-track 'coloured'inversion SEG Technical Program Expanded Abstracts 2000. Society of Exploration Geophysicists, 1572-1575.

Lee, M. \& Hwang, Y. 1993. Tectonic evolution and structural styles of the East Shetland Basin. Geological Society, London, Petroleum Geology Conference series. Geological Society of London, 1137-1149.

Lowe, D., Guy, M. \& Palfrey, A. 2003. Facies of slurry-flow deposits, Britannia Formation (Lower Cretaceous), North Sea: implications for flow evolution and deposit geometry. Sedimentology, 50, 4580 .

Lowe, D.R. 1982. Sediment gravity flows: II Depositional models with special reference to the deposits of high-density turbidity currents. Journal of Sedimentary Research, $\mathbf{5 2}$.

Lowe, D.R. \& Guy, M. 2000. Slurry-flow deposits in the Britannia Formation (Lower Cretaceous), North Sea: a new perspective on the turbidity current and debris flow problem. Sedimentology, 47, 3170.

MacGregor, A., Trussell, P., Lauver, S., Bedrock, M., Bryce, J. \& Moulds, T. 2005. The Magnus Field: extending field life through good reservoir management and enhanced oil recovery. Geological Society, London, Petroleum Geology Conference series. Geological Society of London, 469-475. 
Mattern, F. 2005. Ancient sand-rich submarine fans: depositional systems, models, identification, and analysis. Earth-Science Reviews, 70, 167-202.

Mayall, M., Yeilding, C., Oldroyd, J., Pulham, A. \& Sakurai, S. 1992. Facies in a Shelf-Edge Delta-An Example from the Subsurface of the Gulf of Mexico, Middle Pliocene, Mississippi Canyon, Block 109 (1). American Association of Petroleum Geologists (AAPG) bulletin, 76, 435-448.

McCaffrey, W. \& Kneller, B. 2001. Process controls on the development of stratigraphic trap potential on the margins of confined turbidite systems and aids to reservoir evaluation. AAPG Bulletin, 85, 971988.

McLeod, A. \& Underhill, J. 1999. Processes and products of footwall degradation, northern Brent Field, Northern North Sea. Geological Society, London, Petroleum Geology Conference series. Geological Society of London, 91-106.

Meckel, L. 2011. Reservoir characteristics and classification of sand-prone submarine mass-transport deposits. SEPM Special Publication, 96, 432-452.

Melnikova, Y., Jacquemyn, C., Osman, H., Salinas, P., Gorman, G., Hampson, G. \& Jackson, M. 2016. Reservoir modelling using parametric surfaces and dynamically adaptive fully unstructured grids. ECMOR XV-15th European Conference on the Mathematics of Oil Recovery. European Association of Geoscientists \& Engineers, cp-494-00147.

Mohrig, D., Ellis, C., Parker, G., Whipple, K.X. \& Hondzo, M. 1998. Hydroplaning of subaqueous debris flows. Geological Society of America Bulletin, 110, 387-394.

Morris, P., Payne, S. \& Richards, D. 1999. Micropalaeontological biostratigraphy of the Magnus Sandstone Member (Kimmeridgian-Early Volgian), Magnus Field, UK North Sea. Geological Society, London, Special Publications, 152, 55-73.

Moscardelli, L., Wood, L. \& Mann, P. 2006. Mass-transport complexes and associated processes in the offshore area of Trinidad and Venezuela. AAPG Bulletin, 90, 1059-1088.

Mulder, T. \& Cochonat, P. 1996. Classification of offshore mass movements. Journal of Sedimentary Research, 66, 43-57.

Mutti, E. 1977. Distinctive thin-bedded turbidite facies and related depositional environments in the Eocene Hecho Group (South-central Pyrenees, Spain). Sedimentology, 24, 107-131.

Mutti, E. \& Normark, W.R. 1987. Comparing examples of modern and ancient turbidite systems: problems and concepts Marine clastic sedimentology. Springer, 1-38.

Nardin, T.R. 1979. A review of mass movement processes sediment and acoustic characteristics, and contrasts in slope and base-of-slope systems versus canyon-fan-basin floor systems. SEPM Special Publication. 
Nemec, W. 1990. Aspects of sediment movement on steep delta slopes. Special Publication, International Association of Sedimentologists, Coarse-grained deltas, 10, 29-73.

Nemec, W., Steel, R., Gjelberg, J., Collinson, J., Prestholm, E. \& Oxnevad, I. 1988. Anatomy of collapsed and re-established delta front in Lower Cretaceous of eastern Spitsbergen: gravitational sliding and sedimentation processes. American Association of Petroleum Geologists (AAPG) bulletin, 72, 454-476.

O'Connor, S. \& Walker, D. 1993. Paleocene reservoirs of the Everest trend. Geological Society, London, Petroleum Geology Conference series. Geological Society of London, 145-160.

Ortiz-Karpf, A., Hodgson, D. \& McCaffrey, W. 2015. The role of mass-transport complexes in controlling channel avulsion and the subsequent sediment dispersal patterns on an active margin: the Magdalena Fan, offshore Colombia. Marine and Petroleum Geology, 64, 58-75.

Ortiz-Karpf, A., Hodgson, D.M., Jackson, C.A.L. \& McCaffrey, W.D. 2016. Mass-transport complexes as markers of deep-water fold-and-thrust belt evolution: insights from the southern Magdalena fan, offshore Colombia. Basin Research, http://doi.org/10.1111/bre.12208.

Ortiz-Karpf, A., Hodgson, D.M., Jackson, C.A.-L. \& McCaffrey, W.D. 2017. Influence of Seabed Morphology and Substrate Composition On Mass-Transport Flow Processes and Pathways: Insights From the Magdalena Fan, Offshore Colombia. Journal of Sedimentary Research, 87, 189-209.

Osborne, M.J. \& Swarbrick, R.E. 1997. Mechanisms for generating overpressure in sedimentary basins: a reevaluation. AAPG Bulletin, 81, 1023-1041.

Partington, M., Copestake, P., Mitchener, B.a. \& Underhill, J.R. 1993. Biostratigraphic calibration of genetic stratigraphic sequences in the Jurassic-lowermost Cretaceous (Hettangian to Ryazanian) of the North Sea and adjacent areas. Geological Society, London, Petroleum Geology Conference series. Geological Society of London, 371-386.

Passey, Q.R., Dahlberg, K.E., Sullivan, K., Yin, H., Brackett, B., Xiao, Y. \& Guzman-Garcia, A.G. 2006. Petrophysical evaluation of hydrocarbon pore-thickness in thinly bedded clastic reservoirs: AAPG Archie Series, no. 1. Aapg.

Pickering, K.T. \& Corregidor, J. 2005. Mass-transport complexes (MTCs) and tectonic control on basin-floor submarine fans, middle Eocene, south Spanish Pyrenees. Journal of Sedimentary Research, 75, 761-783.

Pierce, C.S., Haughton, P.D., Shannon, P.M., Pulham, A.J., Barker, S.P. \& Martinsen, O.J. 2018. Variable character and diverse origin of hybrid event beds in a sandy submarine fan system, Pennsylvanian Ross Sandstone Formation, western Ireland. Sedimentology, 65, 952-992.

Piper, D., Pirmez, C., Manley, P., Long, D., Flood, R., Normark, W. \& Showers, W. 1997. Masstransport deposits of the Amazon Fan. 
Piper, D.J. \& Normark, W.R. 1983. Turbidite depositional patterns and flow characteristics, Navy submarine fan, California Borderland. Sedimentology, 30, 681-694.

Porten, K.W., Kane, I.A., Warchoł, M.J. \& Southern, S.J. 2016. A sedimentological process-based approach to depositional reservoir quality of deep-marine sandstones: an example from the Springar Formation, northwestern Vøring Basin, Norwegian Sea. Journal of Sedimentary Research, 86, 12691286.

Prather, B.E. 2003. Controls on reservoir distribution, architecture and stratigraphic trapping in slope settings. Marine and Petroleum Geology, 20, 529-545.

Prélat, A., Hodgson, D. \& Flint, S. 2009. Evolution, architecture and hierarchy of distributary deepwater deposits: a high-resolution outcrop investigation from the Permian Karoo Basin, South Africa. Sedimentology, 56, 2132-2154.

Prélat, A., Hodgson, D.M., Hall, M., Jackson, C.A.-L., Baunack, C. \& Tveiten, B. 2015. Constraining sub-seismic deep-water stratal elements with electrofacies analysis; A case study from the Upper Cretaceous of the Måløy Slope, offshore Norway. Marine and Petroleum Geology, 59, 268-285.

Pyles, D.R. 2007. Architectural elements in a ponded submarine fan, Carboniferous Ross Sandstone, western Ireland.

Pyles, D.R. \& Jennette, D. 2009. Geometry and architectural associations of co-genetic debrite-turbidite beds in basin-margin strata, Carboniferous Ross Sandstone (Ireland): Applications to reservoirs located on the margins of structurally confined submarine fans. Marine and Petroleum Geology, 26, 1974-1996.

Ravnås, R. \& Steel, R.J. 1997. Contrasting styles of Late Jurassic syn-rift turbidite sedimentation: a comparative study of the Magnus and Oseberg areas, northern North Sea. Marine and Petroleum Geology, 14, 417-449.

Ray, F., Pinnock, S., Katamish, H. \& Turnbull, J. 2010. The Buzzard Field: anatomy of the reservoir from appraisal to production. Geological Society, London, Petroleum Geology Conference series. Geological Society of London, 369-386.

Reading, H.G. \& Richards, M. 1994. Turbidite systems in deep-water basin margins classified by grain size and feeder system. American Association of Petroleum Geologists (AAPG) bulletin, 78, 792-822.

Riboulot, V., Cattaneo, A., Sultan, N., Garziglia, S., Ker, S., Imbert, P. \& Voisset, M. 2013. Sea-level change and free gas occurrence influencing a submarine landslide and pockmark formation and distribution in deepwater Nigeria. Earth and Planetary Science Letters, 375, 78-91.

Sarkar, S., Berndt, C., Minshull, T.A., Westbrook, G.K., Klaeschen, D., Masson, D.G., Chabert, A. \& Thatcher, K.E. 2012. Seismic evidence for shallow gas-escape features associated with a retreating gas hydrate zone offshore west Svalbard. Journal of Geophysical Research: Solid Earth, 117.

Satur, N. \& Hurst, A. 2007. Sand-injection Structures in Deep-water Sandstones from the Ty Formation (Paleocene), Sleipner st Field, Norwegian North Sea. 
Sawyer, D.E., Flemings, P.B., Dugan, B. \& Germaine, J.T. 2009. Retrogressive failures recorded in mass transport deposits in the Ursa Basin, Northern Gulf of Mexico. Journal of Geophysical Research: Solid Earth, 114.

Sawyer, D.E., Flemings, P.B., Buttles, J. \& Mohrig, D. 2012. Mudflow transport behavior and deposit morphology: Role of shear stress to yield strength ratio in subaqueous experiments. Marine Geology, 307, 28-39.

Shepherd, M. 1991. The Magnus Field, Block 211/7a, 12a, UK North Sea. Geological Society, London, Memoirs, 14, 153-157.

Shepherd, M., Kearney, C. \& Milne, J. 1990. Magnus field.

Sobiesiak, M.S., Kneller, B., Alsop, G.I. \& Milana, J.P. 2018. Styles of basal interaction beneath mass transport deposits. Marine and Petroleum Geology, 98, 629-639.

Southern, S.J., Kane, I.A., Warchoł, M.J., Porten, K.W. \& McCaffrey, W.D. 2017. Hybrid event beds dominated by transitional-flow facies: character, distribution and significance in the Maastrichtian Springar Formation, north-west Vøring Basin, Norwegian Sea. Sedimentology, 64, 747-776.

Soutter, E.L., Kane, I.A., Fuhrmann, A., Cumberpatch, Z.A. \& Huuse, M. 2019. The stratigraphic evolution of onlap in siliciclastic deep-water systems: Autogenic modulation of allogenic signals. Journal of Sedimentary Research, 89, 890-917.

Spychala, Y.T., Hodgson, D.M., Stevenson, C.J. \& Flint, S.S. 2017a. Aggradational lobe fringes: The influence of subtle intrabasinal seabed topography on sediment gravity flow processes and lobe stacking patterns. Sedimentology, 64, 582-608.

Spychala, Y.T., Hodgson, D.M., Prélat, A., Kane, I.A., Flint, S.S. \& Mountney, N.P. 2017b. Frontal and lateral submarine lobe fringes: comparing sedimentary facies, architecture and flow processes. Journal of Sedimentary Research, 87, 75-96.

Stevenson, C.J., Jackson, C.A.-L., Hodgson, D.M., Hubbard, S.M. \& Eggenhuisen, J.T. 2015. Deepwater sediment bypass. Journal of Sedimentary Research, 85, 1058-1081.

Stevenson, C.J., Peakall, J., Hodgson, D., M, Bell, D. \& Privat, A. 2020. Tb or not Tb: Banding in Turbidite Sandstones. Sedimentology, In review.

Steventon, M.J., Jackson, C.A.L., Hodgson, D.M. \& Johnson, H.D. 2019. Strain analysis of a seismically imaged mass-transport complex, offshore Uruguay. Basin Research, 31, 600-620.

Stow, D. \& Piper, D. 1984. Deep-water fine-grained sediments: facies models. Geological Society, London, Special Publications, 15, 611-646. 
Strachan, L.J. 2002. Slump-initiated and controlled syndepositional sandstone remobilization: an example from the Namurian of County Clare, Ireland. Sedimentology, 49, 25-41.

Sumner, E.J., Talling, P.J. \& Amy, L.A. 2009. Deposits of flows transitional between turbidity current and debris flow. Geology, 37, 991-994.

Sun, Q. \& Alves, T. 2020. Petrophysics of fine-grained mass-transport deposits: A critical review. Journal of Asian Earth Sciences, 104291.

Sun, Q., Alves, T., Xie, X., He, J., Li, W. \& Ni, X. 2017. Free gas accumulations in basal shear zones of mass-transport deposits (Pearl River Mouth Basin, South China Sea): An important geohazard on continental slope basins. Marine and Petroleum Geology, 81, 17-32.

Talling, P., Amy, L.A., Wynn, R., Peakall, J. \& Robinson, M. 2004. Beds comprising debrite sandwiched within co-genetic turbidite: origin and widespread occurrence in distal depositional environments. Sedimentology, 51, 163-194.

Talling, P.J. 2013. Hybrid submarine flows comprising turbidity current and cohesive debris flow: Deposits, theoretical and experimental analyses, and generalized models. Geosphere, 9, 460-488.

Talling, P.J., Masson, D.G., Sumner, E.J. \& Malgesini, G. 2012. Subaqueous sediment density flows: depositional processes and deposit types. Sedimentology, 59, 1937-2003.

Tappin, D., McNeil, L., Henstock, T. \& Mosher, D. 2007. Mass wasting processes-offshore Sumatra Submarine mass movements and their consequences. Springer, 327-336.

Thomas, D. \& Coward, M. 1995. Late Jurassic-Early Cretaceous inversion of the northern East Shetland Basin, northern North Sea. Oceanographic Literature Review, 11, 982.

Tripsanas, E.K., Piper, D.J., Jenner, K.A. \& Bryant, W.R. 2008. Submarine mass-transport facies: new perspectives on flow processes from cores on the eastern North American margin. Sedimentology, 55, 97-136.

Underhill, J.R., Sawyer, M.J., Hodgson, P., Shallcross, M.D. \& Gawthorpe, R.L. 1997. Implications of fault scarp degradation for Brent Group prospectivity, Ninian Field, northern North Sea. AAPG Bulletin, 81, 999-1022.

Walker, R.G. 1985. Mudstones and thin-bedded turbidites associated with the Upper Cretaceous Wheeler Gorge conglomerates, California; a possible channel-levee complex. Journal of Sedimentary Research, 55, 279-290.

Walker, R.G. \& Mutti, E. 1973. Part IV. Turbidite facies and facies associations.

Weimer, P. 1989. Sequence stratigraphy of the Mississippi Fan (Plio-Pleistocene), Gulf of Mexico. Geo-Marine Letters, 9, 185-272. 
Welbon, A., Brockbank, P., Brunsden, D. \& Olsen, T. 2007. Characterizing and producing from reservoirs in landslides: Challenges and opportunities. Geological Society, London, Special Publications, 292, 49-74.

Wu, N., Jackson, C.A.-L., Johnson, H. \& Hodgson, D.M. 2019. Lithological, petrophysical and seal properties of mass-transport complexes (MTCs), northern Gulf of Mexico.

Yamamoto, Y. \& Sawyer, D.E. 2012. Systematic Spatial Variations in the Fabric and Physical Properties of Mass-Transport Deposits in the Ursa Region, Northern Gulf of Mexico Submarine Mass Movements and Their Consequences. Springer, 649-658.

Yielding, G. 1990. Footwall uplift associated with Late Jurassic normal faulting in the northern North Sea. Journal of the Geological Society, 147, 219-222.

Ziegler, P. 1990. Tectonic and palaeogeographic development of the North Sea rift system. Tectonic evolution of the North Sea rifts, 1-36. 